\title{
The Establishment Clause and Aid to Parochial Schools
}

\author{
Jesse H. Choper*
}

I

\section{INTRODUCTION}

TN 1947, Mr. Justice Rutledge found "[t]wo great drives . . constantly in motion to abridge ... the cornplete division of religion and civil authority which our forefathers made. One is to introduce religious education and observances into the public schools. The other, to obtain public funds for the aid and support of various private religious schools." Everson v. Board of Education, the occasion for his observation, was the first significant decision of the Supreme Court in current history interpreting the establishment clause of the first amendment. Involving bussing of children to parochial schools, it concerned the second of the Justice's "two great drives."

Since 1947, the Court has addressed itself extensively to the first of the two issues in controversy - the influence of religion in the public schools. ${ }^{2}$ Although litigation on that question continues to arise, ${ }^{3}$ the Court's pronouncements, despite some criticism, ${ }^{4}$ seem largely to have resolved the

*B.S., 1957, Wilkes College; LL.B., 1960, University of Pennsylvania ; D.Hu.Litt, 1967, Wilkes College; Professor of Law, University of California, Berkeley. The author wishes to express his gratitude to his colleague, Frank I. Goodman, for his very helpful comments and to Alan S. Koenig, of the third year class, for his excellent and exceptionally thorough research assistance.

${ }^{1}$ Everson v. Board of Educ., 330 U.S. 1, 63 (1947) (dissenting opinion). See also id. at 14 .

2 See McCollum v. Board of Educ., 333 U.S. 203 (1948) (on-premises released time); Zorach v. Clauson, 343 U.S. 306 (1952) (off-premises released time); Engel v. Vitale, 370 U.S. 421 (1962) (Regents' prayer); School Dist. v. Schempp, 374 U.S. 203 (1963) (Bible reading and Lord's Prayer).

3 See Chamberlin v. Dade County Bd. of Pub. Instruction, 377 U.S. 402 (1964) (baccalaureate services) ; DeSpain v. DeKalb, 384 F.2d 837 (7th Cir. 1967) (compulsory recitation of thankful-type verse); Stein v. Oshinsky, 348 F.2d 999 (2d Cir.), cert. denied, 382 U.S. 957 (1965); Reed v. Van Hoven, 237 F. Supp. 48 (W.D. Mich. 1965) (prayers before school begins); Lewis v. Allen, 14 N.Y.2d 867, 200 N.E.2d 767, cert. denied, 379 U.S. 923 (1964) ("under God" in pledge of allegiance). See generally Ladd, Public Education and Religion, 13 J. PuB. L. 310 (1964); Note, 20 VAND. L. Rev. 1078 (1967).

${ }^{4}$ For various views, see Brown, Quis Custodiet Ipsos Custodes?-The School Prayer Case, 1963 Sur. Cr. Rev. 1; Choper, Religion in the Public Schools: A Proposed Constitutional Standard, 47 MInN. L. REv. 329 (1963); Fordham, The Implications of the Supreme Court Decisions Dealing with Religious Practices in the Public Schools, 6 J. CHurct \& ST. 44 (1964); Griswold, Absolute is in the Dark-A Discussion of the Approach of the Supreme Court to Constitutional Questions, 8 UTAE L. Rev. 167 (1963); Kauper, Prayer, Public Schools and the Supreme Court, 61 Micr. L. REv. 1031 (1963); Kurland, The Regents' 
matter. Therefore, it is evident that the most sensitive issue involving religion and government today is, as in Everson, that of public aid to paroclial schools. ${ }^{5}$ Intense interest in the constitutional aspect of the topic is reflected in a recent pamphlet reporting that as of December 1, 1967, at least a score of cases involving the establisliment clause question were pending in state and lower federal courts. ${ }^{6}$ And, on January 15, 1968, the Supreme Court, for the first time in over twenty years, agreed to hear argument on the subject. ${ }^{7}$

\section{A. The Concept of Aid}

Forcefully empliasized and oft-repeated language in Supreme Court opinions, beginning with Everson, appears to permit little room for debate about aid to religion:

The "establislment of religion" clause of the First Amendment means at least this: Neither a state nor the Federal Government . . . can pass laws which aid one religion, aid all religions, or prefer one religion over another .... No tax in any amount, large or small, can be levied to support any religious activities or institutions, whatever they may be called, or whatever form they may adopt to teach or practice religion. ${ }^{8}$

On this basis, President John F. Kennedy declared in 1961 that a "clear prohibition of the Constitution" forbade the allocation of federal funds for parochial schools.

What constitutes aid or support, lowever, is "obviously a soplisticated and not a simple literal concept."10 In the Everson decision itself, for

Prayer Case: "Full of Sound and Fury, Signifying . . ., 1962 Sor. Cr. Rev. 1; Pollak, Foreword: Public Prayers in Public Schools, 77 HARv. I. REv. 62 (1963); Sutherland, Establishment According to Engel, 76 HaRv. I. REv. 25 (1962).

There has been virtually no disagreement with the Court's firm determination that the ban of the establishment clause extends beyond the setting up of a state church. See McGowan v. Maryland, 366 U.S. 420, 442 (1961).

5 See P. KaUper, Religion and the Constitution 109 (1964); Oaks, Introduction to The Wati between Church and State 1, 5 (D. Oaks ed. 1963).

6 American Jewrish Congress Commission on Law and Social Action, Litigation Docket of Pending Cases Affecting Freedom of Religion and Separation of Church and State, Dec. 1, 1967 , at i-ii.

7 Board of Educ. v. Allen, 20 N.Y.2d 109, 228 N.E.2d 791, 281 N.Y.S.2d 799 (1967), prob. juris. noted, 36 U.S.L.W. 3278 (U.S. Jan. 15, 1968).

8 Everson v. Board of Educ., 330 U.S. 1, 15-16 (1947); accord, Torcaso v. Watkins, 367 U.S. 488, 492-93 (1961); McGowan v. Maryland, 366 U.S. 420, 443 (1961); McCollum v. Board of Educ., 333 U.S. 203, 210 (1948). See also School Dist. v. Schempp, 374 U.S. 203, 216 (1963).

O 107 Cong. Rec. 2430 (1961).

10 Hayes, The Constitutional Permissibility of the Participation of Church-Related Schools in the Administration's Proposed Program of Massive Federal Aid to Education, 11 DE PaUL I. Rev. 161, 168 (1962). 
example, the Court upheld public reimbursement to parents for the expense of bussing their children both to public schools and to Catholic parochial schools; yet the Court acknowledged the "possibility that some of the children might not be sent to the church schools if the parents were compelled to pay their children's bus fares out of their own pockets when transportation to a public school would have been paid for by the State."11 Even the Everson dissenters seemed to agree that the furnishing of police and fire protection and of water and sewage services to churches and church schools conformed with the establishment clause. ${ }^{12}$ Yet it may plausibly be said that all of these "in fact give aid and encouragement to religious instruction." ${ }^{13}$ Neither the fact of a "continumg and increasing demand for the state to assume" their cost, ${ }^{14}$ nor the fact that their provision by state funds affords the church "greater strength in our society than it would have by relying on its members alone"15 demonstrates their unconstitutionality. Some additional ingredient-some brighter line of demarcation-is necessary for invalidation of the expenditure of tax funds..$^{16}$

Thus, despite the Court's rather insistent declarations, "[p]redictability is still elusive." $"$ It is not clear that "a non-preferential expenditure of public moneys to religious institutions in furtherance of purposes in which government and the churches have concurrent interests may ... so deeply involve government in religious matters as to violate what the Court conceives to be the basic values served by the First Amendment."18 In sum, it does not appear that the Court has firmly foreclosed the issue of the constitutionality of aid to parochial education. ${ }^{10}$

\section{B. The Relevance of "History" and "Experience"}

Despite the fact that the Court has not absolutely precluded inquiry into the constitutionality of aid to parochial schools, it could be argued

\footnotetext{
11330 U.S. at 17.

12 See id. at 60-61 (dissenting opinion of Rutledge, J.).

13 Id. at 45 .

14 Id. at 46.

15 School Dist. v. Schempp, 374 U.S. 203, 229 (1963) (concurring opinion of Douglas, J.).

${ }^{16}$ See Lardner, How Far Does the Constitution Separate Church and State?, 45 Axs. Por. Scr. Rev. 110, 129 (1951).

17 Kempner, The Supreme Court and the Establishment and Free Exercise of Religion, in Religion and the Free Society, July 1958, at 65, 91 (pamphlet issued by The Fund for the Republic, New York, N.Y.).

18 Kauper, Schempp and Sherbert: Studies in Neutrality and Accommodation, in 1963 Recraron \& PUB. ORDER 3, 28-29 (D. Giannella ed.).

10 For further discussion, see text accompanying notes 285-318 infra. Professor Kurland has observed that "[a]nyone suggesting that the answer [to whether government may contribute financially to parochial education, directly or indirectly], as a matter of constitutional law, is clear one way or the other is either deluding or delucled." Kurland, Of Church and Stale and the Supreme Court, 29 U. C\#I. L. REv. 1, 96 (1961).
} 
that the history of the religion clauses of the first amendment has already determined the outcome. It has been contended that "history and experience may be sounder guides to locating Jefferson's 'wall of separation between church and state' than abstract logic."20 But reliance on history alone is futile. Perhaps it is true that "[n] o provision of the Constitution is more closely tied to or given content by its generating history than the religious clause of the First Amendment. It is at once the refined product and the terse summation of that history."21 But a recent, detailed inquiry into the practices, preferences, fears, and experiences of the entire generation that promulgated the religion clauses catalogues a wide assortment of possible explanations for their pliraseology and concludes that "it is impossible to give a dogmatic interpretation of the First Amendment, and to state with any accuracy the intention of the men who framed it . ....222

The historical facts are that free public education was virtually nonexistent during the early years of independence, ${ }^{23}$ and where it did occur it had a distinctly religious orientation. ${ }^{24}$ The relevance of the latter fact for the meaning of the establishment clause, however, is unconvincing in light of the further fact that established religions and clurches flourished in the colomies, ${ }^{25}$ persisting at times into the nineteenth century. ${ }^{26}$ And, if experience is to be our guide, it is perplexing to find that, despite provisions in almost all state constitutions which arguably, and often explicitly, prohibit public aid to sectarian schools, ${ }^{27}$ it was calculated twenty years

20 U.S. Dep't of Health, Education \& Welfare, Memorandum on the Impact of the First Amendment to the Constitution upon Federal Aid to Education, 50 Geo. L.J. 349, 357 (1961). See also Herberg, Religion, Demrocracy, and Public Education, in ReLIGIoN IN AMrerica 118, 142 (J. Cogley ed. 1958).

21 Everson v. Board of Educ., 330 J.S. 1, 33 (1947) (dissenting opinion of Rutledge, J.).

22 C. Antieat, A. Downey \& E. Roberts, Freedom Frome Federai Establishmient 142 (1964). See generally id. at 123-42. Also, compare C. Mozeriman, The Walt of Separation between ChuRcr and State (1951), and Pfeffer, Church and State: Something Less than Separation, 19 U. Car. L. Rev. 1 (1951), with J. O'NemI, ReLigion and EddCaTION UNDER tee Constitution (1949), and W. Parsons, The First Freedom (1948).

${ }^{23}$ See School Dist. v. Schempp, 374 U.S. 203, 238 \& n.7 (1963) (concurring opinion of Brennan, J.). See also Brown v. Board of Educ., 347 D.S. 483, 489-90 (1954).

24 C. ANTIEAT, A. DOWNEx \& E. ROBERTS, supra note 22, at 71.

${ }^{25}$ See Engel v. Vitale, 370 U.S. 421,428 \& n.10 (1962).

26 L. PesefFer, Church, State and Freedonc 141 (rev. ed. 1967).

27 A. Stokres \& L. PFefFer, Church and State in the UNTted States 423-24 (rev. ed. 1964); F. BeAce \& R. WIII, The State ANd Nonpubitc Schoors 15-19 (HEW, Office of Education Misc. No. 28, 1958). See also Note, Catholic Schools and Public Money, 50 Yare L.J. 917 (1941).

It may be urged that the existence of explicit constitutional prohibitions against aid to parochial schools in over $80 \%$ of the states, see A. STOKES \& L. PFEFFER, supra, presents compelling evidence as to the construction, in view of widespread tradition, that should be given to the establishment clause in respect to this issue. But there are several reasons wly the point is not persuasive. First, the language of the establishment clause is far from being as specifcally opposed to such aid as are many of the state mandates. See, e.g., MirN. Const. art. 8, 
ago that both federal and state funds "are actually being allocated, in no less than 350 instances, to American parochial schools today."28 And it is reasonable to assume that increased public concern with education has caused that number to grow significantly.

Most assuredly, however, history occupies a prominent role in the formulation of estabhshment clause principles. It has been properly utilized by the Court, not to discover the precise intention of the framers as to the controversial religious questions of today, ${ }^{20}$ but rather to "divulge a broad philosophy of church-state relations." ${ }^{130}$ History should furnish the informed perspective needed to fashion a rational constitutional standard that serves several purposes, including cognizance of the evil consequences feared by the framers, ${ }^{31}$ appreciation of values presently cherished, and capability of consistent application to the relevant problems. ${ }^{82}$ Too strong a reliance on history and experience, given their detailed inconsistencies which cannot be rationalized on principled grounds, will result only in ad hoc, unreasoned rulings. Such rulings conceal value judgments that, althougl inevitable in constitutional decisionmaking, should be laid bare by the articulation of general principles.

\section{The Purpose of the Article}

It lias been seen, at the threshold, that both Supreme Court rulings and first amendment history leave open the constitutional question of aid

\$ 2: "But in no case shall ... any public moneys or property, be appropriated or used for the support of schools wherein the distinctive doctrines, creeds or tenets of any particular Christian or other religious sect are promulgated or taught." This is evidenced by the fact that despite the Court's interpretation of the establishment clause in 1947 in Everson v. Board of Educ., 330 U.S. 1, permitting public payment of bus transportation of children to parochial schools, a number of state courts have subsequently held the practice invalid under their state constitutions. See, e.g., Matthews v. Quinton, 362 P.2d 932 (Alas. 1961), appeal dismissed and cert. denied, 368 U.S. 517 (1962); State ex rel. Reynolds v. Nusbaum, 17 Wis. 2d 148, 115 N.W.2d 761 (1962). Further, whereas the historical background of the establishment clause is virtually devoid of problems of education, see text at notes 23-24 supra, many of the state constitutional limitations were a direct response to Catlolic efforts to obtain public funds for parochial education. Note, Catholic Schools and Public Money, 50 Yare L.J. 917, 919-20 (1941). Thus, both the wording and setting of many of the state prohibitions, in contrast to the first amendment, clearly preclude any argument that certain aid to parochial schools is valid because it is nonreligious and serves a public purpose. Reed, The "Permeation" Issue in Federal Aid to Education, 8 CATHOLIC LAw. 197, 203-04 (1962). See also note 33 infra.

28 A. Johnson \& F. Yost, Separation of Church and State in the United States 112 (1948).

${ }^{29}$ See School Dist. v. Schempp, 374 U.S. 203, 241 (1963) (concurring opinion of Brennan, J.).

80 C. ANTIEAT, A. Downex \& E. RoBerts, supra note 22, at xi; see, e.g., Engel v. Vitale, 370 U.S. 421 (1962); McGowan v. Maryland, 366 U.S. 420 (1961); Everson v. Board of Educ., 330 U.S. 1 (1947).

${ }^{31}$ School Dist. v. Schempp, 374 U.S. 203, 236 (1963) (concurring opinion of Brennan, J.).

32 The specific role which each of these sometimes conflicting elements should play in constitutional adjudication is indeed a topic of substantial independent inquiry. 
to parochial schools. This article will propose a rule under the establishment clause ${ }^{33}$ for testing the constitutionality of aid to those parochial schools that provide at least some secular education. It is particularly appropriate, in dealing with this topic of aid to parochial schools, to recall Mr. Justice Frankfurter's warning that "preoccupation by our people with the constitutionality, instead of with the wisdom, of legislation or executive action is preoccupation with a false value." ${ }^{\prime 34}$ But it is constitutionality alone that must concern us here, irrespective of any preference as to the desirability of assisting nonpublic schools..$^{35}$ Perhaps in resolving this issue "the members of the Court must have recourse to their own convictions about the place of religion in education and public life, ${ }^{396}$ but surely not to the exclusion of other, more consequential determinants.

In brief, my proposal is that governmental financial aid may be extended directly or indirectly to support parochial schools without violation

${ }^{33}$ As has already been observed, see note 27 supra, the question under the various state constitutions may be wholly different. Because of the specificity of many of them, decisions thereunder may require a drawing of lines that will not withstand the test of being capable of "consistent apphication," see text accompanying note 32 supra, to a broad range of rationally similar prohlems. See the comment of Professor Jaffe in Dorsen, The Arthur Garfield Hays Civil Liberties Conference: Public Aid to Parochial Schools and Standing to Bring Suit, 12 Buffaio L. Rev. 35, 41 (1962).

The question under the establishment clause arises when a state aid program survives the state constitutional test, see, e.g., Board of Educ. v. Allen, 20 N.Y.2d 109, 228 N.E.2d 791, 281 N.Y.S.2d 799 (1967), prob. jutris. noted, 36 U.S.L.W. 3278 (U.S. Jan. 15, 1968), or in connection with the myriad of federal programs under which institutions with religious affliation receive federal funds through grants or loans. For a fairly complete listing of such programs, see Hearings Before the Ad Hoc Subcomm. on Study of Shared-Time Education of the House Comm. on Education and Labor, 88th Cong., 2d Sess. 32-48 (1964). See also text accompanying notes 559-69 infra. Especially important in this latter group is the Elementary and Secondary Education Act of 1965, 20 U.S.C. \$§ 236-44, 331-32b, 821-27, 841-48, 861-70, 881-85 (Supp. I, 1965), under challenge in six cases pending at the end of 1967. See American Jewish Congress, supra note 6.

34 Quoted in The Supreme Court on Church and State vii (J. Tussman ed. 1962).

35 See Kauper, Church and State: Cooperative Separatism, 60 Micr. L. Rev. 1, 39-40 (1961). A mass of literature and debate exists on the question of wisdom and legislative policy. An excellent brief summary may be found in L. Pferfer, Churci, State, ANd Freedom 521-29 (rev. ed. 1967). See genzerally, FEderat ATd and CathouIc Schoors (D. Callahan ed. 1964). Personally, I have no firm nor even well-informed judgment on the matter, although, as a believer in the virtues of a strong public educational system, I am troubled by the argument that the distribution of tax funds to private and parochial schools would result in their proliferation to the detriment of the public schools. See, e.g., Hearings on H.R. 2361 and H.R. 2362 Before the General Subcomm. on Education of the House Comm. on Education and Labor, 89th Cong., 1st Sess. 1533 (1965) (Statement on Behalf of the American Jewish Congress).

${ }^{36}$ Drinan, State and Federal Aid to Parachial Schools, 7 J. CHTRCH \& ST. 67, 71 (1965). Cf. Jones, The Constitutional Status of Public Funds for Church-Related Schools, 6 J. CHURCH \& Sr. 61, 70 (1964): "In the interpretation of the 'no establishment' clause, as in the interpretation of any other provision of the Constitution, it is impossible to achieve a surgically pure separation of 'law' from 'policy:" 
of the establishment clause so long as such aid does not exceed the value of the secular educational service rendered by the school.

The general theorem is not advanced as being wholly novel. It has been suggested by other commentators ${ }^{37}$ and inplicitly relied upon by state courts facing the question under state constitutions. ${ }^{38}$ But a thorough examination of its implications in light of history, precedent, principle, and intricacies in application is called for.$^{39}$ No attempt will be made here to predict the Court's future course of action. Rather, the proposed rule seeks to take account of "past event and initial purpose"40 and, in this light, to elaborate, as dispassionately as possible, a constitutional rationale "suitable for the government of the future."

Part II of the article explores a general rationale for the broad scope of the establishment clause, with particular emphasis on its historical and contemporary goals, and with incidental reference to the fourteenth amendment and to doctrines of standing. Part III describes the functioning of this establishment clause rationale. Part IV discusses the specific

37 The clearest statements appear in Blum, Our Federal Constitution and Equal Jistice

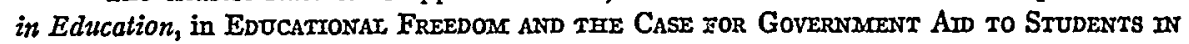
INDEPENDENT ScHoors 138-43 (D. MeGarry \& L. Ward eds. 1966); National Catholic Welfare Conference, The Constitutionality of the Inclusion of Church-Related Schools in Federal Aid to Education, 50 GEo. L.J. 397, 411, 434-35 (1961); Note, 36 Gro. L.J. 631, 645-46 (1948). See also Johnson, A Problem of Culture, in Religion and the Schools, April 1959, at 64, 70 (pamphlet issued by The Fund for the Republic, New York, N.Y.); Blum, Bis Rides for All Children, Scroor Acrivirses, Apr. 1967, at 6; Costanzo, Wholesome Nettrality: Law and Education, 43 N.D.I. REv. 605, 620 (1967); Rafalko, The Federal Aid to Private Schools Controversy: A Look, 3 DUQUESNE L. Rev. 211, 222 (1965); Slougls \& McAnany, Govcrnment Aid to Chutrch-Related Schools: An Analysis, 11 KaN. L. REv. 35, 69 (1962); NEW REPUBLTC, Mar. 2, 1963, at 4-5.

38 See St. Hedwig's Indus. School v. Cook County, 289 IIl. 432, 124 N.E. 629 (1919); Trost v. Ketteler Manual Training School, 282 II. 504, 118 N.E. 743 (1918); Dunn v. Addison Manual Training School, 281 Ill. 352, 117 N.E. 993 (1917); Dunn v. Chicago Indus. School, 280 IIl. 613, 117 N.E. 735 (1917); Murrow Indian Orphans Home v. Childers, 197 Okla. 249, 171 P.2d 600 (1946). See also Community Council v. Jordan, 432 P.2d 460 (Ariz. 1967). In several of these cases, the facts indicated that not only was public aid given to the religiously affiliated "schools" involved, but children of all religious faiths were committed to them by the juvenile court. Thus, although the matter was not raised, first amendment issues -free exercise and establishment-were there present that do not exist in the "ordmary" aid to parochial school case. See text at note 551 infra.

For state cases refusing to accept the proposed rationale, see Bennett v. City of La Grange, 153 Ga. 428, 112 S.E. 482 (1922); Synod v. State, 2 S.D. 366, 50 N.W. 632 (1891).

39 Without such an inquiry, one miglit agree with IMr. Justice Holmes that "no general proposition is worth a damn." 2 Holases-Pollock Letrers 59 (M. Howe 1st ed. 1961).

$40 \mathrm{M}$. Howe, The Garden AND THE WTIDERNESS 3 (1965).

41 Id. I do not believe that the discussion that follows derives in any significant part from my "own prepossessions about the wisdom of encouraging the maintenance of private schools with public funds." Drinan, supra note 36, at 71. Nor do I believe that "the underlying [constitutional] issue of the struggle is brutally simple: are parochial schools to be encouraged or not?" Note, Public Funds for Sectarian Schools, 60 HARv. L. Rev. 793, 800 (1947). See also note 35 supra. 
operation of the proposed rule for parochial schools. Part $V$ places the rule for aid to parochial schools in juxtaposition to competing theories, examining the efficacy of these other approaches and more fully illustrating the workings of the thesis advocated. Finally, Part VI briefly summarizes existing federal programs in aid of parochial education, measuring them against the rule proposed herein.

II

\section{AN ESTABLISHMENT CLAUSE RATIONALE}

A proposal permitting governmental financial assistance to parochial schools not exceeding the value of secular services they render comports with a general rationale for the establishment clause that reflects both contemporary and historical aims.

\section{A. Historical Support}

Althougl the indistinctness of the precise historical designs of the establisliment clause has already been noted, several aims emerge quite lucidly. Its paramount purpose then, like its major concern today, was to safegnard freedom of worship and conscience-in a word, to protect religious liberty. ${ }^{42}$ And it is equally clear that this purpose comprehended the intention that "the conscience of individuals should not be coerced by forcing them to pay taxes in support of a religious establishment or religious activities. ${ }^{243}$ In other words, as part of the general attempt to safeguard religious belief, the establishment clause sought to protect taxpayers from being forced by the federal government to support religion. This is cogently confirmed by Thomas Jefferson's "Virginia Bill for Religious Liberty" which proclaimed "that to compel a man to furnish contributions of money for the propagation of opinions which he disbelieves, is sinful and tyrannical"; 44 by James Madison's "Memorial and Remonstrance Against Religious Assessments" (whose title is itself revealing) which condemned even forcing "a citizen to contribute three pence only of his property" to support any religious establishment; ${ }^{45}$ by Thomas Cooley's Constitutional

42 See P. KaUPER, supra note 5, at 77; ReITGION AND AMarican Socrety 41 (Center for the Study of Democratic Institutions 1961); Dunsford, The Establishment Syndrome and Religious Liberty, 2 DUQuesne L. REv. 139, 203-12 (1964); Sky, The Establishment Clause, The Congress and the Schools: An Historical Perspective, 52 VA. L. Rev. 1395, 1426-27 (1966). For further discussion and citation of authority, see Choper, supre note 4 , at 333 nn.19-20.

43 Kauper, supra note 35, at 9. See also id. at 5-6. "The most serious infringement upon religious liberty before our Bill of Rights was adopted was the use of tax-raised funds for religious purposes." Pfeffer, Some Current Issues in Church and State, 13 W. Res. L. Rev. 9, 18 (1961).

4412 Hening, Statutes of Virganta 84 (1823). But cf. M. Howe, supra note 40, at 26. 45 I] 3, set forth in Everson v. Board of Educ., 330 U.S. 1, 65-66 (1947) (app.). See also 
Limitations which found clearly unlawful "under any of the American constitutions ... [c]ompulsory support, by taxation or otherwise, of religious instruction"; ${ }^{46}$ and by many important Supreme Court opinions in the church-state field-majority, concurring, and dissenting. ${ }^{47}$ Whatever other historical bases for the establishment ban, ${ }^{48}$ it is beyond reasonable dispute that it purported to secure rehgious liberty, in particular by prohibiting taxation for religious purposes. ${ }^{40}$ That historical intent conforms with the contemporary American view that "it is a violation of religious liberty to compel people to pay taxes to support religious activties or institutions."

\section{B. The Scope of the Establishment Clause}

Given this background, the broad philosophy of churcli-state relations reflected in the nonestablishment precept becomes manifest: Governmental action for religious purposes is highly suspect; ${ }^{61}$ it is constitutionally objectionable when it impinges on religious liberty either, as I have

Pfeffer, Federal Funds for Parochial Schools? No, 37 Notre DaMe Law. 309, 310-11 (1962); Flast v. Gardner, 271 F. Supp. 1, 6-7 (S.D.N.Y. 1967) (dissenting opinion of Frankel, J.): "It is now familiar to all who have touched this subject that a central concern-perhaps the most central concern-of the Establishment Clause is to ban utterly the use of public moneys to support any religion or all religions. ...

.....

....

"'Support' by use of taxpayers' money lay at the heart of Jefferson's and Madison's concern."

46 T. Cooley, A Treatise on tee Constitutional Lmatations 663-64 (7th ed. 1903).

47 See, e.g., Engel v. Vitale, 370 U.S. 421,442 n.7 (1962) (concurring opinion of Douglas, J.) ; McGowan v. Maryland, 366 U.S. 420, 453 (1961) (opinion of the Court by Warren, C. J.) ; McCollum v. Board of Educ., 333 U.S. 203, 248, 249 (1948) (dissenting opinion of Reed, J.); Everson v. Board of Educ., 330 U.S. 1, 8, 10-12 (1947) (opinion of the Court by Black, J.); id. at 33, 41, 44, 52, 53 (dissenting opinion of Rutledge, J.).

48 The contention has been advanced that the clause's purpose was to prevent Congress from interfering with the then existing state establishments. See, e.g., W. KaTz, RELIoION AND Amerrcan Constitutions 8-10 (1964); Snee, Religious Disestablishment and the Fourteenth Amendment, 1954 WASH. U.L.Q. 371; Note, 61 Nw. U.I. REv. 760, 769-70 (1966). The late Professor Howe found this argunent "[g]rammatically persuasive . . . [but] historically unconvincing," and suggested that the language drafted supported "a related, but less radical, interpretation of the prevailing policy" concerning the power of federal courts "to respect state law when it happened to sustain a religious enterprise." M. HowE, supra note 40, at 23.

49 See generally, C. ANTIEAU, A. DOWNEY \& E. RoBERIs, silpra note 22, at 1-29.

50 P. KaUper, supra note 5, at 14. See also, R. Dranan, Religion, The Courts, and PUBLIC POLICY 231 (1963).

51 The contention is not made that every governmental action that unay be fairly characterized as being exclusively for religious ends violates the establishment clause. If neither of the additional elements discussed in text accompanying notes 52-53 infra is present, it may persuasively be argued that, even though the governmental purpose is religious, it does not threaten the evils at which the establishment clause (or the free exercise clause) was directed, at least not in any ineaningful sense. See also notes 53, 55 infra; Mansfield, Book Review, 52 CaIIF. L. REv. 212, 219 (1964). 
argued elsewhere,$^{52}$ by compromising the individual's religious beliefs, or, as outlined above, by directly coercing the individual to support religion by allocating tax funds for sectarian use..$^{53}$ On the other hand, governmental action for secular purposes does not fall within the core of the establishment clause's concern ${ }^{54}$ - the "nonestablishment guarantee is directed at public aid to the religious activities of religious groups." ${ }^{255}$

\section{Conflicting Approaches}

(a) Absolutism.-This circumscription of the establishment clause has not met with universal approval. Some would have the clause invalidate

52 Choper, supra note 4.

53 This should be subject to a de minimis test. See id, at 351-53.

54 If comphance with such governmental action involves compromise of religious or conscientious beliefs, a free exercise violation may result. See, e.g., Sherbert v. Verner, 374 U.S. 398 (1963); In re Jenison, 265 Minn. 96, 120 N.W.2d 515, vacated and remanded, 375 U.S. 14, rev'd, 267 Minn. 136, 125 N.W.2d 588 (1963).

Whether such governmental action may still violate the establishment clause because alternative means to obtain its secular end are available that less directly affect religion is discussed in text accompanying notes 325-345 infra.

v5 P. Freund, Reitgion and the Public Schools 11 (1965) (emphasis added). See also Sky, supra note 42, at 1433: "[T]here is double historical support for the proposition that a law providing tax funds to religious organizations for the specific purpose of supporting religions functions is a law respecting an establislıment of religion." (Emphasis added.)

The basic establishment clause rationale just outlined is meant generally to deal with problems traditionally considered as arising under the nonestablisliment ban-matters such as direct or indirect public financial assistance to religious groups or institutions, religious activities sponsored by government, religious pronouncements by public officials, coercive state action coinciding with religious precepts-rather than with issues of alleged infringement of individual religious liberty, conventionally adjudicated under the free exercise clause. No comprebensive or final articulation of the establishment clause's every application is intended. That task may not be undertaken without thorough consideration of the fundamental question of the interrelationship between the establishment and free exercise clauses and the seeming "dilemmas" not infrequently posed thereby. See generally W. LOCKHART, Y. KaxISAR \& J. Choper, Constitutionat Law 1183-85 (2d ed. 1967).

In resolving a conflict between practices demanded by one's religion and civil regulation, the Court has acknowledged that "to make accommodation between the religious action and an exercise of state authority is a particularly delicate task." Braunfeld v. Brown, 366 U.S. 599,605 (1961). Decision in favor of the former requires the state to serve the religious interest of the individual. Such state action to prevent a free exercise clause violation inay be "defined" as being for a "nonreligious" purpose. See Choper, supra note 4, at 393, 402 . See also Moore, The Supreme Court and the Relationship Between the "Establishment" and "Free Exercise" Clanses, 42 Tkxas I. Rev. 142, 196-97 (1963). In other instances, a state may be permitted, although not required, to facilitate personal liberty by relieving a serious burden placed on religious exercise by government action. See Mansfield, Conscientions $O b$ jection-1964 Term, 1965 ReIIGION \& PUB. ORder 3, 70-71 (D. Giannella ed.). See generally Katz, Freedom of Religion and State Neutrality, 20 U. CEr. L. Rev. 426 (1953). Such a course may be characterized as being for a "restorative or equalizing" purpose. See Galanter, Religious Freedoms in the United States: A Turning Point? 1966 Wrs. L. Rev. 217, 290-91. These matters may well call for some qualification of the fiteral reach of the establishment clause rationale set forth above. But of. note 199 infra (last three paragraphs). 
any governmental support to certain institutions controlled by a church or religious organization "[e]ven if a completely secular part of [the institution's services] could be isolated." The This seemingly "absolutist" theory will be discussed below. ${ }^{87}$

(b) Neutralism.-Another highly respectable thesis falls on the opposite side of the spectrum. Under the doctrine developed by Professor Kurland, which states simply "that government cannot utilize religion as a standard for action or inaction," it would seem that government could constitutionally finance the entire operational costs of all state-accredited educational institutions, including those controlled by a religious organization, because the classification-state-accredited educational institutionswhich includes most ordinary parochial schools, is not in the religious terms which his doctrine forbids. ${ }^{\text {s9 }}$

\footnotetext{
58 G. LaNoug, Pubitc Funds for Parochtac Schools? 32 (1963).

57 See text accompanying notes 346-353 infra.

58 Kurland, supra note 19, at 6. See also Hutchins, The Future of the Wall, in Tre WaIt BETWEen ChurCh aND STate 17, 22 (D. Oaks ed. 1963).

59 Professor Kurland's doctrine also addresses itself to a proper construction of the frec excrcise clause, urging that it be considered abridged by a government "classification in terms of religion ... to impose a burden." Kurland, supra note 19, at 6. Under this test, he would find a free exercise violation if government extended financial support to all stateaccredited schools except those that are church-related. Id. at 15 n.57, 70. See also Kauper, Separation of Church and State-A Constitutional View, 9 CATHoxic Law. 32, 42 (1963). But he would find no violation if the government classification were "in terms of public and non-public schools." Kurland, supra note 19, at 15 n.57.

A discussion of the implications of the free exercise clause on the aid to parochial school question is generally beyond the scope of this article. It has been stated that the free exercise rights of parents wishing to have their children educated in parochial schools are infringed if aid equivalent to that given to public schools is not also extended to parochial schools. However, it has been vociferously maintained that the suggestion is "wholly unjustified," Letter from Professor Howe to Senator Wayne Morse, in S. Doc. No. 29, 87th Cong., 1st Sess., at 50 (1961), and that the free exercisc contention "elevate[s] an argument bascd on concepts of equity to the dignity of a contention grounded in the Constitution." Id. See also U.S. Dep't of Health, Education \& Welfare, supra note 20, at 374-75; Pfeffer, sulpra note 43, at 14-18. But the contention is by no means "clearly without foundation," W. KATz, supra note 48 , at 75 .

Although the argument has been extant for some time, see V. BLUM, FrEEDOM or Chotce in Education 38-61, 106-32 (1958); W. Parsons, The First FreEdons 122 (1948); Henle, American Principles and Religious Schools, 3 St. Lovss U.L.J. 237 (1955); Weclew, Church and State: How Much Separation?, 10 DE PAUL L. REv. 1, 19 (1960); 1 BUIL of RTGETS REv. 309 (1941), it has gained significant force froin the Supreme Court's decision in Sherbert v. Verner, 374 U.S. 398 (1963). Sherbert involved a state's denial of unemployment compensation benefits to a Seventh Day Adventist who would not work on Saturday, the Sabbath Day of her faith; the state commissioner thus found that she had failed "without good cause, to accept 'suitable work' ...." Id. at 401. The Court, in holding that her rights under the free exercise clause were violated, made several salient points relevant to the aid to parochial schools issue: First, it ponited out that Mrs. Sherbert's "ineligibility for benefits derives solely from the practice of her religion." Id. at 404. Similarly, a Catholic child attending a parochial school is ineligible for the financial benefits granted other stateaccredited schools (i.e., public schools) solely because of the dictates of his religion; that
} 
A shortcoming of this approach is that it permits the employment of tax-raised funds for strictly rehgious purposes. Seemingly, this doctrine would allow the use of public money for the construction of churches and synagogues if the legislative classification were broad enough-say, a statute allocating funds for new structures to house all voluntary associations, enacted on the ground that members lacked requisite resources for

Catholic parents liave "the duty of entrusting their children to Catholic schools wherever and whenever it is possible," Pope Paul VI, Decree on Christian Education (1965), reprinted

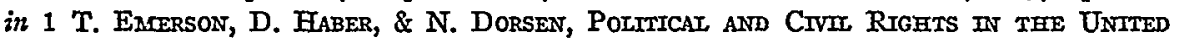
States 1079, 1081 (3d ed. 1967), hardly requires citation. See also the Canon Laws of the Roman Catholic Church, reproduced in Everson v. Board of Educ., 330 U.S. 1, 22-23 (1947) (dissenting opinion of Jackson, J.). But cf. R. DrñaN, supra note 50, at 190-92. Second, the Court noted that "the pressure upon [Mrs. Sherbert] to forego [her religious] practice is unmistakable," 374 U.S. at 404. Given the well-publicized financial predicament of parochial schools and the importance of effective education to children, a similar pressure exists to attend a better financed public school. Third, as in Sherbert, denying financial aid to parochial schools "forces [the Catholic child] to choose between following the precepts of [his] religion and forfeiting benefits, on the one hand, and abandoning one of the precepts of [his] religion ... on the other hand." Id. Finally, the Sherbert Court concludes that "to condition the availability of benefits upon this appellant's willingness to violate a cardinal principle of her religious faith effectively penalizes the free exercise of her constitutional liberties." Id. at 406. It is not difficult to reach a similar conclusion in respect to denying public aid to Catholic parochial schools. See generally School Dist. v. Schempp, 374 U.S. 203, 312-13 (1963) (dissenting opinion of Stewart, J.); Blum, Out Federal Constitution and Equal Justice in Education, in Eddcattonar, Freedoms and tere Case for Governasent Am to Students In Independent Schoors 154-57 (D. McGarry \& L. Ward eds. 1966) [hereinafter cited as Eddcattonat. FreEDon]; Blum, Freedom and Equality, in FeDERAT Am AND Catronic Schoors 43, 51-54 (D. Callahan ed. 1964); Drinan, Does State Aid to ChurchRelated Colleges Constitute an Establishment of Religion?-Reflections on the Maryland College Cases, 1967 Uтав L. Rev. 491, 511-15; Farhat, The Michigan School Bus Law, Micr. State B.J., Apr. 1964, at 28, 31; Regan, Religious Neutrality, 110 Amserrca 74 (1964); Rice, The New York State Constitution and Aid to Chutch-Related Schools, 12 CatrocIc LAw. 272, 321 (1966); 19 S.C.L. REv. 242 (1967).

It may even be argued that the free exercise claim for aid to parochial schools is yet more compelling than Mrs. Sherbert's successful claim. When the state sends Mrs. Sherbert ler unemployment compensation check, as the Court ordered that it do, thus excusing lier from taking "suitable work" because of her conscientious scruples, the state's action is taken solely to facilitate religious exercise-the state's purpose may be said to be religious. See note 55 supra. In the view of some analysts, such action raises serious establishment clause problems. See Kurland, supra note 19, at 94; cf. Sherbert v. Verner, supra, at 415 (concurring opinion of Stewart, J.). But when the state finances the nonreligious aspects of education in parochial schools, its purpose, as will be demonstrated infra, see text at notes $145-149$, is secular, thus removing this possible objection. See W. LockFarT, Y. KaATSAR \& J. Choper, Constitutronat, Law 1185-86 (2d ed. 1967).

It is not meant by this brief discursiveness to speculate as to the Court's resolution of the free exercise claim if it were advanced. In fact, the Court's denial of certiorari in Swart v. South Burlington Town School Dist., 122 Vt. 177, 167 A.2d 514, cert. denied, 366 U.S. 925 (1961), in which the state court rejected the contention, does not bode well for its ultimate success. See also Dickman v. School Dist., 223 Ore. 347, 366 P.2d 533 (1961), cert. denied, 371 U.S. 823 (1962). Nor is it meant to suggest that the persuasiveness of the free exercise argument follows conclusively from Sherbert. Perhaps a "compelling state interest," 374 U.S. at 406, found necessary but wanting in Sherbert, to justify the "sub- 
such undertaking. ${ }^{60}$ Although such a statute may not be said to give intentional and purposeful support to religion, in the sense that it "singles out a religion, or rehgions generally, for direct financial assistance," particular statute's clear effect contradicts a vital value underlying the establishment clause. ${ }^{63}$ The breadth of the classification-using tax funds to support buildings for the Rotary, Odd Fellows, and Chamber of Commerce, in addition to recognized (and nonconformist) religions-would seem to many people only to add pocketbook insult to constitutional injury. ${ }^{64}$ Even the most avid proponents of aid to parochial schools would seem to agree that such subsidies of religion are not permissible. ${ }^{05}$ Whether consciously or not, the "official support of the State or Federal Govern-

stantial infringement," $i d$., of the free exercise right will be shown in the aid to parochial schools context-perliaps the essentiality of conserving the public fisc, perhaps the notion (with which I disagree) that to grant the aid would itself violate the letter or spirit of the establisliment clause. The point is that the free exercise allegation is surely not "sheer sophistry," 78 CHRISTIAN CENTURY 508 (1961) (editorial).

Father Drinan has made the following contention for the constitutional compulsion of aid to parochial schools: because "of clear Supreme Court rulings prccluding sectarian teaching and religious practices in public schools it can be persuasively argued that the granting of funds only to the public school is a violation of the establishment clause because such a policy endorses and prefers one educational and philosophical orthodoxy [a "religion . . of secularism," R. DRnNaN, supra note 50, at 193] over all others." Drinan, The Constitutionality of Public Aid to Parochial Schools, in THE WALL BETWEEN CHURCH AND STATE 55, 72 (D. Oaks ed. 1963). Even if the "religion of secularism" assumption were to be valid, but see note 224 infra, the contention as a plca for financial aid must fail. It ignores the Court's unequivocal pronouncement that the establishment clause forbids governmental support of all religions, not merely preference of one religion over another. School Dist. v. Schempp, 374 U.S. 203, 216 (1963). See also S. Hook, Reuigron IN A FreE SoctetY 16 (1967).

60 See LaNoue, The Child Benefit Theory Revisited: Textbooks, Transportation and Medical Care, 13 J. PUв. L. 76, 89 (1964).

With respect to the free exercise clause, the Kurland thesis las been recently rejected by the Court in Sherbert v. Verner, 374 U.S. 398 (1963). With respect to the establishment clause, the Court, consistent with the Kurland thesis, has to date invalidated only governmental action strictly directed to religious ends. McCollum v. Board of Educ., 333 U.S. 203 (1948); Torcaso v. Watkins, 367 U.S. 488 (1961); Engel v. Vitale, 370 U.S. 421 (1962); School Dist. v. Schempp, 374 U.S. 203 (1963). But it is fair to note that the thesis has never really been put to the test in the establishment cases, as in a situation just hypothesized in the text.

61 Cf. McCollum v. Board of Educ., 333 U.S. 203, 248 (1948) (dissenting opimion of Reed, J.).

62 Dunsford, supra note 42 , at 205.

63 See text accompanying notes 43-50 supra. See also U.S. Dep't of Health, Education \& Welfare, supra note 20 , at 373 .

64 But cf. 77 HaRv. L. Rev. 1353, 1357-58 (1964).

65 See Hearings on H.R. 2361, supra note 35, at 821 (Statement of Msgr. McManus). See also R. DRINAN, supra note 50, at 231; statement of Msgr. Gallagher, quoted in id. at 29. The fact that a public subsidy of religion may attract more people to it, thus resulting in a net increase in the operating costs of the church, see Matthews v. Quinton, 362 P.2d 932, 953 (Alas. 1961) (dissenting opinion), is, of course, irrelevant: to the analysis. 
ment would be placed behind the tenets of one or of all orthodoxies. This the Establishment Clause prohibits." $" 66$

(c) Divisiveness.-It has frequently been declared that the function of the establishment clause is "above all, to keep bitter religious controversy out of public life by denying to every denomination any advantage from getting control of public policy or the public purse." ${ }^{27}$ The conflict among religions brought about by a struggle for public funds is surely unfortunate and undesirable. ${ }^{68}$ And upholding the constitutionality of some amounts of aid to parochial schools or to the children that attend them might well push in this direction." One might agree that "if government interferes in matters spiritual, it will be a divisive force,"70 thus making sucl action constitutionally suspect. But to make "divisiveness" determinative of constitutionality, despite the secular nature of the governmental program in controversy, is neither a desirable nor a workable approach to the problem. ${ }^{71}$

Whether rightly or wrongly, the various churches and religious groups have exerted powerful political influence in national and state legislative halls ${ }^{72}$ - frequently in disagreement with one another-concerning sucl causes as Sunday closing, ${ }^{73}$ gambling, prohibition, abolition, integration, overpopulation, birth control, sterilization, marriage, and divorce. Surely such legislation is not therefore invalid. Nor would a denial of aid to parochial schools largely diminish the extent of religious political activity. In fact, it "might lead to greater political ruptures caused by the alienation of segments of the religious community."T4 Those who send their children to parochial schools might intensify opposition to increased governmental aid to public education on the ground that it raises their taxes without direct personal benefit, decreases their financial ability to support the parochial schools, and augments the operational costs of parochial schools seeking to maintain qualitative parity with the improved public schools. ${ }^{\mathbf{7 5}}$

66 School Dist. v. Schempp, 374 U.S. 203, 222 (1963).

67 Everson v. Board of Educ., 330 U.S. 1, 27 (1947) (dissenting opinion of Jackson, J.). See also McCollum v. Board of Educ., 333 U.S. 203, 228 (1948) (concurring opinion of Frankfurter, J.).

${ }^{68}$ See Van Alstyne, Constitutional Separation of Church and State: The Quest for a Coherent Position, 57 Ax. Por. Scr. Rev. 865, 868 (1963).

60 See Everson v. Board of Educ., 330 U.S. 1, 53-55 (1947) (dissenting opinion of Rutledge, J.) ; A. JoHnson \& F. Yost, supra note 28 , at 113.

70 Engel v. Vitale, 370 U.S. 421, 443 (1962) (concurring opinion of Douglas, J.).

71 See Choper, supra note 4 , at 385-86.

72 See M. Hows, supra note 40, at 62 ; P. KAUPER, supra note 5, at 83-85; RexigIoN AND AXIERICAN SOCLETx, supra note 42, at 71; see text accompanying notes 100-01 infra.

73 See McGowan v. Maryland, 366 U.S. 420, 435 (1961).

7477 HaRV. L. REv. 1357 (1964).

75 Cf. Mitchell, Religion and Federal Aid to Education, 14 Law \& Contemp. ProB. 113, 122-27 (1949); Whelan, School Question: Stage Two, 105 Amerrca 17 (1961). 


\section{Application to the States}

Before proceeding further, certain other peripheral matters may be treated. The discussion to this point has assumed that the first amendment's mandate, that "Congress shall make no law respecting an establishment of religion," is equally apphicable, through the fourteenth amendment, to action by the states. This lias been the Court's consistent position and, in view of this, the Court lias recently noted that contrary arguments "seem entirely untenable and of value only as academic exercises."

Examination of the dispute, however, may help to clarify the scope of the establishment clause. The relevant fourteenth amendment language is that "no State shall ... deprive any person of life, liberty, or property, without due process of law...." It is therefore asserted that the fourteenth amendment should forbid only those violations of the first amendment's establishment clause that "significantly affect the secured liberties of individuals"77 so as to deprive them of such liberty without due process of law-the implication being that some establishment clause infractions do not significantly impair fourteenth amendment liberties. ${ }^{78}$ It is this suggestion that may be challenged.

The suggestion assumes that while the fourteenth amendment prevents infringements of liberty which "significantly affect" the individual, the first amendment forbids abridgements which do not do so. It bears repeating, however, that a central design of the establishment clause was that it act "as a co-guarantor, with the Free Exercise Clause, of rehigious liberty," ${ }^{\prime \prime 2}$ by preventing the government generally from coercing religious belief and specifically from compulsorily taxing individuals for strictly religious purposes..$^{80}$ If nonsecular federal action involves either of these consequences, I would suggest that it has "significantly" affected indi-

76 School Dist. v. Schempp, 374 U.S. 203, 217 (1963). See generally id. at 215-16.

77 Howe, The Constitutional Question, in Religion and the Free Society, supra note 17, at 49,61. See also P. KAUPER, supra note 5, at 56.

78 See M. Howe, supra note 40, at 138.

79 School Dist. v. Schempp, 374 U.S. 203, 256 (1963) (concurring opinion of Brennan, J.). See also id. at 227 (concurring opinion of Douglas, J.); id. at 312 (dissenting opinion of Stewart, J.); Lardner, How Far Does the Constitution Separate Church and State?, 45 Axr. Por. Scr. REv. 110, 128 (1951); note 42 supro.

Whatever the historical foundation for the notion that the clause was intended to bar Congress from disestablishing the state establishments, see note 48 supro, it is of little pragmatic relevance today because of the nonexistence, and patent invalidity under the fourteenth amendment, of any formal state establishment. Of course, as a matter of logic, this purported goal of the establishment clause could not be made applicable to the states through the fourteenth amendment. See W. KATZ, supra note 48, at 11 .

80 See text accompanying notes 43-50 supra. 
vidual freedom. ${ }^{81}$ Thus, if such state action involves either, ${ }^{82}$ it has seemingly violated the fourteenth amendment by "significantly" affecting personal liberty. ${ }^{83}$ However, if federal action involves neither consequence, then I would suggest that the establishment clause itself-as a matter of constitutional construction-has probably not been breached. The establisliment clause, in sum, may well ban no activity that should not also be held to violate the fourteenth amendment, consistent literally with the latter's relevant language. ${ }^{84}$

\section{Standing of Federal Taxpayers}

The question of a federal taxpayer's standing to challenge federal aid to parochial schools-or, for that matter, aid for church construction itself-is generally beyond the scope of the discussion. ${ }^{85}$ But again, brief inquiry may be enlighteming in examining the reach of the estabhishment bar.

Frothingham v. Mellon ${ }^{86}$ holds that a taxpayer's interest in federal appropriations is too minute, remote, uncertain, and indeterminable to support a suit challenging federal spending. Whether the decision rests on a finding that the inatter therefore does not meet the "case or controversy" requirement of article III of the Constitution, or whether it is

81 See note 51 supra. See School Dist. v. Schempp, 374 U.S. 203, 295 (1963) (concurring opinion of Brennan, J.) ; id. at 308 (concurring opinion of Goldberg, J.). See also Choper, supra note 4, at 331 n.8. Cf. text accompanying note 333 infra.

82 See text accompanying notes 51-53 supra.

83 Such use of tax funds might also be characterized as a deprivation of property without due process of law.

84 For an interesting and novel analysis that would make the religion clauses of the first amendment applicable to the states via the equal protection clause of the fourteenth amendment, see Kauper, The Constitutionality of Tax Exemptions for Religious Activities, in THE WaIt Between Church and State 95, 101-02 (D. Oaks ed. 1963).

85 The issue of whether the rule of Frothingham v. Mellon, 262 U.S. 447 (1923), bars a suit by a federal taxpayer challenging aid to parochial schools is specifically presented in a case now pending before the Supreme Court. Flast v. Gardiner, 271 F. Supp. 1 (S.D.N.Y.), prob. juris. noted, 389 U.S. 895 (1967). See also Elliott v. White, 23 F.2d 997 (D.C. Cir. 1928) (no standing); Protestants and Other Americans Umited v. O'Brien, 272 F. Supp. 712 (D.C. 1967) (no standing); Protestants and Other Americans United v. United States, 266 F. Supp. 473 (S.D. Ohio 1967) (no standing).

That local and state taxpayers have standing in the Supreme Court, if granted standing in the state court, to challenge local and state expenditures seems clear from the decided cases, Everson v. Board of Educ., 330 U.S. 1 (1947); Cochran v. Louisiana State Bd. of Educ., 281 U.S. 370 (1930), although the issue has rarely been discussed by the Court. See Doremus v. Board of Educ., 342 U.S. 429 (1952). The possibility that a taxpayer's suit to enjoin state expenditures allegedly in violation of the establishment clause might lie in the federal district courts despite the state's refusal to recognize such an action is discussed in Sutherland, Due Process and Disestablishment, 62 HARv. I. REv. 1306, 1330-35 (1949).

80262 U.S. 447 (1923). 
based only on a judicial rule of self-limitation, is unclear. ${ }^{87}$ But even if it is the former, a taxpayer's suit based on an alleged establishment clause violation is arguably distinguishable from Frothingham.

The ordinary federal taxpayer's suit urges simply that the congressional appropriation is ultra vires-beyond the national power and thus "reserved to the States" by the tenth amendment. The gravamen of the claim is that there has been a violation of states' rights (although the allegation is frequently added that this results in a deprivation to the individual of property without due process of $1 \mathrm{w}^{88}$ ). In such circumstances, the Court has good reason to decline jurisdiction ${ }^{80}$ - to find "essentially a matter of public and not of individual concern"; quire the taxpayer "to show ... that he has sustained or is immediately in danger of sustaining some direct injury ... and not merely that he suffers in some indefinite way in common with people generally." "11

When the federal taxpayer's suit urges that the congressional appropriation violates the establishment clause, however, his claim is not merely one of ultra vires. The expenditure of compulsorily raised tax funds for rehigious purposes, both historically and contemporarily, may well be characterized as an abridgment of individual religious liberty. ${ }^{02}$ The issue is not only one of states' rights; it may be one of alleged governmental infringement of individual rights protected by the Constitution. ${ }^{8 a}$ "Direct injury" has allegedly been "suffered"- -and not "in some indefinite way." Mr. Justice Jackson recognized that "[0]ne of our basic

87 This issue would be crucial were Congress to enact a statute authorizing taxpayers to attack federal expenditures on establishment grounds. Such legislation has, at different times, passed the House, H.R. 4643, 81st Cong., 1st Sess. \& 5 (1949), and the Senate, S. 2097, 89th Cong., 2d Sess. (1966), but never both houses together. If Frothingham were based on article $\mathrm{HI}$, such legislation would be unconstitutional. Compare Manning, Aid to EducationFederal Fashion, 29 ForDHAM L. REv. 495, 506 (1961); U.S. Dep't of Health, Education \& Welfare, supra note 20, at 381; Comment, 8 VIII. I. REv. 224, 230-31 (1962-63), with Professor Jaffe's view in Dorsen, supra note 33 , at $\mathbf{5 1}$. On this possibility, a number of legislative devices, other than a taxpayer's suit, have been developed as conceivable avenues for testing federal expenditures under the establishment clause. See Jaffe, supra, at 64-65; U.S. Dep't of Health, Education, \& Welfare, supra note 20 , at 382 ; 77 HnRv. L. Rev. 1357, 1360 (1964). See also True, Nov. 25, 1966, at 55-56. The Elementary and Secondary Education Act of 1965, 20 U.S.C. $\$ \S 241 \mathrm{k}, 827,869$ (Supp. I, 1965), presents this potential. See Drinan, Standing to Sue in Establishment Cases, 1965 Rusigron \& PuB. Order 161, 165 (D. Giannella ed.).

88 E.g., Frothingham v. Mellon, 262 U.S. 447, 482, 486 (1923). See generally Lewis, Constitutional Rights and the Misuse of "Standing," 14 STAN. L. REv. 433 (1962).

${ }^{89}$ See Choper, On the Warren Court and Judicial Review, 17 CathoLIC U.I. Rev. 20, $39-40$ (1967).

90 Frothingham v. Mellon, 262 U.S. 447, 487 (1923).

$91 \mathrm{Id}$. at 488 .

02 See text accompanying notes 43-50, 79-80 supra.

93 See Choper, supra note 89, at 39-41.

94 Frothingham v. Mellon, 262 U.S. 477, 488 (1923). 
rights is to be free of taxation to support a transgression"95 of the estabhishment clause; that the Court "had jurisdiction" "[w] here a complainant is deprived of property by being taxed . . . to support a religious estabhshment. ${ }^{390}$ Thus, Frothingham may be inapplicable to a suit based not on the tenth amendment, but rather on the establishment clause. ${ }^{97}$

The establishment clause rationale described herein concludes that the clause generally forbids nonsecular governmental action which infringes rehgious behefs and specifically bars coercive taxation for strictly rehgious purposes. Under this rationale, governmental spending for secular purposes is permissible. This rationale is not only consistent with contemporary and historical values underlying the establishment clause, but also affords an evaluative perspective for the problems of the role of the fourteenth amendment and the question of standing to sue.

\section{III \\ DEFINITION OF SECULAR PURPOSE}

The broad establishment clause rationale described above would generally forbid government expenditures for strictly religious purposes and would bar governmental action for these purposes if infringements of religious liberty followed. On the other hand, it would generally permit the state to act for secular purposes. Thus, it is analytically critical to decide what constitutes a secular purpose and how it should be determined. This is frequently a perplexing inquiry because a law may be enacted for a multiplicity of purposes and may produce a multiphicity of effects. ${ }^{98}$ A Sunday closing law, for example, may have the secular purpose of promoting the general welfare by creating a day of respite or the religious purpose of forbidding work to enhance churcli attend. ance. $^{99}$

Certain aspects of the problem are quite clear. The fact that rehigious groups sponsored a law-or even were its sole sponsors-does not make its purpose nonsecular; ${ }^{100}$ the Civil Rights Act of 1964 might not have passed without the support of churchmen. ${ }^{101}$ Nor, with the rare and

95 Everson v. Board of Educ., 330 U.S. 1, 22 (1947) (dissenting opinion).

$96 \mathrm{McC}$ lllum v. Board of Educ., 333 U.S. 203, 233-34 (1948) (concurring opinion).

97 An allegation that federal funds are being expended for religious purposes, sufficient to support standing, should not, of course, be misidentified with the question of whether the money is in fact being so used-which goes to the merits of the case. But see Drinan, supra note 87 , at 172 .

88 See Van Alstyne, supra note 68, at 875.

90 See McGowan v. Maryland, 366 U.S. 420 (1961).

100 See text following note 72 supra.

101 See Carroll, The Constitution, The Supreme Court, and Religion, 61 Arr. Pox. Scr. REv. 657, 662 (1967). 
limited qualification to be noted below, ${ }^{102}$ slould existence of a secular purpose turn on judicial examination of legislative motives ${ }^{103}$-a long, forbidden psychoanalytic attempt to find the "real reason," articulated or unspoken, for passing a law. ${ }^{104}$ Rather, wliether government action is secular or religious should generally be determined by the nature of its independent or primary effect (a term to be illustrated below, and not to be confused with "principle" or "paramount" effect). If the primary effect is to accoinplish a nonrehigious public purpose, the action slould generally be held immune from establishment clause attack. ${ }^{105}$ But if the primary effect is to serve a religious end, the action's purpose should not be characterized as secular even thougli an ultimate or derivative public benefit may be produced. ${ }^{108}$

\section{A. Illustrations}

Specific instances are necessary to illustrate the point. It has been maintained that pubhic school prayer recitation and Bible reading serve the secular purpose of producing profound convictions in children, thus making them better citizens. ${ }^{107}$ But if such are the cffects, they come about only if the primary goal of these practices-the implanting of spiritual and religious beliefs-is achieved; the purported secular ends are derivative from the primary rehigious effect. Thus, under the analysis suggested above, the purpose of the governmental action is religious.

Sunday closing laws also serve an undeniably religious end by encouraging church attendance in removing the obstacle of having to report for work. But they also produce an independent secular effect-"a Sunday atmosphere of recreation, cheerfulness, repose and enjoyment."108 And this secular effect is in no way dependent on or derived from the religious inpact of the statute.

Governmental actions whose secular benefits flow from the achievement of a primary religious effect must be suspect under the establishment clause. ${ }^{109}$ Such actions "employ Religion as an engine of Civil

\footnotetext{
102 See text accompanying note 114-24 infra.

103 Van Alstyne, supra note 68, at 876.

104 See McGowan v. Maryland, 366 U.S. 420, 466, 469 (1961) (concurring opinion of Frankfurter, J.) ; A. Bickar, The Least Dangerous Branch 208-21 (1962).

105 See text accompanying notes 325-45 infra.

${ }^{106}$ See Choper, supra note 4, at 334-38. See also Hammett, The Homogenized Wall, 53 A.B.A.J. 929, 933 (1967).

107 See discussion in Choper, supre note 4 , at 336.

108 McGowan v. Maryland, 366 U.S. 420, 448 (1961).

109 I have argued that such actions should be invalid if either of two additional factors are present. See text accompanying notes 51-53 supra. This distinction should satisfy the ohjection of Lardner, supra note 79, at 132, that "the puhlic welfare argument amounts to the automatic validity of all legislation" because "[a]ll legislation in a democracy arises
} 
policy."110 Allowing such actions would literally read the clause out of the first amendment; it would justify government subsidization of that church that the government found best inculcates its members with the deep convictions that make for better citizenship. ${ }^{111}$ But governmental action that produces independent secular efforts should generally be unassailable even if an equally necessary or inevitable effect is the benefitting of religion. If not, the fire department could not protect burning churches.

\section{B. Judicial Determinations}

This is not to say that the task of distinguishing primary religious and secular effects is always free of difficulty. But usually it is. Thus, in Torcaso v. Watkins, the Court observed that there could be "no dispute about the [religious] purpose or effect"112 of a requirement that public officeholders declare a belief in God. And in Engle v. Vitale, the Court had "no doubt that ... . daily classroom invocation of . . . the Regents' prayer is a religious activity."113

On occasion, governmental action with a primary religious effect may be wrapped "in the verbal cellophane"114 of a secular purpose. Thus, in the Bible Reading Cases the state argued secular purpose-" the promotion of moral values, the contradiction to the materialistic trends of our times, the perpetuation of our institutions and the teaching of hiterature."115 The Court easily rejected the assertion, agreeing instead with the trial court's finding that the exercises had a religious character. ${ }^{116}$

In such instances, the Court is not-nor should it be-making the

from the belief that it promotes the public welfare," and that of Carroll, supra note 101, at 662-63.

$110 \mathrm{~J}$. Madison, Memorial and Remonstrance Agatnst Rextgiods Assessmaents, If 5, set forth in Everson v. Board of Educ., 330 U.S. 1, 67 (1947) (app.).

111 See text at note 107 supra. See also McCloskey, Principles, Powers, and Vatues: The Establishment Clause and the Supreme Court, 1964 REXIGION \& PUB. ORDER 3, 26 (D Giannella ed.): "[A] religious law for a religious end .... offends one religious conscience in the name of another, and unless we reject the sovereignty of religious belief, we must find this blameworthy. Nor is such a law vindicated by the contention that it employs religious means to a secular end, i.e., the development of a moral citizenry which will in turn produce a just and happy society. For whatever tendency the means have to accomplish that end may be canceled by their simuitaneous tendency to generate the bitterness that makes such a society difficult." See also School Dist. v. Schempp, 374 U.S. 203, 278-81 (1963) (concurring opinion of Brennan, J.).

112367 U.S. 488,489 (1961).

113370 U.S. 421,424 (1962).

114 United States v. Kahriger, 345 U.S. 22, 38 (1953) (dissenting opinion of Frankfurter, J.).

115 School Dist. v. Schempp, 374 U.S. 203, 223 (1963).

110 Id. Similarly, I suggest that the Court would reject the contention that requiring the memorization of the Catechism in public schools serves the secular purpose of teaching the techmique of memory. But cf. Paul v. Dade County, 202 So. 2d 833 (Fla. Dist. Ct. App. 1967). 
judgment that any secular purpose of the law fails to be paramount over whatever religious end the church obtains by the regulated conduct. ${ }^{117}$ For the Court to engage in such an ad hoc balancing process ${ }^{118}$-relying only on the Justices' subjective notions of paramountcy-to treat the problem as "one of degree," standards are available. ${ }^{120}$ Even where a religious purpose exists, the state's secular purpose need not be dominant or paramount; ${ }^{121}$ the existence of a "legitimate" independent primary secular purpose should be sufficient. The determination of "legitimacy" by the Court undeniably involves the making of a not wholly objective judgment. But, unlike the "dominancy-paramountcy" inquiry, it is a judgment of a quite limited nature, mainly disposed of by common sense and observation of the obvious effects of the enactment. ${ }^{122}$ Although the inquiry is necessitated by a recognition that a disingenuous legislature can easily find secular purposes to cover any religious interest it wishes to further, ${ }^{123}$ such a cover is almost always revealed as cellophane. ${ }^{124}$

A few additional illustrations may be helpful. In 1921, the California legislature appropriated 10,000 dollars for the restoration of the San Diego Mission, ${ }^{125}$ resulting in an unquestionable financial benefit of a strictly religious nature to the Roman Catholic Churcl, which owned and controlled the mission for the use of its parishioners. There was also an independent primary secular effect, however, in no way derived from the religious impact of the action, which could not be fairly characterized as a nere "cover." As the court noted, the missions have significant architectural, historical, and educational value, and the aid therefore served a secular esthetic purpose. Under the proposed analysis, this should generally be adequate to establish constitutional validity. ${ }^{120}$ It might be added, as a persuasive rather than a constitutional argument, ${ }^{127}$ that it is reasonable to believe that reconditioning the mission would pay financial dividends to the state treasury, by increased tourism, in excess of its cost. The mission case thus involved no possible infringement

117 But see Hammett, supra note 106, at 932. See also Note, The Elementary and Secondary Education Act of 1965 and the First Amendment, 41 IND. L.J. 302, 324 (1966).

118 See text accompanying note 447 infra.

118 Zorach v. Clauson, 343 U.S. 306, 314 (1952) (Douglas, J.).

120 See Choper, supra note 4, at 335.

121 But see Hammett, supra note 106, at 932.

122 See, e.g., School Dist. v. Schempp, 374 U.S. 203, 223-25 (1963). See text following note 231 infra.

${ }^{123}$ LaNoue, supra note 60, at 77-78.

124 See generally Van Alstyne, supra note 68, at 876-77.

125 Frohligher v. Richardson, 63 Cal. App. 209, 218 P. 497 (1923).

126 The California court, however, found the action violative of the state constitution. 127 See text following note 158 infra. 
of religious or conscientious scruples, either directly or through diversion of tax funds to religious purposes. ${ }^{128}$

A municipality should not, lowever, be permitted to allocate public funds to build houses of worship for the purpose of encouraging churclgoing people to live in the community. In contrast to the mission restoration example discussed above, which attracted people by appeahing to their esthetic and educational interests, this plan would publicly finance the religious needs of individuals in order ultimately to derive a secular goal. Even though the plan miglit increase the general tax base in the community, ${ }^{129}$ thus compensating the public for its religious expenditure, its primary effect-from which the secular end would be derivedwould be religious. ${ }^{130}$

Finally, it has been suggested that, as part of a state's mental health budget, funds might be granted to the Roman Catholic Church and the Protestant Episcopal Cluurch to subsidize confession costs because of their therapeutic value. ${ }^{131}$ But it would seem here that the purported therapeutic benefit-which we may concede is secular-would come about only as a result of the confessor's having obtained spiritual satisfaction. The exclusive primary effect is religious. ${ }^{132}$

\section{Supreme Court Rationale}

The rather specific rationale of several decisions of the Supreme Court is consistent with this "secular purpose" approach. In the School Bus Case, ${ }^{133}$ the Court acknowledged that the governmental program substantially benefitted religion in the "possibility that some of the children might not be sent to the church schools if the parents were com-

128 Similarly, an expenditure by the Utah legislature to construct a building for the preservation and display of relics, highly important to the Mormon religion but also of great historical significance in the state's development, serves an independent primary secular goal. See Thomas v. Daughters of Utah Pioneers, 114 Utah 108, 197 P.2d 477 (1948). So, too, would an appropriation by the Los Angeles County Board of Supervisors to a religious association for the purpose of preparing a motion picture film of the latter's annual sectarianoriented Christmas parade, if the film were to be distributed throughout the country "to exploit and make known the resources of the County and thereby increase its trade and commerce." County of Los Angeles v. Hollinger, 221 Cal. App. 2d 154, 156, 34 Cal. Rptr. 387, 389 (1963) (invalid under state constitution). See also 37 OP. CaL. Atr'y Gen. 105 (1965).

129 Murray v. Comptroller of the Treasury, 241 Md. 383, 402-04, 216 A.2d 897, 908-09, cert. denied, 385 U.S. 816 (1966).

130 See text following note 158 infra.

131 Davidow, Governmental Aid to Church-Afiliated Colleges: An Analysis of a Possible Answer to the Constitutional Question, 43 N.D.I. REv. 659, 679 (1967).

132 This should be contrasted with public aid to divinity schools to train students to recognize mental illness. See U.S. Dep't of Health, Education \& Welfare, supra note 20, at 375-76 n.18.

133 Everson v. Board of Educ., 330 U.S. 1 (1947). 
pelled to pay their children's bus fares out of their own pockets when transportation to a public school would have been paid for by the State."1134 Yet, the Court upheld public payment of the bus fares of parochial school pupils as "public welfare legislation" protecting "children going to and from church scliools from the very real hazards of traffic."130 There was a legitimate independent primary secular purpose and effect. ${ }^{180}$ The Court utilized the same analysis in the Sunday Closing Law Case, ${ }^{187}$ recognizing that the establishment clause "does not ban federal or state regulation of conduct whose reason or effect merely happens to coincide or harmonize with the tenets of some or all rehgions."'188

In the Bible Reading Case, ${ }^{138}$ the Court was most explicit. It laid down a "test" as follows: "what are the purpose and primary effect of the enactment? If either is the advancement or inhibition of rehgion then the enactment exceeds the scope of legislative power as circumscribed by the Constitution. That is to say that to withstand the strictures of the Establishment Clause there must be a secular legislative purpose and a primary effect that neither advances nor inhibits religion."1140

If the Court meant that there is an establishment clause violation if the purpose and primary effect is religious but that there is no such violation if $a$ secular legislative purpose and primary effect exists, and if the Court used the word "primary" as I have used it in the discussion above- that is, as distinguished from "ultimate" or "derivative" the Court's test essentially states the reasoning that I have employed. ${ }^{142}$

In fairness, this places undue weight on tiny words which usually denote no such significance. The Court may perhaps have drafted the test not for the specific situation in Schempp, but for the question of aid

$134 I d$, at 17.

$135 \mathrm{Id}$. at 16-17.

136 See note 510 infra; Comment, 45 MICH. L. REv, 1001, 1021 n.89 (1947).

137 McGowan v. Maryland, 366 U.S. 420 (1961).

$138 I d$. at 442 . Neither, it would seem, should the clause ban "federal or state [financial aid] whose reason or effect merely happens to coincide or harmonize with" the aims of some or all religions, if a primary effect of such aid is for "the general welfare of society," Id.

139 School Dist. v. Schempp, 374 U.S. 203 (1963).

140 Id. at 222 .

141 Mr. Hammett argues, supra note 106, at 933, that the Court's intention on this point was to assure that the enactment does not enhance the financial strength of the church to a greater extent than it augments the influence of or benefit to the state. How the Court is to measure these relative increases in power is not clear. He may mean, as $I$ have suggested, that there must be an independent secular benefit commensurate with the statc aid. But if he means that the members of the Court must individually weigh these church and state factors in each case, then serious objection may be raised. See text accompanying notes 117-20 supra.

142 For support of this view, see Kauper, supra note 18, at 12-13. See also Kauper, Religion, Higher Education and the Constitution, 19 ALs. L. REv. 275, 288 (1967). 
to parochial schools. ${ }^{143}$ Even so, because of differing inferences that may be drawn, it provides no ready answer. Perhaps, on the other hand, the Court was concerned only with the problem before it. ${ }^{144}$ In any case, my only contention is that the Schempp "test" is not inconsonant with the "secular purpose" approach proposed herein.

TV

\section{AID TO PAROCHIAI SCHOOLS}

\section{A. Secular Purpose}

At least some governmental aid to support parochial education serves a primary or independent secular purpose. No one can deny the state's legitimate interest in improving the educational quality of all schools, ${ }^{145}$ or the benefits to society in general from education, ${ }^{146}$ or even the national defense interest in an enlightened citizenry. ${ }^{147}$ The fact is that "parochial elementary and secondary schools educate one out of every eight future citizens of this country, and that the teacher and classroom needs of parochial school systems are possibly even more serious than are those of the public school systems."1148

Even Mr. Justice Rutledge, in his vigorous dissent in Everson, admitted that "it is much too late to urge that legislation designed to facilitate the opportumities of children to secure a secular education serves no public purpose."149 His position was that the establishment clause

143 Sky, supra note 42 , at 1441.

144 See Horace Mann League v. Board of Pub. Works, 242 Md. 645, 220 A.2d 51, 64, cert. dentied, 385 U.S. 97 (1966); LaNoue, supra note 60, at 78-79.

145 Board of Educ. v. Allen, 20 N.Y.2d 109, 116, 228 N.E.2d 791, 794, 281 N.Y.S.2d 799, 804 (1967), prob. juris. noted, 36 U.S.L.W. 3278 (U.S. Jan. 15, 1968). See also Amdursky, The First Amendment and Federal Aid to Church-Related Schools, 17 SYracuse L. Rev. 609,624 (1966).

146 Malloy, How to Talk About Federal Aid, 105 AxrERTCA 421, 422 (1962).

147 Sky, supra note 42 , at 1448.

148 Actions of the General Assembly of the United Presbyterian Church in the U.S.A. Supporting Federal Aid to Public Primary and Secondary Education, in 5 Hearings on $S$. 370 Before the Subcomm. on Education of the Senate Comm. on Labor and Public Welfare, 89th Cong., 1st Sess., at 2890 (1965). It is not the purpose here to document the alleged need of parochial schools for financial assistance. But several interesting facts night be mentioned: (a) The U.S. Commissioner of Education recently observed that "[a]t all levels of education, effective teaching has becone increasingly contingent on well-stocked libraries. . .." $2 \mathrm{id}$. at 848 . His statistics revealed that $29.6 \%$ of public school pupils and $37.2 \%$ of nonpublic school pupils attended schools that had no libraries. Id. at 849 . (b) Children from "deprived neigliborhoods" attending both public and parochial schools "are losing points on their IQ, particularly between the third and sixth grades, and by the time they get to the eighth grade, they are apt to be 2 or 3 or 4 or 5 years behind." 5 id. at 2540 (question by Senator Robert F. Kennedy).

149330 U.S. at 50. 
forbids state support for "religious training, teaching or observance."150 I agree. But, "[i]f the fact alone be determinative that religious schools are engaged in education," he could "see no possible basis, except one of dubious legislative policy, for the state's refusal to make full appropriation for support of private, religious schools, just as is done for public instruction. ${ }^{1151}$ I disagree.

Parochial schools perform a dual function, providing some religious education and some secular education. Government may finance the latter, ${ }^{152}$ but the establishment clause forbids it to finance the former. That government money may be used for partial support of church schools does not mean that "it can also be used for the support of our churches, and that we are moving toward a union of church and state in America."153 Conceding Mr. Justice Jackson's premise that "Catholic education is the rock on which the whole structure rests," $" 154$ his conclusion does not follow that rendering "tax aid to its Church school is indistinguishable . . . from rendering the same aid to the Church itself."

It must be perceived that by using tax funds to support the secular aspects of parochial education, the state expends no more than would be required either to support parochial school pupils if they attended existing public schools, or to establish additional public schools at various sites for all pupils presently attending parochial schools, neither of which alternatives raises colorable constitutional objection. This point is not made to prove that either the free exercise clause or political fairness demands governunent aid for parochial schools. Rather, it demonstrates that, where the state affords public money to finance the secular aspects of education in church-related schools, it imposes a tax burden essentially identical with that which it could constitutionally impose for separate secular facilities. To do so in no way violates the historical and contemporary pohicy underlying the establishment clause against infringing religious biberty through taxation for religious purposes. ${ }^{156}$

150 Id. at 52 .

151 Id. at 49-50. Justice O'Connell makes a similar contention in Dickman v. School Dist., 232 Ore. 238, 255-56, 366 P.2d 533, 542 (1961), cert. denied, 371 U.S. 823 (1962).

152 This is considered in detail in text accompanying notes 200-80 infra.

153 A. Jornson \& F. Yosx, supra note 28 , at 151.

154 Everson v. Board of Educ., 330 U.S. 1, 24 (1947) (dissenting opinion of Jackson, J.). 155 See Snapper, Contributions of Independent Fiducation, in Educatronat Freedom 103, 104-05 (D. McGarry \& L. Ward eds. 1966) ; cf. Freeman, Tax Credits and the School Aid Deadlock, 194 CATHOIIC WoRID 201, 203 (1962).

156 Thus, Professor Sutherland could write of a proposal granting limited aid to parochial education that it "would not impair any person's free exercise of rehigion, it would have to be judged as a question of 'ultra vires.' " Letter to Senator Morse, in S. Doc. No. 29, 87th Cong., 1st Sess. 52, 61 (1961). See also Corley, Objection to Aid Answered, in Edu- 
In addition, it is possible that, by affording some state aid to nonpublic schools (but substantially less than the per capita public school cost) ${ }_{1}^{157}$ a net decrease in the tax burden would result; a number of nonpublic pupils who are now shifting to public schools for economic reasons might cease doing so and, as is frequently predicted, many public school children might transfer to parochial or private schools. ${ }^{158}$ Of course, this latter argument is not of constitutional scope, because a net increase in tax burden should be equally constitutional if the public aid were limited to the secular aspects of education in parochial schools. Nor could government finance religion in the hope, or even with the assurance, that it would in some way produce a smaller overall tax burden. Economically, the argument is appealing. Constitutionally, however, I know of no dissent from the proposition that it would be a patent use of rehigion as an engine of civil policy in violation of the establishment clause.

\section{B. Discrimination Among Recipient Schools}

The proposal contained in this article assumes that any governmental aid will be extended to parochial schools on a constitutionally nondiscriminatory basis. For the legislature to single out, say, Lutheran parochial schools or their students for aid, while refusing to afford equal privilege to other similarly situated cliurch-related or private schools, would be a patent violation of the establishment clause, as would giving aid only to church-related schools while denying it to others similarly situated. The former action would "prefer one rehioion over another."159 The latter would "aid all religions as agaimst non-believers."160

This is not to say that if aid is to be extended beyond the realm of public schools it must be afforded nondiscriminatorily to all nonpublic schools. The statute in the Everson case itself distinguished between nonpublic schools "operated for profit in whole or in part"161 and those that were not, as does Title III of the Elementary and Secondary Education Act of $1965 .^{162}$ Such a classification, not based on religion, should not

catronar Freedour 184, 186 (D. McGarry \& L. Ward eds. 1966). But see Editorial, . . . And in Maryland, Washington Post, Oct. 11, 1967, at A 16, col. 1.

157 Calculation and allocation of costs in parochial schools that may be publicly financed is discussed in text accompanying notes 200-84 infra.

158 See McDonough, Economy of Government Aid to Independent Education: A Taxpayers' Savings Plan, in Educatronar Freedom 122 (D. McGarry \& L. Ward eds. 1966).

159 Everson v. Board of Educ., 330 U.S. 1, 15 (1947).

160 Torcaso v. Watkins, 367 U.S. 488, 495 (1961). See also Tarshis v. New York, 24 App. Div. 2d 644, 262 N.Y.S.2d 538 (1965). But cf. Packer Collegiate Institute v. Umversity of State of N.Y., 273 App. Div. 203, 208-09, 76 N.Y.S.2d 499, 505 (1948).

161330 U.S. 1, 3 n.1 (1947).

16220 U.S.C. $\$ \$ 841,843$ (b) (5) (Supp. I, 1965). 
violate the establishment clause. ${ }^{103}$ Nor, despite suggestions to the contrary ${ }^{104}$ should such an economic differentiation be lield to contravene the equal protection clause of the fourteenth amendment. ${ }^{165}$ Perhaps wealth is "a capricious or irrelevant factor" to measure a voter's qualifications $^{100}$ or to determine certain rights of those accused of crime..$^{107} \mathrm{But}$ surely it is not such a factor for the purpose of distribution of public largesse. It has been suggested that equal protection forbids discrimination both for and against Negroes, ${ }^{108}$ but never seriously that it makes poverty an equally neutral factor. ${ }^{169}$

It is true that this profit-nonprofit classification turns on the character of the school, which is the immediate recipient of the aid, rather than on the particular needs of each child in attendance, and that some needy students will be enrolled in schools operated for profit while some affluent children will be registered in nonprofit institutions. ${ }^{170}$ Although a more perfect system might look to the individual child rather than base its judgment on the assumption that nonprofit schools educate more needy children, ${ }^{171}$ this would be much more difficult to administer. ${ }^{172}$ In the context of an essentially economic classification, ${ }^{173}$ equal protection "is offended only if the classification rests on grounds wholly irrelevant to the achievement of the State's objective." "174 "It is by ... practical con-

${ }^{103}$ See Kurland, supra note 19, at 70. Contra, Stout, The Establishment of Religion Under the Constitution, $37 \mathrm{Kx}$. L.J. 220, 231-32 (1949). However, if the amount of aid given to a parochial school within this classification exceeds the value of the secular educational service it renders, the establishment clause would be violated under the terms of the proposal advanced in this article.

164 See Comment, The School Bus Law: Transportation of Parochial and Private School Pupils in Pennsylvania, 27 U. PITT. I. Rev. 71, 79 (1965). The statute in Everson was not attacked on this ground, but the Court indicated that such a challenge might not be wholly frivolous, 330 U.S. at $4 \mathrm{n} .4,4-5$; see Comment, Constitutional Law-Establishment of Religion, Due Process, and Equal Protection-Public Aid to Parochial Schools, 45 MrCr. I. REv. 1001, 1014 (1947).

$165 \mathrm{Or}$, in the case of a federal statute, the due process clause of the fifth amendment. See Bolling v. Sharpe, 347 U.S. 497 (1954).

106 Harper v. Virginia Bd. of Elections, 383 U.S. 663, 668 (1966).

107 See Douglas v. California, 372 U.S. 353 (1963); Griffin v. Illinois, 351 U.S. 12 (1956).

108 See Kaplan, Segregation Litigation and the Schools-Part II: The General Northern Problem, 58 Nw. U.L. Rev. 157 (1963).

169 But cf. Edwards v. California, 314 U.S. 160, 184-85 (1941) (concurring opinion of Jackson, J.).

170 See Everson v. Board of Educ., 330 U.S. 1, 20-21 (1947) (dissenting opinion of Jackson, J.); id. at $62 \mathrm{n} .58$ (dissenting opinion of Rutledge, J.); Allen \& Marshall, "Child Benefit" Has Lost Its Glitter, 44 P\#I DetTa Kappan 77, 78 (1962).

171 See 5 Hearings on S. 370, supra note 148, at 2895 (Statement of Lawrence Speiser, Director, ACLU).

172 See T. Powetr, The Screor Bus Law 75 (1960).

173 But cf. Horowitz, Unseparate but Unequal-The Emerging Fourteenth Amendment Issue in Public School Education, 13 U.C.L.A.I. REv. 1147 (1966).

174 McGowan v. Maryland, 366 U.S. 420, 425 (1961). 
siderations based on experience rather than by theoretical inconsistencies that the question of equal protection is to be answered."175

Statutes constitutionally neutral on their face, however, may be invalid in effect. ${ }^{176}$ Under a proper statutory definition, for example, the only "nonprofit" school in town may be a parochial school. Absent a judicial finding that the legitimate statutory definition merely camouflaged an illegitimate preference of rehgion violating the establishment clause, ${ }^{177}$ the statute should not be held invalid. A public appropriation for a primary secular purpose should not be void merely because, under an appropriate neutral standard, a religiously controlled institution happens to be the only recipient. ${ }^{178}$

A more difficult issue, but one apparently of no great consequence, arises where an aid statute by its terms names the parochial schools of one church only, or names only parochial schools, and it is unknown from the statute or its available legislative history whether other similarly situated schools exist. 179 The Court could: (a) strike down the statute, thus forcing the legislature to redraft properly if it can; ${ }^{180}$ (b) strike down the statute, unless it were shown that there were no others similarly situated; ${ }^{181}$ (c) uphold the statute, unless it were shown that there were others similarly situated. ${ }^{182}$

\section{The Compensable Amount}

The constitutional principle proposed herein speaks of the secular educational services rendered by the church-affiliated school. Assuming that these services may be isolated, ${ }^{183}$ little difficulty arises where their cost is the same to the parochial school as to the public school system. Because government may properly finance the secular education of all

175 Railway Express Agency v. New York, 336 U.S. 106, 110 (1949). See Rhoades v. School Dist., 424 Pa. 202, 225, 226 A.2d 53, 66, appeal dismissed per curiam, 389 U.S. 11 (1967).

176 See Lane v. Wilson, 307 U.S. 268 (1939).

177 Herein, the question of "motive." See text at notes 114-24 supra; W. LOckHART, Y. Kamtisar \& J. Choper, Constitutional Law 1209 (2d ed. 1967). For an example, see State ex rel. Reynolds v. Nusbaum, 17 Wis. 2d 148, 158, 115 N.W.2d 761, 766 (1962).

178 See Kintzele v. City of St. Louis, 347 S.W.2d 695 (Mo. 1961) (redevelopment authority gave benefit to university, within relevant geographic area, which happened to be religiously affiliated). See also 79 CHRISTIAN CENTURY 1057 (1962) (editorial); 78 id. at 1135 (1961) (editorial).

170 This was in fact the situation in Everson. The township resolution authorized reimbursement only for parents of public and Catholic schools pupils. 330 U.S. at 4 n.2.

180 See id. at 21 (dissenting opinion of Jackson, J.) ; cf. McLeod v. J.E. Dilworth Co., 322 U.S. 327 (1944).

181 Everson v. Board of Educ., 330 U.S. 1, 62-63 n.61 (1947) (dissenting opinion of Rutledge, J.).

182 This is the action the Everson Court took. Id. at 4 n.2.

183 For discussion of this issue, see text accompanying notes 200-284 infra. 
children, whatever their religious faith, payment to a parochial school under these circumstances of the same amount that sucl education costs in the public schools should be immune from establishment clause protest: No tax funds are being expended for strictly rehious purposes; no more tax funds are being used than would be if the pupils were in public scliools; ${ }^{184}$ the churcli obtains no financial benefit except compensation for the cost of secular services rendered. ${ }^{185} \mathrm{~A}$ fortiori, there is no difficulty if the cost of providing this service in the parochial school is less than it is in the public school system, as is not unlikely, and government pays the parochial school only this lesser amount.

But suppose that the cost of providing secular educational services in the parochial scliool is less than is the cost in the public school system and government pays the parochial scliool the latter amount. ${ }^{180}$ Although here also no more tax funds are being expended than would be if the pupils were in public schools, the church obtains a net financial benefit. Nevertheless, this should not violate the establishment clause. Literally thousands of church-related agencies offer secular services that are funded-or purchased, if you will-by government. ${ }^{187}$ If any organization-profit or nonprofit, religious or nonsectarian-provides a secular service to government at the "going rate," and is able to profit thereby" because of low labor costs, efficiency, or any otlier reason, the Constitution should not be held to prohibit it. ${ }^{188}$ In fact, for government to refuse

$184 C f$. Cook County v. Chicago Indus. School for Girls, 125 Ill. 540, 569-71, 18 N.E. 183, 196-97 (1888).

185 See Schade v. Allegheny County Institution Dist., 386 Pa. 507, 512, 126 A.2d 911, 914 (1956); Cushman, Public Support of Religious Education in American Constitutional Law, 45 Irr. L. REv. 333, 336 (1950). It may not be denied that the public financing may permit the church now to use funds formerly spent for secular educational purposes for strictly religious purposes. This "freed funds" issue, whose effect is irrelevant to the rationale proposed herein and is produced by every concededly valid direct or indirect public aid to religiously-affiliated institutions, is further considered at text accompanying notes 407-15 infra. Neither may it be demed that, as a result of this governmental action, the church will be significantly aided in a nonfinancial way, for gaining attendants at parochial schools "is a powerful instrumentality in the successful prosecution of the work of [inany churches]." Bennett v. City of La Grange, 153 Ga. 428, 437, 112 S.E. 482, 486-87 (1922). But, since the government's action has a primary secular effect, the equally present benefit to religion should not invalidate it. See text following note 111 supra.

186 Cf. 2 U.S.C. $\$ 88 \mathrm{a}$ (c) (1964), providing that congressional pages may "attend a private or parochial school of their own choice" and that "such . . . school shall be reimbursed" by Congress "in the same amount as would be paid if the page or pages were attending a public school."

187 See R. DrITAN, supra note 50, at 27. See also Hammett, sulpra note 106, at 936.

188 Thus, a religiously-affiliated institution may be the successful bidder in a redevelopment project, satisfying a valid public purpose, and this should not violate the establishment clause because the institution thereby acquired valuable property at a lower price than it would lave had to pay by negotiation with the private owners, who got full value for the property from the public rẹdevelopment authority. See Eḷiș v. City of Grand Rapids, 257 
to deal on equal terms with an organization providing public services because that organization is religiously-affiliated miglit even be seen as a violation of the free exercise clause.

It must be recalled that government assistance to religion which neither infringes religious liberty nor expends tax funds for strictly religious purposes should not be considered violative of the establisliment bar. ${ }^{189}$ Thus, in the context of the immediate discussion, it is the "cost" to the public and not the "aid" to religion that is determinative. ${ }^{190}$ As long as the government receives in full the secular services purcliased, the relative cost or profit to rehioion of supplying those services should have no relevance to the establisliment clause. Its prohibition should be satisfied by a slowing that the government is getting the secular services it paid for. Consequently, where something costs the government hittle or nothing, it should make no difference what secular services it receives. For example, the government may allow religious organizations temporarily to use vacant public buildings for strictly religious purposes. Such occasional use of public buildings may substantially "aid" religious groups, and it may save them significant rental fees. But, if the use is not "regular and extended in duration,"191 the "cost" to the public is mil or de mimimis, ${ }^{192}$ and there should be no establishment breacli. ${ }^{193}$ It may be argued that, even though the use of the building cost the state nothing, it could charge these religious organizations measurable rental fees. But the establishment clause should not require that government profit at religion's expense. It should merely forbid public expenditures for strictly rehgious purposes.

Therefore, if the government lends money at a rate of interest equal to or above the government borrowing rate but below the commercial

F. Supp. 564, 569-70 (W.D. Mich. 1966) ; 64th St. Residences, Inc. v. City of New York, 4 N.Y.2d 268, 150 N.E.2d 396, 174 N.Y.S.2d 1 (1958). See also Adams v. County Comm'rs, 180 Md. 550, 26 A.2d 377, 380 (1942).

189 See text accompanying notes 43-50, 79-80 supra.

190 But cf. McVey v. Hawkins, 364 Mo. 44, 54, 258 S.W.2d 927, 932-33 (1953).

$191 \mathrm{~L}$. PFEFFER, supra note 26 , at 207.

192 See note 53 supra. But cf. Engel v. Vitale, 370 U.S. 421, 441 (1962) (concurring opinion of Douglas, J.).

193 See Southside Estates Baptist Church v. Board of Trustees, 115 So. 2d 697 (Fla. 1959); Nichols v. School Directors, 93 Ml. 61, 34 Am. Rep. 160 (1879); State ex rel. Gilbert v. Dilley, 95 Neb. 527, 145 N.W. 999 (1914); People ex rel. Lewis v. Graves, 219 App. Div. 233, 236, 219 N.Y.S. 189,192 (1927).

Similarly, if public funds were used to construct a research laboratory on the campus of a church-affiliated university, and the building were used for this purpose to the extent contemplated and demanded by the research project, the full secular purpose that the state bargained for will have been achieved. This being so, even a regular use of these facilities (say, on evenings or weekends) by the school for religious purposes should be valid. But see Kratz, Research and Service Programs and Public Funds in the Church-Related School, 7 J. Church \& Sr. 207, 211-12 (1965). 
rate, it may so lend to sectarian groups, even though they use the money for strictly religious purposes. The church benefits, but at no cost to the state. This should not be confused with government loans for secular purposes. ${ }^{194}$ Since, as to these, grants would be unobjectionable, loans at any rate are obviously valid. ${ }^{195}$ It follows that a state may buy textbooks-even religious ones-at quantity prices and sell them to parochial schools at the discounted price.

Finally, suppose that the cost of providing secular educational services in the parochial school exceeds the cost in the public school system ${ }^{100}$ and government pays the parochial school the former amount. Although the church here does not obtain funds that may be used for strictly religious purposes, more tax funds are being expended than would be if the children were in public schools. There should, nonetheless, be no violation of the establishment clause. ${ }^{197}$ So long as the state expenditure is in fact for a prinary secular goal, ${ }^{198}$ no tax funds are being used for strictly religious purposes. ${ }^{199}$

194 See Hayes, supra note 10, at 174. See also provisions of the Housing Act of 1950, 64 Stat. 77, 12 U.S.C. $\$ 1749$ (1964); the National Defense Education Act of 1958, 20 U.S.C. \$\$ 421-29 (1964).

105 The National Defense Education Act of 1958, 20 U.S.C. $₹ 445$ (b)(3) (1964) sets the interest rate for loans to nonprofit private schools at one fourth of $1 \%$ above the average government borrowing rate.

106 This might result because the marginal additional cost of adding even all the parochial students to the public schools could well be less than the cost of duplicative facilities in the parochial school. Or the per capita cost of transportation for parochial school students might be higher. See Hearings on $H . R .13160$ and $H . R .13161$ Before the General Subcomm. on Education of the House Comm. on Education and Labor, 89th Cong., 2d Sess, at 56 (1966).

197 Contra, 5 Hearings on S. 370, supra note 148, at 2896 (statement of Lawrence Speiser, Director, ACLU).

198 In fact, an additional secular purpose might be advanced in that, even though there may be duplicative facilities, there is an educational advantage in smaller classes and diversified and experimental techniques and programs-although the diversified style may not be such as to produce religious rather than secular education, sce text accompanying notes 200-80 infra-see Snapper, supra note 155, at 106-07.

109 See text accompanying note 155 supra.

The entire discussion assumes that the total funds provided by all levels of governmentfederal, state, and local-including the value of tax exemptions (and such benefits as preferential mailing rates, see Weclew, Church and State: How Much Separation?, 10 DE PAUL L. REv. 1, 23-24 (1960)) given parochial school property and activity, will not exceed the cost of the secular educational services rendered by the church-affiliated school. The general topic of tax exemptions for church property and religious activities is beyond the scope of this discussion. But brief reference to certain aspects of the problem may be helpful.

There appears to be no analytically meaningful way to distinguish a tax exemption from a direct subsidy. Exemptions afford financial benefits and increase the tax burden of others. Murray v. Comptroller of Treasury, $241 \mathrm{Md}$. 399, 216 A.2d 897, 906, cert. denied, 385 U.S. 816 (1966). But see Snyder v. Town of Newtown, 147 Conn. 397, 161 A.2d 770, 781 (1960) (dissenting opinion) (1960), appeal dismissed, 365 U.S. 299 (1961); cf. Everson v. Board of Educ., 330 U.S. 1, 61 n.57 (1947) (dissenting opinion of Rutledge, J.). Unlike the sporadic 


\section{The Permeation Issue}

\section{The Facts}

Probably the most complex matter concerning public financial assistance to parochial education is the permeation (or integration) issue. It is frequently contended that "official Catholic doctrine refuses to recognize any distinction between secular and religious teaching." ${ }^{200}$ Pope

church use of public buildings, see text accompanying notes 189-93 supra, tax exemption thus clearly results in out-of-pocket cost to taxpayers. It may be true that by tax exemption "the state inerely refrains from diverting to its own uses income independently generated by the churches through voluntary contributions." Giannella, Religious Liberty, Nonestablisliment and Doctrinal Development-Part II. The Nonestablishment Principle, 81 Harv. I. REv. 513, 553 (1968). But, by augmenting the assessment on others, tax exemption effectively "forcibly diverts the income of both believers and nonbelievers to churches." Id. Thus, in reference to governmental financial assistance to parochial education, tax exemptions must be computed with other funds provided. But cf. Iundberg v. County of Alameda, 46 Cal. 2d 644, 298 P.2d 1, appeal dismissed sub nom. Heisy v. County of Alameda, 352 U.S. 921 (1956).

It has been said that, "No entirely satisfactory rationale for tax exemption has ever been stated in any American judicial decision," R. DrnNaN, supra note 50, at 9, and its constitutionality has been seriousiy questioned. Korbel, Do the Federal Income Tax Laws Involve an "Establishment of Religion"?, 53 A.B.A.J. 1018 (1967). But see General Finance Corp. v. Archetto, 93 R.T. 392, 176 A.2d 73 (1961), appeal dismissed, 369 U.S. 423 (1962). There is some indication that, at least in some forms, the Court considers it required by the free exercise clause. See Follett v. McCormick, 321 U.S. 573 (1944); Murdock v. Pennsylvania, 319 U.S. 105 (1943). When afforded to church or synagogue buildings themselves, perhaps it is justified as "compensation" for the public welfare (purely secular) services performed by these religious organizations. See Murray v. Comptroller of Treasury, $241 \mathrm{Md}$. 383, 401-02, 216 A.2d 897, 907-08, cert. denied, 385 U.S. 816 (1966); Kauper, supra note 84, at 97, 108, 112-13. For an excellent general discussion, see Kauper, supra note 84; see also Note, 61 Nw. U.L. REv. 777, 787-93 (1966).

Professor Van Alstyne has introduced an extremely provocative and penetrating consideration, which logically goes not only to justification of "tax accommodations [for religion] which currently exist in many state and federal laws," Van Alstyne, supra note 68, at 882 , but is relevant also to the entire question of expenditure of public funds in aid of religion. He observes that "as more of the economy and environment is occupied by the increasing public, governmental sector of our society, the net effect of the shift is to confine religion to the ever shrinking doman of the relatively diminishing private sector," and that "to the extent that the tax revenues thus collected may not be spent by government to support religious enterprises, but must be used exclusively for secular purposes, the net effect, arguably, is to reduce the relative supply of funds available to religion." Id. at 881.

Professor Giannella amplifies this point in advancing, as central to his thesis, that "the no-aid aspects of the separation principle should be relaxed in direct proportion to the extent of governmental regulation." Giannella, supra at 522. See generally id. at 522-26, 537-55.

The rationale is indeed an intriguing one and unquestionably merits further exploration. But, like others, "Once loosed, the idea ... is not easily cabined." Cox, Foreword: Constitutional Adjudication and the Promotion of Human Rights, 80 EAARv. L. Rev. 91 (1966). Apart from judicial limitations that are essentially intuitive and involve "large and imponderable factors," Giannella, supra at 527, it would suggest that government literally unay finance many strictly sectarian efforts of organized religion. It is seemingly a thesis demanding extensive, if not total, reevaluation of the broadly conceived establishment clause goals in light of changed and changing circumstances.

200 Konvitz, Separation of Church and State: The First Freedom, 14 LAw \& CoNTEMP. 
Pius XI and Pope Leo XIII are quoted as ordering "that every ... subject taught, be permeated with Christian piety,"201 as are Catholic educators, theologians and philosophers. ${ }^{202} \mathrm{~A}$ Lutheran school manual demands "that all areas of the curriculum reflect an adequate philosophy of Christian education."203 Seventh Day Adventists declare their "endeavor to permeate all branches of learning with a spiritual outlook."204 After all, it is asked, "if religion is taught only one or two hours a day in church schools, what is the point of maintaining the separate parochial scliool system?"205

But there is less than universal agreement as to the facts. Others familiar with Catholic-and Jewislı ${ }^{206}$-parochial school education explam that the pupil there "learns essentially the same arithmetic, spelling, English, history, civics, foreign languages, geography, and science" as is taught in the public schools, but in addition learns religion "and the religious dimensions of secular knowledge." ${ }^{207}$ In the Lutheran school sys-

Prob. 44, 58 (1949). See also Konvitz, Whittling Away Religious Freedom, ConacantaRY, June 1946 , at $4,6-7$.

201 Konvitz, Separation of Church and State: The First Freedom, 14 LAw \& ConTEMP. Prob. 44, 58 (1949). See also Drinan, Should the State Aid Private Schools?, 37 ConN. B.J. 361, 366 (1963); Hayes, Law and the Parochial School: A Formulation of Conflicting Positions, 3 Catholic LAw. 99, 100 (1957); Slough \& McAnany, supra note 37, at 61-62.

202 See A. Stokes \& L. Prefrer, supra note 27, at 444; Pfeffer, Religion, Education and the Constitution, 8 LAw. Gund REv. 387, 396 (1948); Hearings on H.R. 6074 Before the Ad Hoc Subcomm. on Study of Shared-Time Education of the House Comm. on Education and Labor, 88th Cong., 2d Sess., at 55 (1964).

203 Quoted in G. LANouE, supra note 56 , at 31.

204 Id.

205 Id. See also Gordis, Education for a Nation of Nations, in Religion and the Schools, supra note 37 , at $5,23$.

206 See paper by Dr. Nichols, summarized in Religion and Freedom 22 (Report by D. McDonald on a Seminar sponsored by the Fund for the Republic, New York, N.Y., May 5-9, 1958); Gilbert, Symposium: Shared Time, 57 Recicious Evoc. 14, 15 (1962). But see Brickman, id. at 20,21 , who says that some Jewish parochial school leaders would object to their students taking courses in literature, science, and social studies outside of the Hebrew day school because they "should not be exposed in secular courses to any heterodox or heretical ideas or doctrines."

207 National Catholic Welfare Conference, supra note 37, at 408. See also McCluskey, A Changing Pattern, in FEDERAL AID AND CATHodic ScHools 31, 39-40 (D. Callahan ed. 1964); Copass, Church Schools Have No Claim on Public Funds, Nation's Schoors, Aug. 1945, at 29; Coughlan, Religion and the Schools, LIFE, June 16, 1961, at 110, 122 ; D'Amour, Tempest in a Textbook, 107 Ascerica 443 (1962); Hayes, supra note 10, at 176; Kauper, supra note 35, at 36; Williams, Should the Federal Government Aid Parochial Schools, 111 ForUM 100 (1949). The following statement illustrates the point well: "The Christian teacher of the law, therefore, slould know the positive legal fact, but he inust also have some concern for the law as an expression of justice. The Christian biologist must know the facts of evolution, but he must also be aware of theological discussion of human creation. The Christian physicist must know his nuclear science, but he must be aware that its applications have had a social and ultimately inoral impact on the whole world." Fidelian, Christian Schools, Secular Subjects, 81 Commonwear 566, 568 (1965). 
tem, it is said that "the main features of the public school curriculum are reproduced." In response to a study showing that many "secular course" textbooks used in parochial schools are permeated with religious symbols, concepts, and doctrines, ${ }^{209}$ it has been said that the examples "were highly arbitrary and not representative," and that "Catholic educators ... as a whole, do not favor textbooks in which dabs of spurious religion serve only to distort the essential subject matter. . . ."210

Further evidence that secular subjects in parochial sclools need be little different than their counterpart public school offerings is found in the fact that, as part of shared time programs, many parochial school students actually take such courses as mathematics, physics, science, foreign languages, music, industrial arts, home economics, and physical education in the public school itself. ${ }^{211}$ Catholic educators have observed that "basic instruction" in such courses as literature and history could well be undertaken in shared time programs in the public schools "with the cluurcl adding the distinctive note which it can bear to the revelation

A teacher's manual for a mathematics text prepared for use in Catholic schools begins by pointing out that "the authors ... have recognized that first and foremost, an arithmetic program for Catholic schools must be mathematically sound. Over and above this, they have recognized that ... these situations present opportunities for the exercise of Christian virtues." LaNoue, Religious Schools and "Secular" Subjects, 32 Harv. Educ. Rev. 255,274 (1962).

208 A. Stozes \& I. Pfefrer, supra note 27, at 419. Lutheran teachers are instructed to "constantly search for materials that can be correlated with basic texts," LaNoue, supra note 207 , at 281 , thus implying that religious values are added to basic secular instruction.

200 See discussion accompanying note 207 supra and notes 252-278 infra.

210 Ball, Federal Aid-1964, 61 NaT'x Catholic Educ. Ass'N BuLc. 228, 229 (1964). See also Gallagher, Observations Arising from the Horace Mann Case, 63 NaT'x CatHolic Educ. Ass'N BULL. 232, 236 (1966): "A flat judgment concerning the morality or sinfulness of a particular practice simply has no place in the history classroom or the science laboratory." Downey, Suppose Parochial Schools Receive Federal Aid . . . , CarHoric ScHoor J., March 1967, at 44, takes the position that parochial schools, "in developing explanations of the hife of Christ ... [should not] step over into anti-Semitism," nor should they in treating "doctrinal differences among Christians, [step] into attack upon the sincerity of Protestants as persons." Id. at 50. Further, he points out that the "pursuit of secular learning should be considered hallowed in itself both because of its origin in the Divine Intellect and because it is imparted in a setting sponsored by the teaching Church. Well-meaning attempts at introducing additional devotion and piety into geography, arithnetic, etc." are unnecessary, id. at 51 . For a similar attitude of Christian Reformed parochial school education, see LaNoue, supra note 207 , at 284.

The recent testimony of supervising administrators of the Catholic school systems in Chicago and Pittsburglı was that a large percentage of the textbooks used in their elementary and secondary schools was also widely used in the public schools. 2 Hearings on H.R. 2361, supra note 35 , at 809,810 .

211 Hearings on H.R. 6074, supra note 202, at 55, 263. In a recent Chicago shared time plan, all courses except English, social studies, music and art were taken in the public school. See Morton v. Board of Educ., 69 Ill. App. 2d 38, 216 N.E.2d 305 (1966). 
of God in these areas" in the parochial school. ${ }^{212}$ Thus, it is concluded, the reason for maintaining a separate parochial school system is not for the purpose of teaching a wholly different curriculum. Rather, it is to add "the most important of the four R's," dren attending public schools that taught only secular subjects five days a week would consider religious training unimportant, and that this impression could not be overcome by a few after school hours or Sunday school. ${ }^{214}$

Several facts emerge clearly from the foregoing discussion. First, "permeation" is a word of varied and imprecise meaning. Father Drinan can state as "the undeniable fact that secular instruction in a Catholic school is 'permeated' by a Catholic atmosphere and Catholic attitudes,"215 yet urge that "permeation should avoid every suggestion of quasi-coercion or 'indoctrination." "218 Second, the secular courses taught in parochial schools rarely, if ever, mirror exactly the courses taught in the public schools. Third, although "no scientific study has ever been done on the extent of the permeation of sectarian teaching in the instruction in secular subjects in Catholic schools,"217 it is likely that some secular subject courses in some parochial schools are so "permeated" that they are in reality courses of sectarian indoctrination, ${ }^{218}$ despite the regulatory power

212 Smith, Symposium, supra note 206, at 10, 11. See also Geoghegan, id. at 24, 25.

2132 Hearings on S. 181 and S. 717 Before the Senate Comm. on Education and Labor, 79th Cong., 1st Sess., at 651 (1945) (testimony of Edward S. Heffron, Executive Secretary, National Council of Catholic Men).

214 See Mitchell, Religion and Federal Aid to Education, 14 Law \& ConteMp. Prod.

$113,132-33$ (1949).

215 R. Drinas, supra note 50, at 229.

216 Drinan, The Challenge to Catholic Educators in the Maryland College Case, NaT'x CatHolic Edvc. Ass'N BuLL., May 1967, at 3, 7. The following interesting definition of the term's objectives reveals its latent ambiguity: "We want religion to permeate the curriculum of our schools, so that our children may have the opportunity to learn how to construct for themselves a world view that is rationally theistic, in contrast to the shattering dichotomy between rehigion and science, between ethic; and business or politics, between the supernatural and the natural, that characterizes the world view of so large a part of society today." Hanlon, Federal Aid?, 110 AMcERICA 418 (1964). That the federal government does not regard "permeated" parochial education as intrinsically a religious activity is evidenced by the fact that tuition contributions to its support are not deductible for income tax purposes as religious contributions. See G. LANouE, supra note 56, at 43.

217 Drinan, The Constitutionality of Public Aid to Parochial Schools, in Tre Warc BetWeen CHURCH AND STATE 55, 64 (D. Oaks ed. 1963).

218 An article by Sister Carolyn, Lay Teachers Have a Spiritual Role, CatHourc Sceoor J., Jan. 1963, at 43, 44, urges that secular course instructors "so teach that the Christian principles become guiding principles. ... Convinced that Christian principles unust be the motivation for acts, you teach differently from a textbook teacher. Your teaching is structured upon principles, the truths of a Christian life. By a gradual buildup of understandings which shape into a generalization, you lead the child to discover truth rather than impose or patch on him a fact of information. . . . All of our units of study are directed to form a person who thinks, judges, and acts like Christ." 
of the state-whether exercised or not; ${ }^{219}$ that some courses are completely, bona fide secular; ${ }^{220}$ that some courses fall between these extremes. Fourth, the problem of the parochial school secular courses being turned into nothing more than religious instruction is not inherent; no religion demands it, nor constitutionally could a religion demand it if contrary to reasonable state requirements. ${ }^{221}$

\section{Extent of Permissible Aid}

Under the rationale proposed in this article, public financial assistance to parochial education may not exceed the value of the secular educational service rendered. One relatively effortless way of avoiding the whole problem of permeation in this connection is simply to ignore it by taking the position that "the secular character of secular subjects is not changed by a moral or religious permeation"; "that it is impossible to study and interpret man and his activities apart from his moral and religious values"; and that "the National Merit Scliolarship competition ... is clear evidence that students who attend church-related schools receive a secular education as good as that received by students in our public schools."222 On this reasoning, there would be no prohibition to financing accredited parochial schools on a lump-sum parity with public scliools without further investigation. ${ }^{223}$

219 See A. Stokes \& L. Pfefrer, supra note 27 , at 413 But see Hayes, supra note 10, at 175 n.33; Kenealy, Equal Justice Under Law-Aid to Education, 11 LoxoLA L. Rev. 183, 198 (1962-63). For discussion of the exercise of state regulatory power over nonpublic schools, see text accompanying notes 472-89 infra.

220 An article by Sister Alice, Modern Art in the Religious Class, Carmoxrc ScHoor J., Jan. 1963, at 46, 48, recommends that "regardless of our feelings toward modern art, we will not impose our likes, dislikes, and prejudices upon our students." An article by Sister Paulinus, Bacteriology in the High School, id, at 49, gives a fully objective account of the technical problems of studying the subject. For similarly written instructional essays by Catholic educators, quite divorced from religious influences, see O'Neill, The Homeroom in the Guidance Program, id. at 60; Sister Ruth, Budding Poets, id, at 67; Phillips, Written Recitation in Teaching Science, id. at 68; Sister Christina Marie, Geometric Forms Taught in First Grade, id., Feb. 1963, at 46; Sister Marion Beiter, Teacher Training for Secondary Mathematics, id. at 50; Sister Marie Josepl, How We Teach Russian, id. at 51; Sister M. Martin, Freshnen Really Read, id. at 54.

221 See discussion in text accompanying notes 477-89 infra. See also Drinan, Does State Aid to Church-Related Colleges Constitute an Establishment of Religion?-Reflections on the Maryland College Cases, 1967 Utä L. Rev. 491, 494, 505; Manning, Aid to EducationFederal Fashion, 29 FordenAM L. REv. 495, 523-24 (1961).

222 Blum, supra note 37 , at 153. See also id. at 140; 2 Hearings, on H.R. 2361, supra note 35, at 819-20 (testimony of Msgr. Frederick G. Hochwalt).

223 Until recently, there has been no comprehensive published study comparing the academic and other achievements of parochial school students to those of public school students. See Jencks, Catholics and Our Schools, New Republic, Mar. 19, 1962, at 21, 22. Sucl a major sociological study, comparing Catholic school Catholics and public school Catholics, entitled The Education ce Catholic Americans, by Andrew M. Greeley, a 
But this may be too simple. Competitive examinations and sociological studies are not so exact as to determine conclusively that the educational services rendered in parochial schools are as complete and effective and have the same impact from a nonreligious perspective on the overall development of the student as does public school education. Viewed from the basis of per-hour input, it is reasonable to assume that this is not the case, given the parochial school time spent on religious instruction. And it is clear that the state may not subsidize religious instruction or indoctrination, no matter where undertaken.

The establishment clause prohibition agamst using tax funds for strictly religious purposes appears to require a more careful scrutiny to

Catholic priest, and Peter H. Rossi, a Protestant, was published in 1966 under the auspices of the National Opinion Research Center.

The monograph lends support to the contention just discussed in text accompanying note 222 supra. Among the controlled findings were that Catholic school Catholics increased their social class margin over other Catholics, $i d$. at 57 ; that those who went to Cathohic primary schools were more likely to graduate from high school than other Cathohics and were just about as likely to do so as public school Protestants, $i d$. at 49-50; that those who went to Catholic high schools were more likely to go to college than Catholics and almost all classes of Protestants who went to public high schools, $i d$. at 50; that Catholic school Catholics scored significantly higher on a brief general knowledge test than did public school Catholics, id. at 120; that Catholic school Catholics ranked measurably higher on an occupational-prestige index than did public school Catholics, id. at 140. The authors conclude that "there is no evidence that Catholic education interferes with occupational or educational achievement." Id. at 146. Relevant thereto is the judgment of Catholic high school Catholics mdicating that their schools are no more "repressive" or "authoritarian" than other schools. "There are no significant differences in the proportions saying they are free to disagrce in class, that all students are treated equally, or that they are free to talk to the teacher if they think they have been treated unfairly. Indeed, in two of the three instances, the slight associations that do exist suggest that Catholic schools may be somewhat more hberal in these matters." Id. at 193.

The survey also revealed interesting results as to attitudes. It found no evidence that Catholic school Catholics were less tolerant of members of other groups, id. at 122; were less likely to defend civil liberties, were more given to extremist religious attitudes or to distrusting world and worldly effort, or were more rigid in their child-rearing practices, $i d$. at 125; that, while Catholic school Catholics do interact less with other Americans while in school, this does not continue in later life, $i d$. at 121. Other studies have shown that differences between Catholic and non-Catholic schooling, in respect to such matters as participation in the community, values concerning occupational achievement, or the political goals of American society, are nonexistent. See J. Ficirter, Parochind Scrools: A Socrorogrcar Study 116 (1958); Rossi \& Rossi, Some Effects of Parochial School Education in America, 90 DaEdaLUS 300 (1961) ; Rossi \& Rossi, Background and Consequences of Parochial School Education, 27 Harv. Eddc. Rev. 195 (1957). See also A. Greetey \& P. Rosst, TreE Education of Cathoitc Americans 8-9 (1966).

Finally, it must be observed that the Catholic school education did produce religious consequences. Catholic school Catholics were more likely to engage in sacramental activity, $i d$. at $56-57,71$, were more "loyal" to the ecclesiastical system, $i d$. at 60 , were better informed on the "fine points" of religious knowledge, id. at 61 , and were more orthodox in their moral beliefs, id. at 63. See also Kelley, Protestants and Parochial Schools, in FEDERAx ATD axd Catmolic Schoors 71, 77 (D. Callahan ed. 1964). 
assure that only the secular aspects of parochial school education will be publicly financed.224 But to admit "an admixture of religious with secular teaching"225 is the beginning, not the end, of the inquiry. To concede that "commingling the religious with the secular teaching does not divest the whole [course or activity] of its religious permeation and emphasis,"220 is not to conclude that no part of the course or activity may be aided with public money.

A secular subject parochial school course or activity may concurrently serve independent, dual purposes-that is, full secular value may be obtained for the time and resources expended, and religious interests may also be served. If such is the case, the entire course or activity serves a primary secular purpose - and may therefore be fully financed-the aid to religion notwithstanding. ${ }^{227}$ On the other hand, a secular subject parochial school course or activity may partially serve both religious and secular ends. Here, an allocation must be made; only the secular product may be publicly financed. ${ }^{228}$ Of course, if a "secular subject" parochial school course or activity is in reality religious instruction, it cannot be publicly funded at all; and if it is exclusively secular in purpose, it may be totally funded.

(a) The Relevance of "Atmosphere."-Before applying this approach, certain other matters should be considered. That the general atmosplere of parochial scliools - as created by religious symbols, teachers in religious attire, and compulsory rehigious exercises and courses-is oriented toward religious goals ${ }^{229}$ should not affect the constitutional judgment

224 It is not an adequate response to say that, since classroom religious neutrality is impossible in interpreting any subject matter, a secularist religion is being tauglit in the public schools; therefore, the fact that a religious orientation is given a parocilial school subject slould not disqualify it from full public support. See Blum, Freedom and Equality, in Federar ATD and Catholtc Schoors 43, $45-47$ (D. Callalıan ed. 1964); cf. note 59 supra (last paragrapl1). Perliaps public schools should avoid any indoctrination in ultimate values, see Kauper, supra note 18, at 23 ; but if a public school teacher illustrates points by calling on universally accepted moral values, derived from classically neutral nonreligious sources, this is not religious indoctrination in the accepted sense. See Choper, supra note 4, at 377-79. That a publicly accepted and espoused behavioral standard is adopted by a religious group (say, the Secular Humanists) as its own moral or ideological tenet, does not make it a "rehigious" tenet for all purposes. Cf. McGowan v. Maryland, 366 U.S. 420, 442, 445 (1961); School Dist. v. Schempp, 374 U.S. 203, 225 (1963). See generally Giannella, supra note 199, at 562-63; Note, 61 Nw. U.I. Rev. 705 (1966). See also note 59 supra (last paragraph).

225 Everson v. Board of Educ., 330 U.S. 1, 47 (1947) (dissenting opinion of Rutledge, J.).

226 Id.

227 See discussion at notes 105, 108, 111, 125-28, 133-38 supra. "The real issue is whether the plilosophy of education professed in any way diminishes the content and methodology of the secular subjects taught at these church-connected institutions." Costanzo, supra note 37, at 649. See also id. at 635. But see Note, 62 Nw. U.L. Rev. 253, 262 (1967). 228 See Note, 22 LA. L. Rev. 266, 269 (1961).

220 See G. LANous, supra note 56, at 32 ; Gordon, The Unconstitutionality of Public Aid 
as to whether the particular course or activity may be publicly funded. The clearly sectarian purpose of these accouterments produces no infringement of religious liberty, since students attend the parochial schools of their own volition. ${ }^{230}$ And since public funds are not used to subsidize these items, but only for the proven secular aspects of the educational experience, no expenditure of tax inoney for religious purposes results. (b) Judicial Definition of "Religion."-Under the analysis proposed herein, the question whether a particular course or activity serves a primary secular purpose, a primary rehgious purpose, or mixed purposes must ultimately be for the Court. It "must be ready to define religion, religious teaching and rehgious commitment."231 But this would not be a novel exercise for the judiciary.

As has already been noted, ${ }^{232}$ the Court has on a number of occasions labeled particular governmental activity religious or secular. In the Sunday Closing Law Cases, the Court expressed its willingness and obligation to engage in "close scrutiny"233 to determine if an action's purpose and "its operative effect" examine challenged parochial school courses and activities when necessary. ${ }^{235}$

In the Regents' Prayer Case, which is closely analogous to the question in issue, the Court passed judgment on such public school activities as recitation of the Declaration of Independence (or the Gettysburg Address) and the singing of the Star Spangled Banner-all of which are somewhat religiously "permeated"-and concluded that these exercises were "patriotic or ceremonal" rather than "religious."238 In the Bible Reading Cases, the Court ruled that study of the Bible and religion "as

to Parochial Schools, in Tye Wart between Church and State 73, 90 (D. Oaks ed. 1963); Slough \& McAnany, supra note 37, at 61-62.

230 See also discussion in text accompanying note 551 infra.

231 Kauper, supra note 142 , at 294.

232 See discussion in text accompanying notes 112-16 stzpra.

233 McGowan v. Maryland, 366 U.S. 420, 449 (1961).

234 Id. at 453. See also Two Guys from Harrison-Allentown, Inc. v. MeGinley, 366 U.S. 582, 592 (1961); Gallagher v. Crown Kosher Market, 366 U.S. 617, 630 (1961). "After all, the labels a State places on its laws [or a parochial school places on its courses and activities] are not binding on us when we are confronted with a constitutional decision. We reach our own conclusion as to the character, effect, and practical operation of the regulation [course, activity] in determining its constitutionality." 366 U.S. at 573 (dissenting opinion of Douglas, J.).

235 Cf., e.g., Sherbert v. Verner, 374 U.S. 398, 39911.1 (1961) (practice was found to be a "basic tenet" of religious creed); Murdock v. Pennsylvania, 319 U.S. 105, 108 (1943) (practice was found to be an "age-old form of missionary evangelism").

${ }^{236}$ Engel v. Vitale, 370 U.S. 421, $435 \mathrm{n} .21$ (1962). Mr. Justice Douglas found the words "under God" in the pledge of allegiance to have a religious purpose. Id. at 440 n.4 (concurring opinion); cf. Mr. Justice Brennan's discussion in School Dist. v. Schempp, 374 U.S. 203, 304 (1963) (concurring opinion). 
part of a secular program of education"237 was proper, thus addressing itself to the very matter under discussion here.

It has been argued that it is extremely difficult to distinguish religious from secular textbooks; ${ }^{238}$ that "the task of separating the secular from the religious in education is one of maguitude, intricacy and delicacy."2239 But just as the Court, if called upon to do so, must determine whether a public school textbook is religiously indoctrinatory, ${ }^{240}$ or whether a public school history course is really religious instruction, it should make the same constitutional judgment in respect to parochial school affairs. ${ }^{241}$ When a public school action is found rehgious the remedy is to enjoin; when a parochial school practice is held religious, to forbid its public subsidization.

The general undesirability of requiring the Court to define what is religious and what is not need not be disputed. But, althougli the Court "can and must avoid passing on the truth of particular religious beliefs,"242 it cannot escape the former task. "This necessity arises out of the constitutional language itself, which sets down rehgion as a subject for special treatment."243 A judicial defimition must be fashioned under the "absolutist" theory, ${ }^{244}$ which bars all aid to "rehigion." It must be determined under Professor Kurland's thesis, ${ }^{245}$ which forbids classifications in terms of "religion."246 And it must be faced under the rationale proposed herein. ${ }^{247}$

237 School Dist. v. Schempp, 374 U.S. 203, 225 (1963). See also the lengthy discussion by Mr. Justice Brennan, id. at 266-78 (concurring opinion).

238 Board of Educ. v. Allen, 20 N.Y.2d 109, 122, 228 N.E.2d 791, 798, 281 N.Y.S.2d 799, 809 (1967) (dissenting opinion), prob. juris. noted, 36 U.S.L.W. 3278 (U.S. Jan. 15, 1968). See also U.S. Dep't of Health, Education \& Welfare, supra note 20, at 358: "[I]t is readily apparent that what one person would classify as simply secular knowledge another would regard as religious instruction." But see Kenealy, suppra note 219, at 204.

230 McCollum v. Board of Educ., 333 U.S. 203, 237 (1948) (concurring opinion of Jackson, J.).

$240 \mathrm{It}$ bas been asserted that, "Many of the public school textbooks present Protestantism in a more favorable light than Catholicism and Christianity more favorably than Judaism .... There are definite sectarian tendencies in the textbooks." Corley, Objections to Aid Answered, in Eddcatronal FreEdour 184, 192-93 (D. McGarry \& L. Ward eds. 1966) (emphasis omitted). See also Pflug, Religion in Missouri Textbooks, 36 PHI DeLta KappaN 258 (1955).

241 The Court has said of its religious "neutrality" rule that its application "requires interpretation of a delicate sort," School Dist. v. Schempp, 374 U.S. 203, 226 (1963).

242 Mansfield, Book Review, 52 CALIF. L. REv. 212, 216 (1964), referring to United States v. Ballard, 322 U.S. 78 (1944).

243 Mansfield, supra note 242 , at 216.

244 See text accompanying notes 346-53 infra.

245 See text accompanying note 58 supra.

240 See generally Mansfield, supra note 242, at 215-16.

247 It would undoubtedly ease judicial administration if parochial school students took all secular courses in public schools as part of a shared time program and then returned to 
As has been the case concerning the Court's handling of the issue of rehigious exercises and activities in public schools, most decisions under the proposed rationale for adjudicating these problems in parochial schools will not be difficult. The Court, guided by common sense and the obvious effects of the activity, ${ }^{248}$ rather than by its own "prepossessions," 249 may set the standard in a few cases. If abuses occur, they may be checked by federal or state aid administrators, ${ }^{250}$ reviewed by state and lower federal courts, with ultimate review always available in the Supreme Court. ${ }^{251}$

Pragmatically, the issue should rarely arise, at least in the foreseeable future, for it is highly unlikely, as a matter of political reality, that the total amount of governmental assistance to parochial education will even approach the conceded value of the secular educational services it renders.

(c) Illustrations. - Keeping this last point in mind, some specific illustrations of problems that could arise under the proposed rationale may be helpful. The second grade arithmetic text assigned in a Catholic parochial school may use sectarian characters, illustrations or examples, phrasing arithmetic problems in terms of rosary beads instead of apples, ${ }^{262}$ and using pictures of parochial scliools instead of public schools. Or, if the text is "clean," the teacher may use these illustrations. Trumpet instruction may involve an unusual amount of religiously-oriented music, and French language instruction may include a high concentration of religously-significant words or reading. ${ }^{253}$

the parochial school for the requisite "permeation" and other religious instruction. See G. LANouE, supra note 56, at 44. But, when essentially the same secular public school course may be offered in the parochial school, there is little justification for elevating a rule of administrative convenience into a constitutional mandate. And see text following note 251 infra.

248 See text accompanying note 122 supra.

$249 \mathrm{McC}$ Collum v. Board of Educ., 333 U.S. 203, 238 (1948) (concurring opinion of Jackson, J.).

$250 \mathrm{Mr}$. LaNoue suggests that a major flaw in granting aid to parochial schools would be that "an authority would lave to be set up to supervise local curricula, to censor textbooks for religious material and to investigate infractions and abuses with public money." LaNoue, supra note 207, at 291. In respect to the rationale proposed berein, this is an overstatenient. Perhaps such a public agency should be set up, irrespective of public financing, as it already is for public schools, to assure that parochial schools offer a sound educational program. See text accompanying notes $472-75$ infra. If public aid is given, lowever, the only necessary desideratum (although not, of course, constitutionally required) is to constitute an official to check abuses.

251 See McCollum v. Board of Educ., 333 U.S. 203, 238 (1948) (dissenting opinion of Reed, J.).

252 See 107 AMERICA 1201 (1962). See also J. FICHTER, supra note 223, at 86; LaNoue, supra note 207, at 272-73, 275.

253 See LaNoue, supra note 207, at 276. See also McGowan v. Maryland, 366 U.S. 420, 445 (1961) (statutes use religiously oriented terms). 
Considerations of religious liberty, not present in voluntarily-attended parochial schools, might prevent all or some of this in public schools. ${ }^{254}$ But in the examples above, full secular value seems to have been obtained for the time and resources expended, despite the fact that religious interests may also have been served..$^{255}$

(1) Burden of Justification.-Some educators might urge that the above uses of sectarian material did not afford the parochial pupils a secular educational experience completely analogous to that offered in the public schools. If sucli a case is made, the state or federal financing agency and the recipient paroclial school should have the burden of justifying allocation of the full cost of the course to the secular side of the ledger. Although legislative and executive action ordinarily carries a much stronger presumption of constitutionality, ${ }^{256}$ the Court has forcefully held that this is not the case when the precious personal freedoms of speecl, press, and religion are at stake. ${ }^{257}$

It may seem to some that individual liberty is only indirectly affected when governmental grants to religious bodies are challenged under the establishment clause, ${ }^{258}$ thus vindicating use of the usual presumption of constitutionality or something close to it. But the prohibition against the use of compulsorily raised tax funds for strictly religious purposes, central to the concept of nonestablishment as an important guarantor of religious liberty, suggests that here, too, the regular presumption should be modified. ${ }^{259}$ Thus, after an opponent of aid initially demonstrates that a parochial school course or activity is in whole or part primarily religious, in the sense used in this article, the obligation of rebuttal should rest with those defending aid. In cases of uncertainty, the issue should be resolved against the public funding. ${ }^{260}$

${ }^{254}$ Cf. Dickman v. School Dist., 232 Ore. 238, 243, 366 P.2d 533, 536 (1961), cert. denied, 371 U.S. 823 (1962).

255 But see S. Hoor, supra note 59, at 111 . The constitutional effect would seem to be little different than if a parochial school mathematics, music, or language teacher is trained at public expense, see 20 U.S.C. $\$ 425$ (b) (3) (1964); id. § 1111 (Supp. I, 1965), and then uses the techniques discussed in teaching his parochial school class.

250 Metropolitan Cas. Ins. Co. v. Brownell, 294 U.S. 580, 584 (1935), and cases there cited.

257 Cases cited by Justice Frankfurter in his concurring opinion in Kovacs v. Cooper, 336 U.S. 77, 90-96 (1949).

258 See Comment, 13 U.CL.A.L. Rev. 1100, 1113-14 (1966).

259 See Comment, 21 S. CAL. L. Rev. 61, 67 (1947); of. Sullivan, Religious Education in the Schools, 14 LAw \& Contearp. Prob. 92, 107 (1949). But see Reed, The "Permeation" Issue in Federal Aid to Education, 8 Catrolic Law. 197, 201 (1962).

200 Butt cf. Mitchell v. Consolidated School Dist., 17 Wash. 2d 61, 75, 78, 80, 135 P.2d 79, 85, 86, 87 (1943) (dissenting opinions); State ex rel. Reynolds v. Nusbaum, 17 Wis. 2d 148, 171-72, 11 N.W.2d 761, 773 (1962) (dissenting opinion). 
(2) Examples.--In a parochial school biology text or course, after a full explanation of the theory of evolution, the church's perspective on the matter may also be fully articulated. ${ }^{201}$ Or, in the civics course, the concept of racial equal protection may be amplified by presenting both the relevant secular and theological values. Since there would seem to be no constitutional objection to such an objective presentation in the public schools, ${ }^{262}$ there should likewise be none liere, despite the concurrent religious educational value, and despite the fact that these matters may never be mentioned in the average public school class. ${ }^{263}$ They still have significant secular educational value. ${ }^{264}$ Even a parochial school course in "religion" itself may so qualify if properly handled. ${ }^{205}$

There is a very fine line, however, between objective presentation and subtle commitment, ${ }^{266}$ and this truth is not confined to parochial schools. Some texts used in public schools ${ }^{267}$-and, undoubtedly, some teachersunintentionally emphasize Humanistic or: antireligious values. ${ }^{268} \mathrm{Un}$ doubtedly, the opposite is also true. Such emphasis will vary from public school to public school, dependent in part on the cultural, religious and racial composition of the students and teachers. ${ }^{260}$ To the extent that this is constitutionally permissible, effectively unavoidable, or de minimis in the public schools, it slould be similarly unobjectionable in the parochial schools for the purpose of public funding-subject always to the burden of justification discussed above. ${ }^{270}$

\footnotetext{
261 See LaNoue, supra note 207 , at 465.

262 Cf. McCollum v. Board of Educ., 333 U.S. 203, 235-36 (1948) (concurring opinion of Jackson, J.).

263 Smith, Catholic Science Textbooks?, 110 AMERrCA 78 (1964), suggests that some public school textbooks in the natural sciences (that are also used in some parochial schools) fail to mention any relevant religious views. See also the view of Mr. Justice Brennan that "to what extent, and at what points in the curriculum, religious materials should be cited are matters which the courts ought to entrust very largely to the experienced officials who superintend our Nation's public schools." School Dist. v. Scliempp, 374 U.S. 203, 300 (1963) (concurring opinion).

264 See Recd, supra note 259 , at 197 . Even if virtually every parochial school course contains an objective presentation of the religious viewpoint, see LaNoue, supra note 207 , at 290, it might well pass muster so long as it is not done to the detriment of a rensonably well rounded secular education. Separate courses on "the lives of the Saints," see Catrocic ScHOOI J., Feb. 1963, at 24 (advertisement), or "the cvils of Conımunism," sec id., Jan. 1963 , at 22 (advertisement), would present this problem. The defense burden of justification is here relevant. See discussion in text accompanying notes 256-60 supra.

265 See McQuilken, Religious Instruction, 86 CoMmonweAI 48 (1967).

286 "It is too much to expect that mortals will teach subjects about which their contemporaries lave passionate controversies with the detachment they may summon to tcaching about remote subjects . ..." McCollum v. Board of Educ., 333 U.S. 203, 236 (1948) (concurring opinion of Jackson, J.).

267 These are sometimes also used in parochial schools. Smith, supra note 263.

288 Id.

269 See McCollum v. Board of Educ., 333 U.S. 203, 237 (1948) (concurring opinion of Jackson, J.).

270 See discussion in text accompanying notes 256-60 supra.
} 
A parochial school history course or text may teach that all major events are related to or produced by one of the basic truths of the religion, ${ }^{271}$ or may emphasize the contribution of one religion over all others. ${ }^{272}$ Parochial school texts in English composition may "stress Catholic religious words and teachings," ${ }^{273}$ or a current events class may use a weekly magazine whose articles are "Catholic-oriented." An advanced biology text or course may omit all references to birth control, sterilization, and euthanasia, ${ }^{275}$ or specifically reject most parts of evolutionary theory and shift scientific concepts so that they appear to be based on religious tenets. ${ }^{276} \mathrm{~A}$ parochial school geography text may describe only Cathohic families in various cultures, ${ }^{277}$ or the teacher may ask the students to map all Cathohic churches in the state of Nebraska. ${ }^{278}$

Clearly, some $e^{279}$ or all of these parochial school activities, as well as some referred to earlier, ${ }^{280}$ cannot be fully supported with public funds. Either the quantity of religious perspective has deprived the course of full secular educational value, or the quality of sectarian permeation has so slanted the material as to liave partially undermined or even fully destroyed its secular content. The very description of these courses and texts appears to state a sufficient case to shift the burden of justifying any quantum of secular value to those defending governmental support.

\section{E. Allocation}

It must be reemphasized that, as a realistic matter, problems of the nature just discussed will arise rarely, ${ }^{281}$ as will problems of allocating cost between rehious and secular parts of "mixed" parochial school activity. As with the issue of permeation, the burden of justifying both the propriety of the allocation and the method used should be on the government or recipient defendant once the assailant has made the requisite initial demonstration.

Several problems of allocation that have disturbed courts may serve as brief illustrations. The cost of bus transportation to parochial schools, for example, cannot be allocated in "proportional shares as between the

271 See Albert, Teaching History in the Elementary School, 51 Catrolic ScHoox J. 10 (1951).

272 See A. Stokes \& L. Pferfer, supra note 27, at 411.

273 See CATHOLIC Schoor J., Jan. 1963, at 86 (advertisement).

274 See id. at 88.

275 See LaNoue, supra note 207 , at 265.

270 See id. at 284.

277 See id. at 271.

278 Sister Julian, Does Johnny Like Geography?, Carmorac Schoor J., Jan. 1963, at 66. 279 The most obviously suspect are those discussed in text accompanying notes 271,272 , 274,276 , and 277 supro.

280 See text accompanying notes 207,218 supra.

281 See text following note 251 supra. But see G. LANoov, supra note 56, at 32. 
secular and religious instruction."282 The reason is that, as will be amply shown, ${ }^{283}$ the activity fully serves an independent secular purpose. Thus, its value, if provided by the parochial school while public school children are bussed at public expense, may be completely listed in the secular services column. No allocation is necessary.

Suppose that public funds are used to construct a building for educational research on the campus of a cliurch-affiliated college, title being vested in the school. ${ }^{284}$ If the building is always used for this purpose as contemplated, no allocation problem arises. But suppose, after three years, the building is to be converted into a chapel and utilized exclusively for rehgious purposes. If in the building's three years as a research center, the total governmental contribution to the college, including the full amount of the grant for the building, did not exceed the value of the secular educational service rendered by the college, the matter is closed. The fact that the building will now be used for religious purposes is irrelevant. The taxpayers have gotten at least full secular value for their contribution. But, if in those three years the total governmental contribution, including the grant, exceeded the value of the college's secular educational services, the building may not be used for religious purposes until the college reimburses the government for the excess amount or some other proper arrangement is made. The science of accounting, with judicial review when appropriate, is neither above nor below the needed task.

\section{F. Relevant Supreme Court Decisions}

Reference has previously been made to passing remarks by some observers suggesting that existing Supreme Court opinions have already resolved the problem of aid in parochial schools. ${ }^{285}$ It is Everson v. Board of Education ${ }^{286}$ that is most frequently cited for this proposition-by advocates on both sides of the issue. The brief of the National Catholic Welfare Conference reasons: "The underlying principle of the case is plain: government aid may be rendered to a citizen in furtherance of his obtaining education in a church-related school."2887 It points out that the majority opinion's stringent interpretation of the establishment clause, ${ }^{288}$ although more than a mere dictum, "must be read in the light of the

\footnotetext{
282 Everson v. Board of Educ., 330 U.S. 1, 46 (1947) (dissenting opinion of Rutledge, J.).

283 See note 510 infra.

284 Horace Mann League v. Board of Pub. Works, 242 Md. 645, 683, 220 A.2d 51, 72, cert. denied, 385 U.S. 97 (1966).

285 See text accompanying notes 9, 143 supra.

286330 U.S. 1 (1947).

287 National Catholic Welfare Conference, supra note 37, at 417.

288 The language is set forth in text accompanying note 8 supra.
} 
actual result of the case .... [which is that] secular education in church-related schools . . . is supportable by government," 289 and in hight of the opinion's edict that the state "cannot exclude ... [persons], because of their faith, or lack of it, from receiving the benefits of public welfare legislation"; ${ }^{290}$ that there was "careful avoidance by the majority of any rule which would preclude aid [for] . . . secular subject training." "291 Finally, it reads the Court's language barring any tax support for "any rehgious activities or imstitutions, whatever they may be called, or whatever form they may adopt to teach or practice religion," only excluding "aid in support of (a) the teacling or practicing of religion ... ; (b) religious institutions as religious institutions."293

The argument is incisive and not unpersuasive. But it is by no means conclusive. An argument at least as convincing can be made the other way: The whole tone of the majority opmion ${ }^{294}$ strongly implied that bus transportation narked the outermost limit of permissible governmental aid. The Court suggested that the plan at bar went to the "verge"295 of the state's constitutional power. The Court said, albeit in dictum, that the establishment clause forbade a state to "contribute taxraised funds to the support of an institution which teaches the tenets and faith of any church"; ${ }^{296}$ that the line to be drawn is "between tax legislation which provides funds for the welfare of the general public and that which is designed to support institutions which teach rehgion."297 The latter point seems directly to contradict the "religious institutions as religious institutions"298 conclusion. In the bussing situation presented

280 National Catholic Welfare Conference, supra note 37, at 418. Mr. Pfeffer concedes that the result leads logically to that conclusion. L. Pferfer, supra note 26, at 568.

200330 U.S. at 16.

291 National Catholic Welfare Conference, supra note 37 , at 420.

202 See note 8 supra and accompanying text.

203 National Catholic Welfare Conference, supra note 37, at 420-21. See also Costanzo, supra note 37, at 620-26; Drinan, The Constitutionality of Public Aid to Parochial Schools, in The Watr between Church and State 55, 66 (D. Oaks ed. 1963). Contra, Aurerican Jewish Congress, Schools, Subsmies and Separation 3 (1965); 5 Hearings on S. 370, supra note 148, at 2750 (Statement of Dr. C. Stanley Lowell, Associate Director, Protestants and Other Americans United for Separation of Cluurch and State). See also W. KATz, supra note 48, at 70-71: "This sentence [in Everson] is certainly not free from ambiguity. The question is whether the thrust is against support of religious teaching or, more broadly, against any support of institutions which give such teaching. The latter interpretation is perhaps more easily justified as a matter of grammar." See also R. DrRnar, supra note 50, at 131-33; Davidow, supra note 131, at 678.

294 See Jones, Church-State Relations: Our Constitutional Heritage, in Retigron AND CONTEMIPORARY SOCIETY 156, 194 (H. Stahmer ed. 1963); Gordon, supra note 229, at 85; Pfeffer, in Dorsen, supra note 33, at 38-39.

295330 U.S. at 16.

290 Id.

297 See id. at 14.

298 See text accompanying note 293 supra. 
by Everson the Court stressed that the state "contributes no money to the schools,"299 and that the services provided were "indisputably marked off from the religious function"300 of parochial schools.

In respect to the proposal advanced in this article for aid to parochial schools, the best that can be said of the Everson opinion ${ }^{301}$ is that all discussion by the majority beyond that vital to the result of the case itself was dictum and that discussion in subsequent Supreme Court opinions ${ }^{802}$ lends some credence to the proposal urged herein.

Advocates on both sides of the issue also rely on Bradfield $v$. Roberts, ${ }^{303}$ which held that federal appropriations for ward construction and care of indigent patients to a hospital in the District of Columbia operated by the Roman Catholic Church did not violate the establishment clause. The National Catholic Welfare Conference contends that the Court recognized that "the church exercises great and perhaps controlling influence over the management of the hospital." ${ }^{1304}$ Thus, it concludes that the Court "did not rule that a direct appropriation to a sectarian institution would be unconstitutional." therefore that Bradfield and Everson are "clear precedent for aid."

The language relied on in Bradfield, however, may represent not the Court's conclusion, but its statenient of the complainant's allegation. For the Court carefully explained that the hospital, incorporated by act of Congress, was simply "a secular corporation being managed by people who hold to the doctrines of the Roman Catholic Church, but who nevertheless are managing the corporation according to the law under which it exists"; ${ }^{307}$ and that its "property and its business are to be managed in its own way, subject to no visitation, supervision or control by any ecclesiastical authority whatever, but only to that of the Government which created it." ${ }^{2308}$ This surely may not be said of parochial scliools. But neither may it be said, as opponents of aid allege, that "[i]mplicit in this decision is the holding that the Constitution would be violated by a

299330 U.S. at 18. See also Opinion of the Justices, 233 A.2d 832, 835-36 (N.H. 1967). 300330 U.S. at 18. For specific reliance on this point, see Rhoades v. School Dist., 424 Pa. 202, 233, 226 A.2d 53, 70 (concurring opinion of Roberts, J.), appeal dismissed, 389 U.S. 11 (1967).

301 That one member of the five man majority has recently indicated a change of view, see Engel v. Vitale, 370 U.S. 421, 443 (1962) (concurring opinion of Douglas, J.), is of little relevance since only he and Mr. Justice Black presently remain on the Court.

302 See text accompanying notes $137-42$ supra.

303175 U.S. 291 (1899).

301 Id. at 298.

305 National Catholic Welfare Conference, supra note 37, at 416.

$308 I d$, at 422.

807175 U.S. at 298-99.

$808 \mathrm{Id}$. at 299. 
grant of Federal money ... to an institution controlled by a sectarian organization"

A more reasonable conclusion is that Bradfield leaves open the aid to parochial schools question. ${ }^{311}$

A number of writers consider Supreme Court decisions involving religion in the public schools as bearing directly on the question of aid to parochial schools. It is true that McCollum v. Board of Educationin which the Court invalidated "on-premises" released time-does refer disapprovingly to "the use of tax-supported property for religious instruction." ${ }^{\prime 312}$ But the entire opinion makes clear that it was an additional factor, the "utilization of the tax-established and tax-supported public school system to aid religious groups to spread their faith,"313 that was conclusive. ${ }^{314}$

Zorach v. Clauson - in which the Court refused to invalidate the New York "off-premises" released time plan-does contain the dictum that "[g]overnment may not finance religious groups ...."315 But it is inaccurate to contend that the Zorach Court distinguished $\mathrm{McC}$ Collum on the ground that "public . . . funds were not used in New York." Rather, the Court stressed that in McCollum "the force of the public scliool was used to promote [religious] instruction," 317 whereas the Court found this not to be so in New York. ${ }^{318}$

Under the rationale proposed in this article the cases dealing with religion in the public schools are clearly distinct from the question of

B09 I. PFefrer, supra note 26, at 534 .

$810 \mathrm{G}$. LANouE, supra note 56 , at 16.

811 The case of Quick Bear v. Leupp, 210 U.S. 50 (1908), is also advanced to support the position that aid to parochial schools violates the establishment clause. The case held that the federal government could disburse treaty funds, held in trust for Indians and legally belonging to them, to church-affiliated schools designated by the Indians to pay tuition costs. The opinion provides no support for the assertion by Mr. Justice Rutledge, in Everson v. Board of Educ., 330 U.S. at 43 n.35, that "it was stated also that such a use of public [rather than tribal] moneys would violate ... the First Amendment" nor does careful reading of the Court's language relied on by Mr. Pfeffer, supra note 26, at 535 .

312333 U.S. 203, 209 (1948).

$818 \mathrm{Id}$. at 210 (emphasis added).

814 See also id. at $209-10,212$. The author of the $M c$ Collum opinion thouglit that he lad made "categorically clear [that] the $M c$ Collum decision would have been the same if the religious classes bad not been held in the school buildings." Zorach v. Clauson, 343 U.S. 306, 316 (1952) (dissenting opinion of Black, J.).

315343 U.S. 306,314 (1952). Two authors cite this statement as indicative of the Court's attitude with regard to the invalidity of aid to parochial schools. G. LANouE, supra note 56 , at 23 ; L. PFerFer, supra note 26 , at 535 .

$816 \mathrm{G}$. LaNour, supra note 56 , at 23 ; see L. PFefrer, supra note 26 , at 535 .

817343 U.S. at 315 .

818 This "deeper difference" has recently been emphasized by Mr. Justice Brennan, concurring in School Dist. v. Schempp, 374 U.S. 203, 262 (1963). See also id. at 223 (opinion of the Court by Clark, J.). 
aid to parochial schools. ${ }^{319}$ That the former involve governmental programs lacking independent primary secular purpose has been documented elsewhere. ${ }^{320}$ That at least certain amounts of governmental financial aid for parochial education serves a primary secular purpose has been documented above. ${ }^{321}$ Moreover, religion in the public schools involves infringements of religious liberty by compromising students' conscientious beliefs. $^{322}$ Although aid to parochial schools involves the expenditure of public money, it has been noted above ${ }^{323}$ that use of tax funds for secular purposes does not violate the constitutionally protected right of conscience. ${ }^{324}$

\section{G. The Doctrine of Alternative Means}

Several members of the Court have employed an "alternative means" rationale in establishment clause cases. ${ }^{325} \mathrm{Mr}$. Justice Frankfurter has theorized that "[i]f a statute furthers both secular and religious ends by means unnecessary to the effectuation of the secular ends alone .... the statute cannot stand." "326 Mr. Justice Bremnan has opined that "[t]he Constitution enjoins those involvements of rehigious with secular institutions which ... use essentially religious means to serve governmental ends where secular means would suffice."

Using this doctrine, opponents of aid for parochial schools have urged its unconstitutionality. They reason that the state's secular goal of maintaining and improving the quality of education for all students may be

319 Thus, the fact that the Court has invalidated public school prayer and Bible reading, Engel v. Vitale, 370 U.S. 421 (1962); School Dist. v. Schempp, 374 U.S. 203 (1963), does not render it "most unconvincing to argue that the Court will turn around and permit the government to subsidize" parochial schools. G. LANouE, supra note 56, at 23.

320 Choper, supra note 4 , at $335,368-77,387-400$.

321 See text accompanying notes $145-49,200-80$ supra. For this distinction see Korbel, supra note 199, at 1021; Sky, supra note 42 , at 1465.

322 For a fuller discussion of this problem, see Choper, supra note 4 , at 368-77, 387-400.

323 See text accompanying notes $155-56$ supra.

324 This reconciles the difficulty of some who find the expenditure of any public funds in aid of parochial education a inuch wider breacls of the "wall of separation" than the on-premises released time condemned in $M c$ Collum or the distribution of Bibles invahidated in Tudor v. Board of Educ., 14 N.J. 31, 100 A.2d 857 (1953), cert. denied, 348 U.S. 816 (1954). See G. Spicer, The Supreme Court and Fundailental Freedoms 82 (1959); Bryson, Mending the Breach, 65 Cerristiar Century 649, 650 (1948). See also Choper, supra note 4, at 361-62.

Since public schools are available to all and are wholly financed by public funds, granting some public aid to parochial schools will not produce "pressures to conform-i.e., to affiliate with some groups which are aided." Davidow, supra note 131, at 687 . See also text accompanying notes 375-77 infra.

325 See generally Wormuth \& Mirkin, The Doctrine of the Reasonable Alternative, 9 UTAF L. REv. 254 (1964).

326 McGowan v. Maryland, 366 U.S. 420, 460-67 (1961) (concurring opinion).

327 School Dist, v. Schempp, 374 U.S. 203, 231 i1963) (concurring opinion). 
achieved without extending governmental financial assistance to parochial schools-that is, without the use of what they characterize as essentially rehigious means. They recognize that the state is constitutionally forbidden to require all students to attend public schools. ${ }^{328}$ But they conclude that the state need only channel aid to the public schools, thus improving their quality, and concomitantly raise the standards of accreditation for private and parochial schools to a similar level. ${ }^{329}$

There are several points to be made in response. First, a majority of the Court has never employed the "alternative means" rationale in an establishment clause case. ${ }^{330}$ Second, a close readimg of Mr. Justice Frankfurter's reasoning indicates that he was only suggesting the doctrme's use when a statute's primary effect was religious and the purported secular end was derivative, ${ }^{331}$ as I have used these terms herein. Third, in respect to government programs that directly serve independent secular ends, Mr. Justice Brennan stresses utilization of the doctrine when the program jeopardizes "the religious liberties of any members of the community."

If a statute's primary purpose is religious, and it presents no real danger to individual religious and conscientious beliefs, perhaps it should be invalid if nonreligious alternative means are available. ${ }^{333}$ And, if a

328 Pierce v. Society of Sisters, 268 U.S. 510 (1925) ; cf. Truitt v. Board of Public Works, 243 Md. 375, 410, 221 A.2d 370, 391 (1966). But cf. U.S. Dep't of Health, Education \& Welfare, supra note 20 , at 379 .

328 See L. PFEFFER, supra note 26 , at 569.

${ }^{830}$ See McGowan v. Maryland, 366 U.S. 420, 450 (1961) in which the Court replied to the argument that it should be used, "However relevant this argument may be, we beheve that the factual basis on which it rests is not supportable." $C$ f. School Dist. v. Schempp, 374 U.S. 203, 224 (1963). Professor Van Alstyne has poimted out that "application of the 'alternative means' idea might well have produced a different result in the Everson case, itself," supra note 68 , at 879 .

331 His principal illustration concerned the use of a religion as an engine of civil policy: "A State may not endow a church although that church might inculcate in its parishioners moral concepts deemed to make them better citizens, hecause the very raison d'être of a church, as opposed to any other school of civilly serviceable morals, is the predication of rehigious doctrine." 366 U.S. at 467 . Further, he acknowledged that "the State may guard its people's safety by extending fire and police protection to the churches," id. In this instance, where there was an independent primary secular purpose-guarding safety-and an equally necessary and inevitable aid to religion, the Justice would not require the use of an alternative means-demanding that eliurches obtain private pohice and fire protection. Finally, he concludes his discussion of "alternative means" with the statement that the "'establishment' contention can prevail only if the absence of any substantial legislative purpose other than a religious one is made to appear." Id. at 468 . Thus, he would find that if there is a legitimate, independent primary secular purpose, the statute is immune from establishment attack despite the existence of alternative means.

332374 U.S. at 281 . He also applies his rationale to action whose primary effect is religious, that is, action that uses religion as an engine of civil policy-and which endangers religious liberty. See his discussion of Torcaso v. Watkins, 367 U.S. 488 (1961), in this context, 374 U.S. at 265.

${ }^{333}$ But see note 51 supra; text following note 83 supra. 
statute's primary purpose is secular, and it presents threats to religious freedom, a persuasive argument may be made that the alternative means doctrine should be employed. ${ }^{33}$ But if a statute's primary purpose is rehgious, and it is likely to result in compromising the individual's religious or conscientious beliefs, as I have argued here ${ }^{885}$ and elsewhere, ${ }^{830}$ it should violate the establishment clause even in the absence of an alternative means. And, finally, if a statute's primary purpose is secular, and it does not impinge on rights of conscience, I would suggest that the alternative means doctrine should not apply even though the statute inevitably affords some aid to religion. Such a statute presents none of the evils at the core of the establishment: ban, and to subject all such legislation to judicial review, for a search for alternative means that afford no aid whatever to religion, would bring innumerable measures before the Court and unnecessarily involve it in an essentially legislative task. ${ }^{837}$ Governmental aid to support the secular aspects of parochial education falls into this final category.

Even if the alternative means rationale were applicable to this final category, it is not clear that aid to parochial schools would be imvahd. Mr. Justice Brennan apparently did not exclude this final category discussed above from the doctrine's coverage, ${ }^{388}$ but he did state that the means used would be invalid only if the secular objectives of the state could be "effectively achieved in modern society" by the alternative nonrehigious means. So, too, Mr. Justice Frankfurter would have applied his thesis only "where the same secular ends could equally be attained by means which do not have consequences for promotion of rehigion."310 Similarly, commentators speak in terms of "practical alternatives less likely to offend the first amendinent," and achievement of the public purpose "by nonsectarian methods without unreasonably mcreasing costs or administrative burdens." 341

A forceful argument may be made that it would be highly ineffective

384 See Choper, supra note 4, at 370 n.240, 383; Moore, The Supreme Court and the Relationship Between the "Establishment" and "Free Exercise" Claulses, 42 Texas L. Rev. 142, 188 (1963).

335 See text accompanying note 53 supra.

386 Choper, supra note 4, at 332-34, 348-50.

337 Cf. Southern Pac. Co. v. Arizona, 325 U.S. 761, 794 (1945) (dissenting opinion of Black, J.). For example, challenge to the constitutionality of fire protection for church buildings could be made on this basis, see note 331 supra.

338 He treated the establishment clause objection to Sunday closing laws which conceded "secular purpose"-and did not compreliend a violation of religious liberty claim (which was made by Sabbatarians under the free exercise clause, see Braunfeld v. Brown, 366 U.S. 599 (1961)) -as being subject to the "alternatives" rationale. 374 U.S. at 265.

330374 U.S. at 265 (empbasis added). See also id. at 281.

340366 U.S. at 467 (emphasis added).

841 Comment, 13 U.C.L.A.L. REv. 1100, 1109 (1966) (emphasis added). See also Truitt v. Board of Pub. Works, 243 Md. 375, 221 A.2d 370 (1966). 
and impractical to aid only public schools and simultaneously raise the accreditation standards for all others. ${ }^{342}$ Apart from the limits that the free exercise clause might place on the state's ability so to regulate parochial schools, ${ }^{343}$ such action could well result in a large influx of private and parochial school students to the public schools. Tax funds would have to be used for construction of expanded public school facilities, and an inefficient and uneconomic waste of existing parochial school facilities would result. . $^{34}$ "Such pragmatic considerations would be irrelevant if the command of the Constitution were clear ... [but] the lack of an effective alternative should be highly relevant when a plausible constitutional defense can be made ...."345

To summarize briefly, the establishment clause should be held to prohibit nonsecular government action that infringes religious belief, and to forbid taxing for strictly rehigious purposes. Therefore, as applied to questions of parochial school aid, the establishment clause should not be held to prevent government from subsidizing these schools to the extent that they provide secular services. As long as the government gets its money's worth of things secular, it should make no difference that the supplying institution is somehow religious in nature. The estabhshment clause, rather than asking whether religious institutions inevitably benefit thereby, should instead ask whether the government is receiving the full value of secnlar services purchased. The question, consequently, is not whether to aid parochial schools which supply secular services, but rather how much aid to extend. In resolving that inquiry, the courts must first characterize an educational service or activity as generally rehgious or secular. If secular, the government nay subsidize it at full value; if rehgious, those defending the aid should carry the burden of showing that the activity contains specific secular aspects entitled to aid. In conclusion, however, it must be remembered as a political reality that the necessity for such allocation will generally remain academic as long as parochial schools continue to provide considerably more in secular services than they receive in aid.

\section{$\mathrm{V}$ \\ OTHER THEORIES}

Earher discussion has traced the operation of a proposed rule for testing the constitutionality under the estabhshment clause of aid to

342 On the question of whether the state may obtain its educational objectives by merely aiding public schools and doing nothing in respect to parochial schools, compare Van Alstyne, supra note 68, at 878, with Kauper, Religion, Higher Education and the Constitution, 19 ALA. L. REV. 275, 288 (1967).

${ }^{343}$ See discussion at notes 479-89 infra. See also Sky, supra note 42, at 1448-49.

344 Note, 41 N.Y.U.L. Rev. 983, 987 (1966).

34577 HaRv. L. Rev. 1353, 1358 (1964). 
parochial schools. Reference will now be made to other theories involving aid to parochial schools and the establishment clause, with particular examination of their own internal consistency and viability and with the intention of further illuminating certain aspects of the constitutional proposals made in this article.

\section{A. Absolutism}

The so-called "absolutist" theory, mentioned earlier, ${ }^{340}$ would prohibit all aid which benefits rehgious institutions either directly or indirectly, ${ }^{347}$ sustaining "appropriations only when it can be found that in fact they do not aid, promote, encourage or sustain religious teaching or observances, be the amount large or small."348 This view "assumes both that state and religion coexist in mutually exclusive and self-contained spheres and that each sphere can be sliarply defined. ${ }^{2849}$ It would seemingly invalidate use of public hibrary books for reading assigned by a parochial school teacher, ${ }^{850}$ the stationing of policemen near parochial schools, fire protection and other municipal services for parochial schools, ${ }^{351}$ and the laying of sidewalks at public expense in front of parochial schools. All these pubhicly funded activities niay fairly be said directly or indirectly to benefit parochial schools and aid, promote and encourage the religious teaching that takes place therein. ${ }^{352}$ It nuay accurately be concluded that the absolutist theory is "of such far-reaching consequence, and in conflict with so many practices, that it is neither administratively, politically, nor ethically [nor constitutionally] tenable." ${ }^{353}$

\footnotetext{
346 See text accompanying note 57 supra.

347 See Greenawalt, in Dorsen, supra note 33, at 44.

348 Everson v. Board of Educ., 330 U.S. 1, 53 (194\%) (dissenting opinion of Rutledge, J.). 34077 HaRv. L. REv. 1353, 1357 (1964).

350 Cf. Linde, Constitutional Rights in the Public Sector: Justice Douglas on Liberty in the Welfare State, 40 WASII. L. REv. 10, 28 n.239 (1965).

351 It does not do to distinguish these as "Inatters of common right, part of the general need for safety. Certainly the fire departanent unust not stand idly by while the church burns." Everson v. Board of Educ., 330 U.S. 1, 60-61 (1947) (dissenting opinion of Rutledge, J.). Secular education is as much a matter of common right, part of the general need for an intelligent citizenry. Certainly the state must not stand idly by while children are inadequately educated.

Nor does it do to say that "education which includes religious training and teaching" has been made a matter "of private right and function" by the free exercise clause, see Pierce v. Society of Sisters, 268 U.S. 510 (1925), and that the use of public funds to defray its cost, therefore, cannot be said to be "for a public purpose." Everson v. Board of Educ., 330 U.S. 1, 51 (1947) (dissenting opinion of Rutledge, J.). Eating fish on Friday may also have been a matter of private right protected by the free exercise clause. But government distribution for health purposes (a primary secular purpose) would not have been barred by the establishment clause.

352 See National Catholic Welfare Conference, supra note 37, at 455; Comment, $A$ Constitutional Analysis of the Wisconsin Bus Law, 1962 Wus. L. REv. 500, 516.

${ }^{353}$ LaNoue, supre note 60 , at 79.
} 


\section{B. Child Benefit v. Aid to School Itself}

The so-called "child-benefit theory"354 also fails in its purpose of both presenting a viable constitutional test and confining the amount of permissible public aid for parochial education. This approach takes several forms. Principally, the theory distinguishes between valid public assistance to aid the child and invalid public assistance to aid the parochial school itself. Under it, "lunches, textbooks, bus transportation, and health services" are "clearly constitutional"; 355 appropriations for "language instruction and laboratory facilities" ing, maintenance and teachers' salaries are foreclosed."

Although this theory may be characterized as "a workable compromise interpretation of the First Amendment," ${ }^{368}$ it places form over substance. The hard fact is that aid for any secular educational purpose, from transportation and textbooks to construction of a science laboratory and payment of a Spanish teacher's salary, helps the child to take his proper place in society. ${ }^{359}$ "There is no logical stopping point." "T660 "child benefit theory" thus has no reasoned limits and misses "the real issue, which is the nature of the benefit and its relationship to the 'Establishment Clause." "

The implicit rationale of the majority in the Everson decision suffers the same defect. It upheld public payment of bus transportation on the ground that the children were merely "receiving the benefits of public welfare legislation," ${ }^{132}$ yet suggested, in strongest dictum, ${ }^{303}$ that this was as far as the establishment clause would extend. But it must be granted that state subsidization of all secular education similarly affords

354 For judicial development of the theory, see Cushman, supra note 185, at 337-39. For description of the congressional attempt to fashion the Elementary and Secondary Education Act of 1965 to fit the theory, see Kelley \& LaNoue, The Church-State Settlement in the Federal Aid to Education Act, 1965 ReuIGION \& PUB. ORder 110 (D. Giannella ed.); Taylor, Federal Aid for Children and Teachers in All Schools, 12 Cathoric LAw. 193, 195 (1966).

855 Jones, The Constitutional Status of Public Funds for Church-Related Schools, 6

J. Church \& ST. 61, 72 (1964).

356 Id.

357 Jones, supra note 294, at 196.

858 Id. See also Giannella, supra note 199, at 572-81.

359 See, e.g., Note, 12 Mo. L. Rev. 465, 468 (1947) ; Comment, 6 U. Det. L.J. 174, 176 (1943).

360 Everson v. Board of Educ., 133 N.J.L. 350, 359, 44 A.2d 333, 339 (1945) (dissenting opinion). See also 35 CoNN. B.J. 119, 125 (1961); 1 BIIr of Rights REv. 307, 309 (1941).

361 Note, 41 IND. L.J. 302, 309 (1966).

362330 U.S. at 16.

3e3 See text accompanying notes 294-300 supra. 
children the benefits of public welfare legislation. ${ }^{384}$ The establishment clause should forbid no aid in that category. ${ }^{365}$

The Everson majority seemingly also sought to draw a lime by emphasizing that in the case at bar "the State contributes no money to the schools." ${ }^{368}$ On the basis of this reasoning, it has been concluded that "direct grants to sectarian schools are prohibited," assistance in the construction of general scliool facilities and for increasing teachers' salaries, to be administered by governmental agencies and made available directly to sectarian schools, are the clear case of what is proscribed by the Constitution."368

Closely akin to the "child benefit theory,"369 this rationale also places forn over substance. The constitutional result turns on the payee of money or recipient of property, whatever the primary effect of the government action or whoever the true ultimate beneficiary. ${ }^{370}$ It would invalidate a consignment of microscopes to a parochial school or a grant of funds to construct a science laboratory regardless of the clear secular purpose. "Similarly, if the only reasonable or practicable means of providing fire and police protection were to give a religious school public funds and have it perform this function itself, ${ }^{3371}$ such granting of funds would also be unconstitutional. Surely, it should make no constitutional difference if arithmetic textbooks are given to the parochial school rather than to the pupil or a public library from which he may withdraw them. ${ }^{372}$

It is argued by some that if direct grants to parochial schools do not violate the establishment ban, then nothing does except discrimination among religions, ${ }^{373}$ thus challenging the Supreme Court's unequivocal position that governmental support of all seligions is forbidden. ${ }^{374}$ Not true. Under the rationale I propose, governmental aid may not exceed the value of the secular services even where given to every religion.

It is contended that providing school bussing or laboratory equip-

304 See, e.g., P. Katuper, FrontIers of Constitutional Liberty 136 (1956); Boyer, Public Transportation of Parochial School Pupils, 1952 Wis. L. Rev. 64, 85; Comment, 21 S. CAL. L. Rev. 61, 75 (1947); Note, 60 HaRv. L. Rev. 793, 800 (1947); 3 InTrA. L. Rev. 147,153 (1948).

365 See Katz, Freedom of Religion and State Neutrality, 20 U. Cसr. L. REv. 426, 440 (1953).

366330 U.S. at 18. See text accompanying notes $296-99$ supra.

307 U.S. Dep't of Health, Education \& Welfare, supra note 20, at 361.

368 Id. at 373. Cf. P. KAUPER, supra note 5, at 106-07.

300 See Cushman, supra note 185, at $34 \%$.

370 See Everson v. Board of Educ., 330 U.S. 1, 55-56 n.50 (1947) (dissenting opinion of Rutledge, J.).

371 Comment, 11 ST. Lours U.L.J. 464, 471 (1967).

372 Cf. Sky, supra note 42, at 1457-58. See text accompanying notes 530-33 infra.

373 U.S. Dep't of Health, Education \& Welfare, supra note 20, at 373-74.

${ }^{374}$ See note 59 supra (last paragraph). 
ment to a parochial school should be invalid because this makes "access to this public welfare benefit ... . dependent on conditions set by a religious group. These conditions will generally involve conformity to a religious creed or practice as the price for admission to the school and its publicly donated equipment."375 It may be true that "placing citizens in the position of having to accept church authority in order to obtain necessary public welfare benefits ... constitutes an establishment of religion." ${ }^{376}$ But it is not true that providing parochial schools with secular educational services has this effect. Under the rationale I propose, parochial schools would get no greater benefits than are already accorded public schools. Thus, access to the benefits is in no way dependent on the acceptance of churcli authority. ${ }^{377}$

Perhaps the greatest weakness in the "child benefit theory" and the "no money to the parochial school" rationale ${ }^{378}$ is that they permit public funds to be used for strictly religious purposes, beyond use for secular purposes, in contravention of a basic thrust of the establishment clause. Proponents of the "aid the child" approach advocate direct state subsidies to parents who may then choose any school for their children's education, ${ }^{379}$ subject to the state's right of accreditation. ${ }^{380}$ "Thus the schools would in no way be subsidized with public funds; only parents and their children would be subsidized." 381

No one denies that these subsidies would ultimately reach the parochial school's treasury; such a result would probably be a specific condition of the awards. ${ }^{382}$ After all, that is their precise purpose. Thus, if

375 LaNoue, supra note 60 , at 91.

370 Id. at 91-92. The free exercise claim is even more apparent.

377 Other considerations are present if the church-related school is in fact the only realistically available school. See text accompanying notes 436-39 infra.

$878 \mathrm{As}$ is true of other approaches to be discussed, both the "child benefit" and "no money to parochial school" rationales fail to fulfill their purported aims because of the freed funds factor, which produces precisely the effects they seek to avoid. See text accompanying notes 407-15 infra.

379 V. BuUn, Freedone of Chotce IN Education 29-30 (1958). See also Hayes, supra note 201, at 111; Note, 29 FORDFAM. I. REv. 578, 580 (1961).

380 The subsidy may take several analytically indistinguishable forms: (a) Direct appropriation. (b) Tax Credit. For discussion, see V. Bxun, supra note 379, at 19-22 passim. See also Freeman, Tax Credits and the School-Aid Deadlock, 194 Carmotrc Wordo 201, 207 (1962), for the view that a tax credit is "free from constitutional challenge . . . because it funnels out no public money and avoids contact between government and the private school." (c) Tax deduction.

881 V. BLusr, supra note 379 , at 30 .

382 See Brown, State Constitutions and Religion in Education, in Educatronal FreEDosr 163, 183 (D. McGarry \& L. Ward eds. 1966). "Since tuition charges are flexible and in Roman Catholic schools are often far below operating costs, the charges could readily be adjusted upward to take advantage of the parents' subsidies." Nelson, Proposal on the School-Aid Impasse, 78 Chrustian CenruRr 448, 449 (1961). See also Almond v. Day, 197 
the public subsidy exceeds the value of the secular educational service rendered, tax funds are being utilized for strictly religious purposes. ${ }^{\text {asa }}$ The parent subsidy theory fails to recognize this difficulty. Tax funds could be used for religion even if the amount given is only "equal to the sum expended on every child who attends the free schools," there is no guarantee that the parochial school offers the same quantum of secular education as the public schrools, nor that the lesser quantum offered costs the parochial school as much as the sum made available to it. ${ }^{385}$ The strictly religious use of tax monies could result even if the amount given is only "part of a tuition which is itself considerably less than the cost of education at the school attended," smaller governmental subsidy might exceed the cost or value of the secular educational service rendered. ${ }^{387}$

A "subsidy-to-the-parent-for-school-tuition" plan is not analogous to a government old age assistance program. ${ }^{388}$ In the latter instance the subsidized citizen may spend the money in any way he wislies, save it, or give it away. Government does not condition its grant, as it does the parent subsidy scheme, on the recipient's channeling the funds to a specific, limited class of ultinate beneficiaries, whicls class includes church-affiliated institutions.

That a person receiving old age assistance donates a portion to his church presents no colorable establishment clause issue. It is analytically

Va. 419, 426, 89 S.E.2d 851, 856-57 (1955); Lowell \& Southgate, POAU Position on ChurchState Relations, 5 J. CHuRCE \& Sr. 41, 51 (1963); Note, 36 FordFaMr L. REv. 129, 131 (1967); Note, 42 VA. L. REv. 437, 438-39 (1956).

383 This may explain the result in Swart v. South Burlington Town School Dist., 122 Vt. 177, 167 A.2d 514, cert. denied, 366 U.S. 925 (1961), which invalidated a tuition plan. The Vermont statute authorized payment of full tuition "but not in excess of $\$ 325.00$ unless authorized by a vote of the town school district," $122 \mathrm{Vt}$. at $179,167 \mathrm{A.2d}$ at 515 . The amounts appropriated to Roman Catholic high schools may have covered both secular and religious educational costs, although the opinion gives no indication. It lias been argued that "without doubt the real reason for the decision lay in the fact that tuition payments, which were made directly to the schools, were not in some manner apportioned to support of the nonreligious instruction given." Slough \& McAnany, supra note 37, at 69. See also Alciatore, Federal Aid to Church-Related Schools and the Constitution, 65 Carmoric Educ. REv. 383, 393 (1967); National Catholic Welfare Conference, supra note 37, at 420 n.54. The court's opinion affords scanty support for this view.

384 R. Drinan, supra note 50, at 196.

385 See discussion accompanying notes 183-199 suppa.

$388 \mathrm{~V}$. BLUM, sutpra note 379 , at 28.

887 It las been argued that a tax deduction, see note 380 supra, "would not corrupt the Constitution any more than the tax deduction now allowed those who make charitable donations to churches." THE REPORTER, Mar. 30, 1961, at 12. Perhaps the latter deduction survives attack on the ground that the benefit to the ultimate beneficiary religious groups does not exceed the value of the secular services they render. The topic, although obviously pertinent, is generally beyond the scope of the discussion.

388 Contra, V. BLum, supra note 379 , at 32-34. 
identical to a public employee's donating a portion of his compensation to his church. ${ }^{380}$ There is not the slightest government compulsion to ultilize tax funds for religious purposes. But a government condition that a tuition subsidy be transferred to some school of the parent's clroice (including a parochial school) is analytically identical to a state payment to any voluntary association that a recipient joins (including his cliurch or synagogue). Government has thereby restricted full freedom of choice as to how tax funds will be spent. It has singled out religion, albeit as part of a somewhat larger category, for government financial aid. If the ultimate religiously-affiliated beneficiary does not render secular services in return, tax raised funds will be used for strictly rehgious purposes. As has already been observed, ${ }^{390}$ this result is contrary to the underlying purposes of the establishment clause.

For these reasons, under the theory advanced in this article, certain provisions of the old "G. I. Bill of Rights" hishment clause. ${ }^{302}$ Under that bill, as reportedly administered, the government paid tuition directly to the veteran's scliool, even if it was a theological seminary. ${ }^{303}$ This was not a case in which "GI's are paid a certain amount which they can use in any way they want ... [as] compensation for their serving in the armed forces." 304 That would be like old age assistance. The G. I. Bill, however, was a case of "conditioned" benefits, within a fairly himited category, as described above. ${ }^{395}$

The funneling of tax money to theological seminaries appears to serve a strictly religious purpose. ${ }^{396}$ That this is "education they would

389 Cf. Rawlings v. Butler, 290 S.W.2d 801, 806 (Ky. 1956); Zellers v. Huff, 55 N.M. 501, 522, 236 P.2d 949, 961-62 (1951); Hysong v. Gallitzen Borough School Dist., 164 Pa. $629,656-57,30$ A. $482,483-84$ (1894).

390 See text accompanying note 60-66 supra.

301 Serviceman's Readjustment Act of 1944, 58 Stat. 287.

392 See Sullivan, Religious Education in the Schools, 14 LAW \& Contemp. Prob. 92, 109-10 (1949). But see Blum, Academic Freedom and Tax Support for Independent Education, 40 Per Derta Kappan, 349, 353 (1959).

303 Secretary of Health, Education \& Welfare, Federal Programs Under Which Institutions With Religious Affiliation Receive Federal Funds Througlı Grants or Loans, March 28, 1961 (memorandum), in S. Doc. No. 29, 87th Cong., 1st Sess. 37, 44 (1961). Blum, supra note 392 , at 352 , reports that "approximately 36,000 veterans used federal money to pay for training as Protestant ministers. ..."

394 Comment of Mr. Pfeffer, in Religion and Freedom, supra note 206, at 13.

395 It is of interest to note that the Higher Education Act of 1963, 20 U.S.C. \& 751 (a) (2) (1964), bars funds for use in divinity schools. See also PA. Const. art. III, § 18.

398 For the suggestion that there might be some exception due to an exercise of the war power, see Note, 8 LA. L. Rev. 141 n.20 (1947); cf. Bowker v. Baker, 73 Cal. App. 2d 653, 655, 167 P.2d 256, 257 (1946). But cf. Ex parte Milligan, 71 U.S. (4 Wall.) 2 (1866). Perhaps all or some of the tuition might be justified on the ground that clergymen perform a number of primary secular services. See also note 132 supra. 
have undertaken had they not been taken in the Army"807 is irrelevant. On this theory, the government could make contributions to any voluntary association to which the veteran had belonged because he would have done so had he been at home. Moreover, excluding theological seminaries from the Bill would not appear to have been a denial of free exercise for religion does not demand attendance there. ${ }^{308}$ Further, every veteran, whatever his religion, could have his tuition paid for secular education at any accredited institution, including those that are churchrelated. ${ }^{308}$

\section{C. "Earmarking"}

\section{Restricted Grants}

Another effort to draw a line regarding the constitutionality of aid to parochial education may be described as the "restricted purpose" or "earmarling" theory. Its thrust is that, where the public funds awarded to churcli-affiliated sclools-or to students attending them-are designated for specific secular purposes, the nonestablishment precept is satisfied because such grants, unlike more general grants, would not finance religious functions. ${ }^{400}$ Thus, allocation of public funds for improving secular educational methods, construction of dormitories, acquisition of science, mathematics and foreign language equipment, ${ }^{401}$ textbooks also used in public schools, ${ }^{402}$ and scientific and medical research ${ }^{408}$ are valid. ${ }^{404}$ On the other hand, governmental appropriations "with no restrictions and no direction as to the purposes for which the money can be spent would be unconstitutional."

The majority opinion in Everson lends some support to this "restricted purpose" theory. It spoke of bus transportation, ordinary police and fire protection, connections for sewage disposal, and public highways

3072 Hearings on H.R. 2361, supra note 35 , at 1614 .

308 Cf. note 59 supra. See also note $\mathbf{5 5}$ supra.

399 See State ex rel. Atwood v. Johnson, 170 Wis. 251, 176 N.W. 224 (1920).

40052 IA. L. Rev. 571, 574 (1966). Cf. Kauper, Separation of Church and State-A

Constitutional View, 9 CATHOLIC LAW. 32, 42 (1963).

401 See U.S. Dep't of Health, Education \& Welfare, stupra note 20, at 375-76.

402 See id. at 368; Borden v. Louisiana State Bd. of Educ., 168 La. 1005, 123 So. 655,

661 (1929).

403 See Lowell \& Southgate, supra note 382 , at 52-55.

404 Some would distinguish among these items. Thus, of those items mentioned in the text, Protestants and Other Americans United (POAU), see id., would seem to approve only of research grants. But simce all serve strictly primary secular purposes, they appear analytically indistinguishable. In fact, it has been pointed out that research grants afford the recipient institution significant additional assistance in attracting strong faculty, "enriching the educational program, developing better facilities, drawing higher quality students, and diversifying sources of income." Kratz, supra note 193, at 210.

405 5. Hearings on S. 370, supra note 148, at 2524 (Statement of Senator Morse). 
and sidewalks as "general government services ... separate and ... indisputably marked off from the religious function."

\section{Freeing of Funds}

The "restricted purpose" or "earmarking" rationale, however, is not a viable constitutional test. Althougl use of the public funds may be strictly limited to the ends designated, their allocation releases additional church funds for strictly religious purposes ${ }^{407}$-be it for religious proselytizing, the purchase of religious insignia, or any of a countless number of other purely religious ends. Because of this "freed funds" effect-hardly a matter that may be deemed "immaterial" 408 by the advocates of this rationale-the theory effectively fails to fulfill its own purposes and places form over substance.

To avoid this consequence, it has been argned that a grant may be "earmarked for a specific purpose which would not otherwise be undertaken by the recipient . . ." ${ }^{309}$ But this is an inquiry more easily stated than demonstrated. For example, that the cost of textbooks or transportation had formerly been borne by the parents, ${ }^{410}$ does not mean that their provision now by the state will not provide additional funds to the religious institution. ${ }^{411}$ The latter could now easily and justifiably increase its tuition charge, thus providing it with funds available for strictly religious use. ${ }^{412}$

Even if the property or service which the government finances had not previousily been part of the parochial school's-or parents'-activities, it caunot be said with any confidence that funds are not freed. It

406330 U.S. at 17-18. Since these serve strictly secular purposes, it is difficult to distinguish them, on this "earmarking" analysis, from other such services. But see text accompanying note 443 infra.

407 See Letter from Professor Sutherland to Senator Morse, in S. Doc. No. 29, 87th Cong., Ist Sess. 60 (1961); 79 Christian Century 617 (1962) (editorial); 77 HaRv. L. Rev. 1353, 1354 (1964); 59 MICH. L. REv. 1254, 1255 (1961).

408 Opinion of the Justices, 99 N.H. 519, 522, 113 A.2d 114, 116 (1955).

409 U.S. Dep't of Health, Education \& Welfare, supra note 20, at 370. See also Moore, supra note 334, at 161. The Elementary and Secondary Education Act of 1965 attempts to meet this qualification. It forbids grants for instructional materials if institutional funds would ordinarily have been used for like materials, 20 U.S.C. $\$ 823$ (a) (5) (Supp. I, 1965), and for specialized educational services if normally provided by the nonpublic school, 45 C.F.R. \& 116.19 (d) (1967).

410 In respect to textbooks, see Board of Educ. v. Allen, 27 App. Div. 2d 69, 72, 276 N.Y.S.2d 234, 238 (1966). Regarding transportation, compare Comment, Hospital Aid and the Establishment Clause: Conflict or Accomodation, 13 U.C.L.A.L. REv. 1100, 1107 (1966), with L. Prefrer, supra note 26, at 178; State ex rel. Reynolds v. Nusbaum, 17 Wis. 2d 148, 152, 115 N.W.2d 761, 763 (1962).

411 But see Cochran v. Board of Educ., 281 U.S. 370, 375 (1930); LaNoue, supra note 60 , at $80 ; 36 \mathrm{KY}$. L.J. 228, 330-31 (1948).

412 See note 382 supra. 
would be extremely difficult to prove that the parochial school, or the parent, would not have itself undertaken the matter in the near future ${ }^{413}$ -the question not infrequently turning on the subjective thoughts of the school's administrators or all parents, or on the credibility of their testimony in respect thereto. In addition, a court may "be compelled to examine the financial structure of the school, its previous success or failure in fund-raising campaigns, and the proposed allocation of its resources."414 This approach might produce an undesirable situation whereby the parochial school administrators or the parents would defer providing a particular service because to provide it now would make a subsequent government subsidy unconstitutional. Finally, it would be virtually impossible to prove that the parochial school would never have itself undertaken the project-be it special remedial reading, field trips, special tutoring, or even a "head-start" program.115 It is more natural to assume that any service provided by public schools is also within the reasonable contemplation of parochial schools.

"Earmarking" is of no consequence under the rationale proposed in this article. Nor is the freeing of funds which is an effect of even police and fire protection. ${ }^{416}$ Rather, the crucial inquiry is whether the total government assistance exceeds the value of the secular educational service rendered. The state funds may be paid to the parent or directly to the school so long as they serve a primary or independent secular purpose, as defined herein.

Even if the parochial school endorsed the government's bank draft directly to a seller of religious books or insignia, it should be of no constitutional significance; ${ }^{417}$ this is logically no different than the school's endorsing the draft to a seller of dictionaries or bus transportation, and then drawing a check on funds in its own account-which it would otherwise have used for the dictionaries or bus transportation-to pay for the religious books or insignia. Even if the state, at the parochial school's request, were itself to supply religious tracts to the school ${ }^{118}$ unlikely as this may be-there should be no issue if the total public appropriation to the school were not greater than the value of the secular services rendered; this is analytically the same as the state supplying dictionaries to the parochial school and the school then buying the reli-

413 See Note, The Elementary and Secondary Education Act of 1965 and the First Amendment, 41 IND. L.J. 302, 314-315 (1966); Comment, stupra note 410, at 1107.

41441 N.Y.U.L. REv. 983, 986 (1966).

415 See Catholic Schoot J., June 1965, at 13-15.

416 See note 185 supra.

417 Cf. State ex rel. Nevada Orphan Asylum v. Hallock, 16 Nev. 373, 387-88 (1882).

418 But see Board of Educ. v. Allen, 20 N.Y.2d 109, 121, 228 N.E.2d 791, 797, 281 N.Y.S.2d 799, 808 (1967) (dissenting opinion). 
gious tracts with the funds freed. Of course, the state should not be able to condition its grant on use for religious purposes. In that case, although the parochial school might use the funds thus freed for secular purposes, the grant would not assure this result. Only a religious end would be guaranteed, and by conscious government dictate. This the establishment clause forbids without further inquiry or computations. ${ }^{419}$

\section{Child Benefit "Revisited"}

Having considered the "child benefit" and "earmarking" theories, what may be termed the "LaNoue-child benefit revisited" theory merits some attention. Mr. LaNoue submits three criteria as the bases for a constitutional formulation respecting aid to parochial schools: ${ }^{420}$ First, if the aid goes directly to the parent or child, no religious institution should acquire new property through the state action. (The shortcomings of this criterion have already been fully explored. ${ }^{421}$ ) Second, all control over administration and spending of the public funds should remain with the state-for example, the state should select any textbooks provided. ${ }^{422}$ (But, whoever the selecting agency, establishment clause values are preserved if the book is to be used for a primary secular purpose. ${ }^{423}$ ) Third, no religious use should be made of what the state provides. (This ignores the freed funds effect. ${ }^{424}$ )

\section{E. Aid to Hospitals Distinguished}

Government grants and loans for hospital construction, to institutions including those that are church-affiliated, ${ }^{425}$ generally conceded to present no establishment clause problems, ${ }^{428}$ are analogous to public financing of the secular aspects of parochial education. ${ }^{427}$ Just as the state may

$410 \mathrm{Cf}$. text following note 158 .

420 LaNoue, supra note 60 , at $90-91$.

421 See discussion in text accompanying notes 354-390 supra.

422 Cf. Chance v. Mississippi State Textbook Rating \& Purchasing Bd., 190 Miss. 453, 462, 200 So. 706, 708 (1941); Board of Educ. v. Allen, 20 N.Y.2d 109, 116, 228 N.E.2d 791, 794, 281 N.Y.S.2d 799, 804 (1967); W. VA. Code ANN. § 1782(2) (1961).

423 For elaboration, see discussion accompanying notes 200-80 supra. See also text accompanying notes $464-65,520-33$ infra.

424 See text accompanying notes $407-15$ supra.

425 The Hospital Survey and Construction Act, 42 U.S.C. \$ 291 (1964), better known as the Hill-Burton Act, authorizes grants and loans for up to two-thirds of the cost of construction of general hospitals and other inedical facilities.

426 See text accompanying notes 303-11 supra.

427 In Quick Bear v. Leupp, 210 U.S. 50, 74 (1908), the Solicitor General argued, "A school, like a hospital, is neither an establishment of religion nor a religious establishment, although along with secular education there might be, as there commonly is, instruction in morality and religion, just as in a hospital there would be religious ministrations." While there may be differences in degree beyond those he indicated, they should not be consequential for establishment clause purposes. See discussion at notes 428-39 infra. 
"care for the destitute ill," advancement of its citizenry. To paraphrase Mr. Pfeffer, "As long as the sum paid to the denominational [school for the cost of its nonreligious education] does not exceed the amount the state would be required to expend to [provide this education in public schools], the [parochial school] is not really receiving government aid." ${ }^{228}$

The cases have been distinguished by some, principally on the grounds that admission to religiously-affiliated hospitals is on a nonsectarian basis and that the hospitals make no attempt to promote religious dogmas. ${ }^{430}$ Apart from the facts that at least Catholic parochial schools are not restricted to members of that faith, ${ }^{481}$ and that sectarian hospitals not infrequently have religious insignia in the rooms, ${ }^{432}$ have religiously significant requirements for doctors who may enter, ${ }^{438}$ and follow medical codes differing from that of the American Medical Association, ${ }^{434}$ there is a more constitutionally relevant response. When government funds are being expended only for primary secular purposes-either ministering to the sick or serving the secular educational needs of the young-the religious affiliation of the recipient institutions or those in attendance should be inconsequential-as should be the fact that "parochial schools are created specifically for rehgious as well as secular purposes." ${ }^{436}$

Religious restrictions on admission to an institution supported by public funds or such an institution's general religious tone should be similarly irrelevant constitutionally so long as the benefits provided may convemently be obtained elsewhere. ${ }^{486}$ On the other hand, if "the gov-

$428 \mathrm{~L}$. PFEFFER, supra note 26 , at 201.

$420 \mathrm{Id}$.

480 Id. See also Lien v. City of Ketchikan, 383 P.2d 721 (Alas. 1963); Kentucky Bldg. Comm'n v. Effron, $310 \mathrm{Ky} .355,358,220$ S.W.2d 836, 838 (1949); Truitt v. Board of Pub. Works, 243 Md. 375, 404, 221 A.2d 370, 387-88 (1966); 62 Nw. U.L. Rev. 256 (1967); Comment, supra note 410 , at 1116.

431 For statistics, see 5 Hearings on S. 370, supra note 148, at 2547.

432 L. PFEFERR, supra note 26, at 201-02.

433 Id. at 202.

484 Lowell \& Southgate, supra note 382 , at 54.

435 Note, The Elementary and Secondary Education Act of 1965 and the First Anendment, 41 IND. L.J. 302, 321 (1966).

${ }^{480}$ See text accompanying notes 375-77 infra. But see Giannella, supra note 199, at 528, 554,589 . Likewise, the fact that denominational social welfare units "believe that all children of their faith should be cared for by agencies representing the same faith," R. WERNER, Publyc Financtivg of Voluntary Agency Foster Care 141-42 (1961), should not disqualify them for public financial assistance.

The decision in Simkins v. Moses H. Cone Menorial Hospital, 323 F.2d 959 (4th Cir. 1963), cert. deried, 376 U.S. 938 (1964)-holding that "private" hospitals receiving HillBurton Act funds and participating in a federal-state progran for satisfying community hospital needs were sufficiently involved with "state action" to be subject to the fifth and fourteenth amendments' prohibitions against racial discrimination-is sometimes cited for the proposition that religious institutions receiving governmental aid may similarly be charged 
ernment has chosen to aid a religious institution to save the expense of building new public facilities" ${ }^{437}$ or has "granted a government financed monopoly over certain services in a particular geographical area,"438 the result may be different. Under these circumstances, an otherwise private institution is performing what has traditionally been, or what has effectively become, a "public function." Therefore, there is a forceful argument that it should be subject to the "state action" restrictions of the Constitution ${ }^{439}$ - that either governmental assistance must be terminated or the institution must be bound by the constitutional obligations of the state.

\section{F. Balancing}

Probably the most forthright school of thought that wishes to have the Constitution permit some public financial assistance to parochial

with the obligations of the state. Thus, it is argued that publicly assisted church-related schools and hospitals may constitutionally be barred from giving any religious preference in the choice of admittees, administrators and staff, from conducting religious observances, and even from placing religious symbols in rooms. Comment, Public Control of Private Sectarian Institutions Receiving Public Funds, 63 MrcH. L. REv. 142 (1964). See also P. KAUPER, supra note 5, at 116-18; Kelley, Protestants and Parochial Schools, 79 Commonweal 520 (1964).

But the Simkins case is distinguishable on several grounds. First, the court noted that it did not merely rely on the fact that the recipient hospitals were publicly financed. It stressed that the hospitals operated "as integral parts of comprehensive joint or intermeshing state and federal plans or programs designed to effect a proper allocation of available medical and hospital resources for the best possible promotion and maintenance of public health." 323 F.2d at 967. Thus, the court was impressed with the argument that these private lospitals were performing a "State function," $i d$. at 968 , that is, that they served in fact as substitute facilities for those the state would have otherwise provided and that the state selected them to be put to this use. See text at notes 437-39 infra. See also Lewis, The Meaning of State Action, 60 CoLuMr. L. REv. 1083, 1104 n.77 (1960). This "state function" notion is not to be confused with the fact that these hospitals (like nonpublic schools or other private hospitals) were simply rendering pubiic services that other existing state institutions also happen to provide. But see Comment, supra, at 146-47.

Further, even if the fact that the hospitals were publicly financed is considered to be the crucial ingredient, there is a vital distinction between "state action" of this kind involving racial discrimination and "state action" of this kind involving religious preferences and observances. A publicly supported "private" institution's claim of right to racial discrimination is weak at best. But a publicly supported church-affiliated school's contention that religious preference for students and faculty is necessary or desirable for execution of its purposes raises a substantial claim under the free exercise clause. Similar and even stronger claims may be made for religious observances and insignia. See generally Henkin, Shelley $v$. Kraemer: Notes for a Revised Opinion, 110 U. PA. L. Rev. 473 (1963); Horowitz, Fourteenth Amendment Aspects of Racial Discrimination in "Private" Housing, 52 CarIs. L. REv. 1 (1964); Van Alstyne \& Karst, State Action, 14 STav. L. Rev. 3 (1961).

437 LaNoue, supra note 60 , at 92 n.75.

$498 \mathrm{Id}$.

439 See Evans v. Newton, 382 U.S. 296 (1966); Pubhic Utilities Comm'n v. Pollak, 343 U.S. 451 (1952); note 436 supra. The "public function" issue is generally beyond the scope of the discussion. For further consideration, see W. LOCKHART, Y. KAMTrSar \& J. CHOpER, Constrtotronar LAw 1235, 1290, 1293, 1322-25 (2d ed. 1967). 
education but forbid public subsidization of all the secular aspects is that which contends that "today ... most of the distinctions of the law are distinctions of degree." $" 440$ The view is that the Court must decide "when a little becomes too much," balancing the many competing considerations and ultimately weighing them on policy considerations." ${ }^{242}$ The Everson majority's clear implication that bus transportation lay at the brink of unconstitutionality ${ }^{443}$ may be relied on for substantiation. .44 $^{44}$

This test is sometimes phrased in terms of a "direct-indirect"445 or "active-passive" standard. ${ }^{46}$ But, in essence, the approach requires the Court to juggle a nearly infinite number of diverse factors-for example, whether the state's purpose is rehioious or secular, the importance in terms of priorities of the public purpose, the relative probability of its accomphishment, the type and quantum of benefit given to religion, whether funds will be freed, the relative strength of sectarian influences operative within a particular recipient institution, the relationship of the benefit to the religious aspects of the institution aided, the extent to which the state selects the institutions to be aided. These, in turn, must be measured by the implications of the free exercise clause as tempered by the force of the establishment clause, considered in light of the existence and adequacy of alternative ineans, and perhaps bolstered by a presumption of unconstitutionality (or maybe constitutionahity). ${ }^{447}$

The defect of this approach is by now apparent. If "the method of weighing constitutional objectives in order to choose among them affords no guidance for further action, except on what Holnnes called a 'pots and pans' basis," ${ }^{\prime 48}$ then subjective assessment of the multitudinous elements at issue here is presumptively inappropriate for an independent judiciary as we know it. Only in limited and compelling circumstances is such a process even justifiable, much less desirable. ${ }^{440}$ The advocates of this approacl themselves acknowledge that, as applied to aid to parochial

440 Panhandle Oil Co. v. Knox, 277 U.S. 218, 223 (1918) (dissenting opinion of Holmes, J.).

441 Sutherland, supra note 85 , at 1310 .

442 Note, 52 CoRNerr L.Q. 814, 826 (1967). See also Moore, supra note 334, at 192-93. 443 See discussion at note 295 supra.

444 See U.S. Dep't of Health, Education \& Welfare, supra note 20, at 368-69. See also Horace Mann League v. Board of Pub. Works, 242 Md. 645, 671, 220 A.2d 51, 65, cert. denied, 385 U.S. 97 (1966).

445 See Hayes, supra note 201, at 108.

446 See Note, 8 LA. L. Rev. 136, 140 (1947).

447 See generally U.S. Dep't of Health, Education \& Welfare, supra note 20, at 365-73;

Comment, supra note 410, at 1109-14. See also Note, 52 Corveli L.Q. 814, 826 (1967);

Note, 8 LA. L. REv. 136, 140 (1947).

448 Kurland, supra note 19 , at 96.

449 See text accompanying notes $32,117-20,337$ supra. 
schools, "it is futile to hazard a prediction of the outcome" the consolation to "[t] hose who see no distinction between transportation and any other form of assistance whatsoever [is that they] should keep in mind that, apparently, the Court [in Everson] did." 451

\section{G. Horace Mann}

The recent, celebrated Horace Mann decision in Maryland, ${ }^{452}$ invalidating under the establishment clause the allocation of state funds to three of four church-related colleges for construction of science and classroom buildings, a diming hall, and a dormitory, employed a somewhat more himited but analytically similar balancing approach. The state court, interpreting the relevant Supreme Court opimons as barring any direct grants to "sectarian" institutions, ${ }^{453}$ utilized a six-criteria formula to determine whether each recipient college met this test. ${ }^{454}$ The court itself recognized the inappropriateness of this constitutional approach-"to decide each case upon the totality of its attendant circumstances." ${ }^{\text {"455 }}$ It admitted that application of its test was "a rather elusive matter, being somewhat eplemeral in nature."456

The more basic defect in the Horace Mann decision was that, for establishment clause purposes, ${ }^{457}$ it ignored the fact that, no matter how "sectarian" the recipient college, the state expenditures seemingly served a primary secular purpose; ${ }^{458}$ undoubtedly, the colleges found to be "sectarian" receive inany indirect public benefits that "aid" them as significantly as the funds in issue. ${ }^{459}$ Thus, to bar all direct governmental

450 Moore, supra note 334, at 193.

461 U.S. Dep't of Health, Education \& Welfare, supra note 20, at 369.

452 Horace Mann League v. Board of Pub. Works, 242 Md. 645, 220 A.2d 51, cert. denied, 385 U.S. 97 (1966).

$458242 \mathrm{Md}$. at $654-72,220 \mathrm{~A} .2 \mathrm{~d}$ at 55-66.

454 The court examined in detail (a) the college's stated purposes, (b) the college personnel, (c) the college's relationships with religious organizations and groups, (d) the place of rehigion in the college's program, (e) the product of the college program vis-á-vis accreditation and character of activities of alumni, (f) the work and image of the college in the community. Id. at $672,220 \mathrm{A.2d}$ at 65-66. For a nore direct, less complicated approach, under a state constitutional provision, see Collins v. Kephart, 271 Pa. 428, 117 A. 440 (1921).

455242 Md. at 678,220 A.2d at 69.

450 Id.

457 The court, in rejecting attacks under the Maryland constitution, held that the expenditures were "for public purposes." 242 Md. at 685, 220 A.2d at 73.

458 See Drinan, The Challenge to Catholic Education in the Maryland College Case, Nat's Cathoric Educ. Ass's. Burl., May 1967, at 3, 5.

450 For example, various forms of student scholarships and assistance. See note 382 supra; Brown, supra note 382, at 182-83; Blum, supra note 37 , at 147-48; 3 Hearings on S. 600 Before the Subcomm. on Educ. of the Senate Comm. on Labor and Public Welfare, 89th Cong., 1st Sess, at 1226 (1965) (Statement of Lawrence Speiser, Director, Washington ACLU). 
grants to church-affiliated educational institutions simply because they engage in certain practices that foster religion, while acknowledging that "not every activity of a religious group is necessarily a religious activity," ${ }^{460}$ not only jeopardizes a host of existing state and federal programs, ${ }^{461}$ but places form over substance and is constitutionally unsatisfactory.

\section{H. Manipulation}

\section{Lending Textbooks}

The test for determining whether governmental assistance to religion breaches that neutrality demanded by the first amendment, it has recently been argued, should be whether "the aid could be mampulated by church or state to dominate the other." ${ }^{462}$ The aid involved, for example, in the Allen case now pending before the Supreme Court ${ }^{463}$-lending secular textbooks to parochial school students-is found to violate that standard on several counts.

First, "since textbooks are used in the classrooms as an integral feature of the educational process, there is no certainty that they would not be manipulated for rehgious instruction in parochial schools." ${ }^{464}$ True. But even assuming that similar manipulation could not occur with respect to state-provided school lunches (by prayers in connection therewith, for example), or state-financed school medical examinations (by their illustrative use in classroon theological discussions), or state-laid sidewalks providing access to the denoninational school, the point is not well taken. Even public aid that is itself immune from sectarian manipulation frees church funds either for uses subject to manipulation, or for strictly religious uses. This being so, the attempted linitation only formalistically accomplishes the end sought. The sole criterion should be whether the total public support exceeds the value of the secular service rendered. If allegedly secular activities are so manipulated as to be no longer fairly characterized as nonreligious, they may not be included in valuing the secular service provided. ${ }^{465}$

Second, it is contended that lending textbooks "will create and foster a pressure to dominate the choosing of books that shall be used in the public schools (so that they may also be used in parochial schools)."186

4603 Hearings on S. 600 , supra note 459 , at 1223 (Statement of Lawrence Speiser, Director, Washington ACLU).

461 See Davidow, supra note 131, at 668-69.

402 Note, 36 GEo. WaSH. L. REv. 246, 250 (1967).

463 Board of Educ. v. Allen, 20 N.Y.2d 109, 228 N.E.2d 791, 281 N.Y.S.2d 799 (1967), prob. juris. noted, 36 U.S.L.W. 3278 (U.S. Jan. 15, 1968).

464 Note, 36 GEO. WASH. L. REv. 246, 249 (1967).

465 See text accompanying notes 200-80 supra.

466 Note, 36 GEo. WASH. L. REv. 246, 250 (1967), quoting from the dissenting opinion 
That may be true. But if such pressures occur and are unconstitutional, ${ }^{467}$ they should be dealt with specifically rather than by striking an entire program. And, however irresistible such pressures would be, they seemingly exist even in the absence of the program because approximately half of Catholic children presently attend public schools. ${ }^{468}$

\section{Control Follozes Aid}

Fimally, it is urged that if "parochial schools become dependent on state financing of books for children, mampulative conditions could attach which would compel sectarian schools to restrict religious instruction or which could ultimately result in dissolution of a separate parochial system altogether." ${ }^{469}$ This "control follows aid" assertion, frequently heard ${ }^{470}$ and already referred to, ${ }^{471}$ deserves further consideration.

It was said ten years ago that "examination of the state constitutional and statutory provisions reveals little public control of private schools and teachers." ${ }^{\prime 42}$ An authoritative and comprehensive federal study reported at that time that in only five states do departments of education "have exphicit statutory responsibilities for the certification of teachers of nonpublic schools, ${ }^{473}$ and indicated that curriculum regulation was indeed mimimal. ${ }^{474}$ And there is bittle reason to believe that much significant change has taken place since then. ${ }^{475}$

It is argued that increased state financial assistance to parochial schools will bring additional state supervision because it is "discrimi-

in Board of Educ. v. Allen, 20 N.Y.2d 109, 123, 228 N.E.2d 791, 798, 281 N.Y.S.2d 799, 810 (1967) prob. juris. noted, 36 U.S.L.W. 3278 (U.S. Jan. 15, 1968).

407See also discussion in text accompanying notes 67-74 supra.

$408 \mathrm{~L}$. PFEFFER, supra note 26 , at 510 .

469 Note, 36 GEO. WASE. L. REV. 246, 249-50 (1967).

470 See, e.g., Everson v. Board of Educ., 330 U.S. 1, 27 (1947) (dissenting opinion of Jackson, J.); Gurney v. Ferguson, 190 Okla. 254, 256, 122 P.2d 1002, 1005 (1941); Davidow, supra note 131, at 683.

471 See note 436 supra.

472 Kohlbrenner, Some Practical Aspects of the Public Character of Private Education, 86 ScEool \& Soc'x 348, 351 (1958). In 1956, the National Education Association concluded that state supervision of nonpublic schools was "conspicuous by its absence rather than by its presence." State and Sectarian Education, 34 N.E.A. ReSEARCH BULL. 210 (1956).

473 F. BEACH \& R. WIII, supra note 27 , at 26.

474 Id. at 25 .

475 A 1964 study of state curriculum requirenients for nonpublic schools showed that 41 states provided for some regulation. But the instructional areas covered included only the following: common branches of education (31 states), U.S. Constitution (27), English language (26), American history (16), state constitution (16), other national documents (15), state and national civics (15), safety education (10), moral education (6), state history (6), other areas of special state interest (6), pliysical education (4). Stolee, Nonpublic Schools: What Mfust They Teach?, 92 Scroor \& Soc'y 274, 275 (1964), reprinted in 1 Hearings on S. 370, supra note 148, at 469. Further, in 15 of these 41 states, there was no enforcement whatever of the regulations. Id. at 470 . 
natory . . . to allow public funds to be spent by private schools without public control and yet insist on such public control for public schools."178 Perhaps this will be true as a realistic political natter. However, government may beheve controls are unnecessary or undesirable, and aid conditioned on controls thought unsatisfactory by the recipient may be refused. More importantly, as a constitutional matter, the state's power to regulate nonpublic scloools is wholly independent of any allocation of public funds. ${ }^{477}$ This is confirmed in practice by requirements already noted ${ }^{478}$ and by a number of others. ${ }^{479}$ On the other hand, public aid or not, the Constitution forbids unreasonable restriction of religious instruction or dissolution of the parochial school system.

The landmark decision of Pierce v. Society of Sisters ${ }^{480}$ is relevant on both counts. Invalidating a state requirement of compulsory public school education, the case held that due process of law forbids unreasonable state interference with parents' liberty to direct their children's education. The parental right being grounded in the Constitution, state authority to curtail it would not appear to be augmented by the grant of governmental funds. ${ }^{481}$ But Pierce also recognized state authority "reasonably to regulate all schools, to inspect, supervise and examine them, their teachers and pupils; to require ... that certain studies plainly essential to good citizenship must be taught, and that nothing be tauglit whicl is manifestly inimical to the public welfare."482

Those whose conscientious scruples constitutionally entitle them to attend a clrurch-related sclool plainly have no absolute right under the free exercise clause to maintain those schools free of state regulation, ${ }^{483}$ whatever the amount of public financial support given them. Although the state may have no right "to standardize its children by forcing them to accept instruction from public teachers only," ${ }^{484}$ to attain important

476 Bemis, What is Discrimination?, 42 PmI Dexta Kappan 329 (1961).

477 See Brickman, Public Aid to Religious Schools, 55 Rurrgrous Edvc. 279, 287 (1960).

See also Whelan, Textbooks and the Constitution, 107 Asrerics 399, 401 (1962).

478 See note 475 supra.

479 See, e.g., 20 ME. Rev. StaT. ANN. § 1281 (1965) (commissioner shall establish requirements for accreditation including quality of instruction, school facilities and curriculum content); Mrcr. CoMpr. LAws ANN. \$§ 340.732(a), 388.551 (1967) (courses of study shall be comparable to and of same standard as in public schools); NEv. REv. STAT. § 394.130 (1963) (same instruction as is required in public schools, but no right to share in public school funds); N.Y. Edvc. LAW \$ 3204 (McKinney 1953), as amended, (McKinney Supp. 1967) (course of study for first eight years must include twelve designated subjects); N.C. GEN. STAT. § 115-255 (1966) (religious instruction should not be interfercd with but mimimum standards for courses of study must be met).

480268 U.S. 510 (1925).

481 See note 490 infra.

482268 U.S. at 534.

483 But see A. Jomsson \& F. Yosr, supra note 28 , at 139.

484 Pierce v. Society of Sisters, 268 U.S. 510, 535 (1925). 
societal goals it clearly may regulate action demanded by religion or conscience. ${ }^{485}$ This is especially true where the interests of children are concerned. ${ }^{486}$ Although the free exercise and due process clauses may assure private or sectarian schools the liberty "to inculcate whatever values they wish,"487 those clauses do not hamper the state's power reasonably ${ }^{488}$ to promote children's welfare through basic secular education. ${ }^{480}$ Thus, the "control follows aid" argument, as least as to its constitutional relevance, loses its force. ${ }^{490}$

\section{Accreditation}

By virtue of Pierce $v$. Society of Sisters, ${ }^{491}$ states must make it possible for parochial schools to gain accreditation. It is therefore contended that "public money . . . cannot logically be withheld from the private school if it is publicly accredited as an institution where children may fulfill their legal duty to attend school." ${ }^{492}$ This reasoning, acclaimed as the

485 Braunfeld v. Brown, 366 U.S. 599, 603-04 (1961); Cantwell v. Connecticut, 310 U.S. 296, 303-04 (1940).

486 Prince v. Massachusetts, 321 U.S. 158, 168 (1944).

487 School Dist. v. Schempp, 374 U.S. 203, 242 (1963) (concurring opinion of Brennan, J.).

488 In making the "accommodation between the religious action and an exercise of state authority [which] is a particularly dehicate task," Braunfeld v. Brown, 366 U.S. 599, 605 (1961), the state's interest in demanding that certain courses be taught would seem more substantial than its concern in forbidding inquiry into some field of knowledge. See Meyer v. Nebraska, 262 U.S. 390, 392 (1923) (argument for plaintiff in error). State control "need not be so restrictive that the independent school is precluded from having ample flexibility in determining how these common learnings will be taught, what additional subjects will be offered, what personal values will be imbued, and what experiments will be conducted." Fountain, A Plea for Public Support of Pluralism in America, 44 PEI DELTA KapPaN 415, 418 (1963). See Farrington v. Tokushige, 273 U.S. 284, 298 (1927). Nor should the state's requirements be so onerous as to preempt time for religious instruction. See Choper, supra note 4, at 392-93.

480 See State v. Garber, 197 Kan. 567, 419 P.2d 896 (1966), cert. denied, 389 U.S. 51 (1967), and cases there cited, 197 Kan. at 574-75, 419 P.2d at 902. See also 5 Hearings on S. 370, supra note 148, at 2073 n.21 (Statement of Edgar Fuller).

490 It has been contended that public financial assistance to parochial schools with resultant controls would be contrary to the prohibition in Everson v. Board of Educ., 330 U.S. at 16, of government participation "in the affairs of any religious organizations or groups and vice versa." Lowell \& Southgate, supra note 382, at 50. But the Everson opinion itself recognized that parochial schools must ineet "the secular educational requirements which the state has power to impose." 330 U.S. at 18. With or without financial assistance, this is not the government participation in religious affairs obviously referred to by the Court, its exact language notwithstanding. Further, if the state enters into a contract with a religious organization (here, for secular education), the state may enforce reasonable terms. Just as surely, the state nnay not "condition the availability of benefits upon .... [the recipient's] willingness to violate a cardinal primciple of ... religious faith." Sherbert v. Verner, 374 U.S. 398, 406 (1963).

401268 U.S. 510 (1925).

492 Drinan, The Constitutionality of Public Aid to Parochial Schools, in THE WACI between Church and State 55, 60 (D. Oaks ed. 1963). 
"strongest argument to sustain . . . general aid to parochial schools,"403 may be misleading.

The fact of accreditation should not be determinative. Under the estabhishment clause analysis proposed herein, a state could constitutionally "accredit" a parochial school course in religious instruction for the purpose of satisfying the minimum number of units required for graduation under state law. Since the purpose and effect of such a course could be religious-sectarian indoctrination-accreditation by the state would serve a primary religious end. But it would neither compromise anyone's rehgious scruples nor involve the use of compulsorily raised tax funds. ${ }^{494}$ However, for the state to support sucl an accredited course with public funds would have the latter effect and, therefore, should be held to violate the bar against establishment of rehion. Similarly, accreditation of a parochial school should not necessarily permit its being financed with public money on a par with schools that are not churcli-affiliated. The establishment clause should bar any grant of public funds exceeding the value of the secular services rendered.

\section{J. The Public Welfare-Educational Process Distinction}

Many opponents of public aid to parochial education, conceding the validity of certain " 'health' measures" 405 like free medical and dental services and free lot lunches for children in parochial schools, would draw the line there. Aid beyond this-in the form of scliool bus transportation, textbooks, or science equipment-is aid "to the educational process itself" ${ }^{\prime 98}$ and falls within the constitutional ban. Medical care and hot lunches are "true welfare benefits," it is contended, needed by a child "whether he goes to a public school, to a parochial school, or to no school at all."407 But school transportation and textbooks "are essential aids to the function of education as sucli . . . [and] cannot constitutionally be provided where the education is religious, since the function [aided] thus becomes religious education." ${ }^{408}$

493 Kurland, Politics and the Constitution: Federal Aid to Parochial Schools, 1 LAND \& WATER I. REV. 475, 491 (1966).

404 See text accompanying notes 51-53 supra; Choper, supra note 4, at 406-07.

405 Archer, Protestants Reply: The Bishops Demand Subsidy, U.S. NEWs \& WordD REPORT, Dec. 2, 1955, at 104, 105.

496 Statement of Mr. Greenawalt, in Dorsen, supra note 33, at 44. See also Tockman, The Constitutionality of Furnishing Publicly Financed Transportation to Private and Parochial School Students in Missouri, 1963 WASE. U.L.Q. 455, 491-92, 505; 33 CORNerr L.Q. 128 (1947); Comment, A Constitutional Analysis of the Wisconsin School Bus Lav, 1962 WIs. L. REv. 500, 516 .

407 L. PFEFFER, supra note 26, at 570.

408 Rosenfield, Separation of Church and State in the Public Schools, 22 U. Prrr. L. REv. 561, 580 (1961). This "which function is aided" theory seems first to have been developed at length by Cushman, supra note 185 , at $348-49$. 
This rationale may be challenged on a number of grounds. First, it is inconsistent with a conclusion drawn by its own advocates. The public welfare-education distinction would invalidate all school medical, nurse and dental care and milk and hot lunch programs for parochial school students. Although such services may be needed by every child, these state and federal programs do not "go to pupils as minor citizens . . . [but rather] to them as school-children." ${ }^{498}$ They are not provided to the unfortunately substantial number of school-age children not enrolled in any school, ${ }^{500}$ nor to children absent from school, nor to any children on those days when schools are closed. ${ }^{501}$ Similarly, this thesis would disquahify parochial school students from the benefit of such municipal services as school area traffic control devices ${ }^{502}$-including stationing traffic officers on school corners ${ }^{503}$-home instruction for those temporarily unable to attend school, the public library school bookmobile, school driver training, ${ }^{504}$ reduced rates by a publicly owned system for pupils traveling to school or school activities, ${ }^{505}$ and publicly sponsored educational television programs for classroom use. ${ }^{506}$

Conceding that "transportation, where it is needed, is as essential to education as any other element," and hot lunches. Hot lunches in particular, we know today, are no less important for many children than, as Mr. Justice Rutledge said of transportation, "the very teaching in the classroom or payment of the teacher's sustenance. Many types of equipment, now considered essential, better could be done without." ${ }^{208}$ Any distinction between them does not hold. ${ }^{509}$

But the more basic objection to distinguishing between medical care and school lunclies, on the one hand, and bus transportation, science

489 Williams, Church-State Separation and Religion in the Schools of Our Democracy, 51 Recrarous Edoc. 369, 373 (1956), who states the converse as being the fact.

500 In 1949, the National Education Association pointed out that there were then 4 million such children. 66 CHRISTIAN CENTORY 166 (1949) (editorial).

501 For illustrative description, see T. Powent, The Scrool Bus LAw 69-74 (1960).

502 See Rhoades v. School Dist., 424 Pa. 202, 211, 226 A.2d 53, 59, cert. denied, 389

U.S. 11 (1967).

503 See 25 Notre Dane Law. 367-68 (1950); 11 U. Pitr. L. Rev. 321 (1950).

504 See R. Dranan, supra note 50, at 138.

505 See id. at 139.

$50 B$ See 5 Hearings on S. 370, supra note 148, at 2538.

507 Everson v. Board of Educ., 330 U.S. 1, 47 (1947) (dissenting opinion of Rutledge, J.). Its cost has been estimated at "10 to 15 per cent of total school costs." Christian and Public Schools: Some Specific Problems, 40 PmI DeIta Kappan 302, 303 (1959).

E08 Everson v. Board of Educ., 330 U.S. 1, 48 (1947) (dissenting opinion).

${ }^{509}$ See Jobnson, Religion and Public Education, Buxx. OF NAT2 Ass'N OF SECONDARY Scrioor Prancrpass, April 1947, at 95, 97, suggesting that a lunch program should be viewed as direct aid to the school because "without it they would be forced by the competition of public schools to provide lunches at their own expense." See also Blum, Religious Liberty and Bus Transportation, 30 NoTre DaMre LAw. 384, 420 (1955). 
equipment, and the like, on the other, is that all of these items fulfill independent primary secular purposes. ${ }^{510}$ Even if they are all classified as essential to the educational function, ${ }^{511}$ none has the primary effect of aiding religious education in violation of the establishment clause..$^{612}$ A child needs secular education "whether he goes to a public school, to a parochial scliool, or to no school at all"; secular education is a "true welfare benefit." 513

The Everson dissenters found the bussing plan the same as furnishing "free carriage to those who attend a Church," "514 or paying "the cost of transportation to Sunday school, to weekday special classes at the church or parish louse, or to the meetings of various young people's religious societies." 1515 State action of these sorts would obviously violate the

510 The Everson dissenters complained that the reimbursement of parents for bus transportation costs was in no way related to "the child's safety or expedition in transit," 330 U.S. at 20 (Jackson, J.), because riding on public busses was "subject to all the hazards and delays of the highway and the streets." 330 U.S. at 60 (Rutledge, J.). But the New Jersey plan assured that children would ride busses to school whereas without compensation they might walk, drive their own cars, or be transported by busy parents or friends. Surely, the state could find that public busses provided for greater safety than the first two, and it was reasonable to believe that it might be more secure than the last. That the parochial school or the religious education therein was also benefited should be of no constitutional consequence. See Nichols v. Henry, $301 \mathrm{Ky} .434,443$, 191 S.W.2d 930, 934-35 (1946).

Even if the motivating consideration or main effect was not protecting children from traffic hazards but rather relieving the hardship of distance, see Board of Educ. v. Wheat, 174 Md. 314, 326, 199 A. 628, 634 (1938) (dissenting opinion); L. PFEFFER, stlpra note 26, at 567 , the primary purpose is no less secular. Perhaps "a child going to visit a neighbor or to a motion picture theatre is just as much subject to the hazards of the road as a child going to school," L. Pfeffer, supra note 26, at 566. See also Pfeffer, supra note 202, at 395-96. But see LaNoue, supra note 60, at 89. However, the fact that the state chooses only to safeguard the child going to school does not contradict its secular purpose. "The legislature may do what it can to accomplish what is deemed necessary for the public welfare, and stop short of those cases where the detriment to a few, not afforded state aid, is considered less important than the expense or inconvenience to the state which might result if the rule laid down were mathematically exact." Matthews v. Quinton, 362 P.2d 932, 957 (Alas. 1961) (dissenting opimion), cert. denied, 368 U.S. 517 (1962). See discussion in text accompanying notes 170-75 supra. Thus, the state may provide bus transportation for all school children, all poor school children, all school children who attend nonprofit schools (see discussion in text accompanying notes 170-75 stipra. But see Rhoades v. School Dist., $424 \mathrm{~Pa} .202,250,226$ A.2d 53, 85 (dissenting opinion), cert. denied, 389 U.S 11 (1967)), or all nonpublic school children who live on existing public school bus routes. But see Matthews v. Quinton, 362 P.2d 932, 940 (Alas. 1961), cert. denied, 368 U.S. 517 (1962). Public undertaking of any of these programs, like public funding of all secular educational costs, serves a primary nonrehigious purpose.

511 See Sherrard v. Jefferson County Bd. of Educ., 294 Ky. 469, 478, 171 S.W.2d 963,

967 (1943); Gurney v. Ferguson, 190 Okla. 254, 255, 122 P.2d 1002, 1004 (1942).

512 See discussion in text accompanying note 498 supra.

513 L. PFEFFER, supra note 497.

514330 U.S. at 24 (Jackson, J.). See also Powell, Public Rides to Private Schools, 17

HARV. EdUC. REv. 73, 82 (1947).

515330 U.S. at 47 (Rutledge, J.). 
establishment clause. Althougl a secular purpose would be served (convenience of citizens, protection against traffic liazards), it would be accomplished by unconstitutionally singling out one religion or all religions for preferential advantage. ${ }^{516}$

Aid to all schools, or all school children, or all school children in nonprofit sclools does not so discriminate. Such aid is as constitutionally nonpreferential as providing free carriage to all citizens or subsidizing all public transportation costs. Because these general programs have a priniary secular purpose, they should not violate the establishment bar when the transportation happens to be used to get to churcl, to religious meetings, or to parochial schools. The programs are logically the same as all other municipal services afforded all property without classification reflecting its religious ownership. ${ }^{517}$

It appears both logically and pragmatically ironical to contend $d^{518}$ that bus transportation for school children alone violates the establishment clause but that bus transportation for everybody, including school children, does not. The latter not only provides the same benefit to religious education as the former, but, unlike the former, it also subsidizes trips to Sunday school and clurch services. ${ }^{519}$ These apparent inconsistencies disappear under a rationale that looks to whether the government service provided - transportation and textbooks, for example - serves a primary secular purpose.

\section{K. The "Who Controls" Test}

Whether "it is the church (or church institution) or the state that perfornis or controls the performance of the services paid for by the state" lias been submitted as the "ultimate test," ment clause, for permitting public financial assistance to parochial education. Its basis is that "[i]t is reasonable to assume that services performed or controlled by a religious institution could and would be used to further the religious objectives of that institution, whereas services performed or controlled by a public body would be secular in purpose and fornI."

516 See text accompanying notes 159-60 supra.

517 State ex rel. Reynolds v. Nusbaum, 17 Wis. 2d 148, 157, 115 N.W.2d 761, 766 (1962). To say that, for religious property or activities, the establishment clause "forbids support, not protection from interference or destruction," Everson v. Board of Educ., 330 U.S. 1, 61 $\mathrm{n} .56$ (1947) (dissenting opinion of Rutledge, J.), is effectively to urge an untenable distinction between sidewalks and fire protection.

518 See discussion in text accompanying notes 495-98 supra.

519 See LaNoue, supra note 60 , at 89.

520 Gordon, supra note 229, at 92 .

521 Id. 
by a public bus," ficial to parochial school students and incidentally or indirectly of aid to the church institutions they attend." ${ }^{3623}$ But it would forbid the supplying of textbooks because "the use of texts in an educational context which is privately, rather than publicly, managed and administered directly serves a religious educational purpose."

\section{General Criticism}

The principal difficulty with this proposal is in its basic assumption. It is possible that a parochial school will so structure its services as to further, exclusively or partially, its religious objectives. If so, as was discussed earlier, ${ }^{525}$ such services cannot be supported by government to a greater extent than the value of the secular ends served. Further, it is clear beyond doubt that public schools may also so structure some of their services. ${ }^{526}$ If so, the courts must intervene when called upon. And it is also manifest that services controlled by a religious institution frequently do in fact further society's nonreligious objectives. ${ }^{527}$ If not, public financial support could not even be given to a religiously-affiliated hospital, a result apparently required by this thesis.

Transportation of parochial school children in a bus leased by the school would probably be described, under this approach, as a service "controlled" by the religious institution and thus the rental fee could not be paid by government. ${ }^{528}$ But bus transportation would nonetheless have a secular purpose. Even religious instruction given during the bus ride would not affect the primary secular purpose of safety and convenience. And if the government closed its fire department and instead paid any

$522 I d$.

523 Id.

$524 I d$, at 93 .

525 See text accompanying notes 200-80 supra.

528 See, e.g., cases cited note 2 supra.

527 The fact that a parochial school, in contrast to a public school, may have controlled admission policies and religious exercises and instruction to further its rehigious objectives, see G. LANour, supra note 56, at 29-30, sliould not affect the result. See discussion in text accompanying notes $375-77,436-39$ supra. To say that a school may not serve a public purpose or function because of these factors, see G. LANouE, supra note 56 at 34-35, is a misleading use of the word "public." Government is not restricted to supporting only activities that are "open to the public." It may finance action for a secular or public purpose even thougl undertaken by an institution not subject to public management or to the constitutional responsibilities of the state itself. See note 436 supra; Herberg, in Retuorow AND Freedom 18 (D. McDonald ed. 1958). May a person, wholly supported by public welfare be forbidden to discriminate racially in the purchase of necessary food and services?

528 Query, under this approach, if a publicly financed program of hot lunches, taken in the parochial school building, is a service controlled by church or state, especially if a school-directed blessing precedes and concludes it. 
private fire protection agency selected by the parochial school, the establishment clause should not invalidate this action. ${ }^{52 \theta}$

The "who controls" approach lias also been applied to library books. Mr. LaNoue argues that a constitutional distinction slould be drawn between housing books in a parochial school library on "indefinite' or 'permanent' loan" "removed ... o only for the period necessary for reasonable educational use ... for a textbook one seniester or one year." "531 But the purpose of either alternative is plainly secular; the "control" exerted over the books by the parochial scliool seems essentially the same; ${ }^{532}$ the public cost of each prograin appears identical, as does the benefit to the child and his school. This should not be the stuff of which constitutional distinctions are made.

$\mathrm{He}$ asserts that "since the books will not be centrally catalogued, students and teachers from other schools will be unable to borrow the public materials." 538 True. But so long as the primary purpose is secular and parochial schools are not given preference over other schools similarly situated, the fact should be of no constitutional significance.

\section{Shared Time}

Proponents of the "wlio controls" rationale would permit public financing of shared time or dual enrollment progranis ${ }^{534}$ in which parochial school pupils take part of their course work in the public schools. ${ }^{\mathbf{5 3 5}}$ Yet, not ouly would they bar use of these funds to pay for secular services of parochial schools, they would also invoke the establishment clause to

529 But see Gordon, stupra note 229 , at 92.

530 LaNoue, The Title II Trap, 47 PEI DeLta Kappar 558, 561 (1966).

$531 I d$. at 562. Mr. Pfeffer would distinguish constitutionally between public library books lent to parochial pupils for up to two weeks and those lent for six months. The latter is "in effect taking that book out of the public domain and putting it into private domain." 2 Hearings on $H . R$. 2361, supra note 35 , at 1631. But, contrary to his analogy, if adequate books are provided for all to borrow on a six month basis, this is not the same as a religious group appropriating a public park for six months. See also text accompanying note 532 infra, and following note 533 infra.

$632 \mathrm{Mr}$. Pfeffer would find a constitutional difference between public library loans to parochial school students of books, records and magnetic tapes, on the one hand, and equipment for playing the records and tapes, on the other. 2 Hearings on $H . R$. 2361, supra note 35 , at 1619. This surely is irrelevant in terms of "wlo controls." It would seem, under that theory, that libraries would be barred from any loans to parochial school students for school use.

533 LaNoue, supra note 530.

634 See G. LANout, supra note 56, at 43-44; L. PFEFrER, supra note 26, at 578-79. See also Note, 65 MrCH. I. REv. 1224, 1231 (1967). But see American Civil Liberties Umion, Position on Shared Time, Apr. 4, 1965.

535 For discussion of rulings under state constitutions, see Katz, Note on the Constitutionality of Shared Time, 1964 RELIGION \& PUB. ORDER 85, 89-94 (D. Giannella ed.). 
forbid public school instructors teaching courses in the parochial schools themselves. ${ }^{630}$ Therefore, the very same public school teacher who taught, say, a section of a course in home economics or geography to a class including parochial school students, as part of a shared time program in the public school, could not teach the same course at the parochial school at what might very well be the same total public expense. Nor would it appear that a publicly hired speecli therapy ${ }^{637}$ or driver training ${ }^{538}$ teacher could instruct parochial pupils at the cliurch-affiliated scliool. ${ }^{630}$ of course, these results would not obtain under the establisliment clause approacl suggested in this article. ${ }^{\mathbf{5 4 0}}$

(a) Parochial School Representation.-The fact that a parochial school representative may participate with public school officials in the plannimg and admmistration of shared time programs ${ }^{541}$ has been condemned under the establisliment clause. ${ }^{542}$ But this is not the type of religious participation in the affairs of government ${ }^{543}$ that must be thwarted. If the participant seeks to inject religion into the shared time curriculum, le may not do so. But if his participation is addressed to secular educa-

5362 Hearings on H.R. 2361, supra note 35, at 1618 (testimony of Leo Pfeffer).

537 See Special Dist. v. Wheeler, 408 S.W.2d 60 (Mo. 1966). Under the Elementary and Secondary Education Act of 1965, public school personnel are providing remedial instruction in mathematics and reading on parochial school premises. The question is raised in Polier $v$. Board of Educ., a pending case described in American Jewish Congress, supra note 6, at 4. The National Defense Education Act of 1958 finances state plans for academic testing of nonpublic school students. 20 U.S.C. $\$ \S 483(\mathrm{a})(1), 484$ (b) (1965). Apparently this could be done by public personnel in parochial schools. See generally, 1 Hearings on S. 370, supra note 148 , at $471-72$.

538 But see 2 Hearings on H.R. 2361, supra note 35, at 815 .

539 Query as to extension of home teaching services to physically handicapped children who will return to parochial schools. See Scales v. Board of Educ., 41 Misc. 2d 391, 245 N.Y.S.2d 449 (Sup. Ct. 1963).

540 Professor Kurland suggests that shared time programs "have no rationale except benefit for church schools," (supra note 493, at 494. Seb also Burton, Public Funds for Public Schools Only, 78 CHRISTIAN CENTURY 415, 417 (1961)) and therefore violate the first amendınent. But, while seemingly judging legislative "motive," see text accompanying notes 103-04 supra, this disregards the clear effect of these programs which seck broader distribution of public funds to the goal of an improved secular education for all. If only parochial school students could participate, the issue would be different. See text at notes 159-60 supra. The dual enrollment provision in Title $I$ of the Elementary and Secondary Education Act of 1965 requires participation "of educationally deprived children . . . who are enrolled in private elementary and secondary schools" 20 U.S.C. \& 241e(a)(2) (Supp. I, 1965) (emphasis added).

541 See Elementary and Secondary Education Act of 1965, 20 U.S.C. $\$ 844$ (a) (Supp. I, 1965).

5421 Hearings on H.R. 13160 and $H . R .13161$ Before the General Subcomm. on Education of the House Comm. on Education and Labor, 89th Cong., 2d Sess., at 340 (1966); 2 Hearings, on H.R. 2361, supra note 35, at 1610-11; Note, stcpra note 435 , at 316 .

543 See note 490 supra. 
tional concerns, no establishment issue should arise. Surely, a meeting of government officials and community leaders to discuss publicly funded programs for riot prevention may constitutionally include clurch representatives, who may suggest a secular role that their institutions might play.

(b) Preference to Catholicism.-Especially in respect to shared time, ${ }^{544}$ it has been alleged that public financial aid to parochial schools is in fact preferential aid to Roman Cathohicism because that religion is the principal one engaged in the field of education ${ }^{545}$ whereas other denominations emphasize different endeavors. ${ }^{546}$ But numerous civil regulations for secular purposes affect the interests of different religious groups disproportionately-obvious examples being laws requirmg Sunday closing, enforcing monogamy, and prohibiting usury. ${ }^{547}$ So long as the state's purpose and primary effect is nonrehgious, the establishment ban should be held satisfied.

\section{Higher Education Distinguished}

It is frequently asserted that aid to church-related colleges and universities is constitutionally distinguishable from aid to elementary and secondary parochial schools..$^{548}$ The principal reason advanced is that college attendance is voluntary, ${ }^{549}$ whereas public support of parochial schools is support of coerced rehgious instruction. ${ }^{550}$ There is httle doubt that, if children are assigned by public authority-that is, coerced-to attend what is in effect a parochial school, their first amendment rights of rehioious liberty have been breached, whatever their rehgious faith. Public support of the school under those circumstances merely compounds the evil..51 But, in the usual case, government compulsory education laws coerce no child to attend a parochial school, and public aid to both public and parochial schools "would not make attendance at either

544 See Archer, The Truth about Shared Time, Educ. Dig., Nov. 1966, at 10, 12.

545 A recent estimate placed $5 \frac{1}{2}$ to 6 million children in Catholic schools; 310,000 in

Protestant schools (mostly Lutheran, also Seventh Day Adventist, Reformed Church and

Mennomite); 50,000 in Jewish day schools. L. PFerfer, supra note 26, at 509-10.

546 Kelley, supra note 223 , at 78.

547 See McGowan v. Maryland, 366 U.S. 420, 462 (1961) (concurring opinion of Frankfurter, J.).

548 See generally Giannella, supra note 199, at 581-90.

549 See U.S. Dep't of Health, Education \& Welfare, supra note 20, at 377-78; National

Catholic Welfare Conference, supra note 37 , at 450.

550 The argument is articulated by P. KAUPER, supra note 5 , at 115 ,

551 Such was the case in Millard v. Board of Educ., 121 IIl. 297, 10 N.E. 669 (1887); Knowlton v. Baumhover, 182 Ia. 691, 166 N.W. 202 (1918) ; Harfst v. Hoegen, 349 Mo. 808, 163 S.W.2d 609 (1942); State ex rel. Pub, School Dist. v. Taylor, 122 Neb. 454, 240 N.W. 573 (1932) ; cf. Berghorn v. Reorganized School Dist., 364 Mo. 121, 260 S.W.2d 573 (1953); Moore v. Board of Educ., 4 Ohio Misc. 257, 212 N.E.2d 833 (1965). 
type of institution any more or less compulsory. ${ }^{9552}$ For both higher and lower levels of education, a public purpose is achieved if the amount of governmental financial assistance does not exceed the value of the secular educational service rendered. ${ }^{553}$

The further argument is made that, since a much higher percentage of students is enrolled in private colleges than in private elementary and secondary schools, the national interest in affording the former financial assistance is nnuch stronger. ${ }^{554}$ But, again, a secular purpose would be served in both instances. ${ }^{555}$ Finally, there are two responses to the argument that "church colleges are not in the business of religious indoctrination, unlike church grammar and high schools." ${ }^{\prime 568}$ First, it may be contradicted by the facts: "[I]n many cliurch-related colleges, religion is just as central a part of the educational program and objectives as it is in parochial schools." ${ }^{.557}$ Second, as has already been slown, the "permeation" issue should not act as a complete bar to aid. ${ }^{568}$

v

\section{EXISTING FEDERAL PROGRAMS}

It has recently been calculated that at present there are more than one hundred federal programs allocating property or funds worth billions of dollars to rehigiously-affiliated institutions, the Department of Health, Education, and Welfare alone aiding close to two thousand churchcounected educational agencies. ${ }^{559}$ Those programs involving the transfer of commodities or equipment for the achievement of specific secular goals, clearly fall within the class of permissibility under the establishment

552 S. Doc. No. 29, 87th Cong., 1st Sess. 69 (1961) (Senator Keating).

553 See State ex rel. Johnson v. Boyd, 217 Ind. 348, 28 N.E.2d 256 (1940). Cf. Wright v. School Dist., 151 Kan. 485, 99 P.2d 737 (1940), where it is obvious that the public aid exceeded the secular value.

554 U.S. Dep't of Health, Education \& Welfare, supya note 20, at 379.

555 Former Senator Keating has pointed out that "it is about as unrealistic to plan a comprehensive aid-to-education bill at the elementary school level which isolates" the "more than 5 million children" attending sectarian schools "as it would be to plan an aid to higher education which ignored ... students attending sectarian colleges." S. Doc. No. 29, supra note 552, at 69. Professor Kauper has noted that the "enrollment" argument "will be weakened as time goes on, since more and more public institutions will have to assume the hon's share of meeting increased demands for college education." P. KAUPER, supra note 5 , at 115 .

556 Note, 61 Nw. UI. REv. 777, 787 (1967). See also U.S. Dep't of Health, Education \& Welfare, supra note 20 , at 380 .

557 Kauper, supra note 35 , at 37.

558 The distinction between colleges on the one hand and grammar and high schools on the other may be relevant under state constitutional provisions. See In re Opinion of the Justices, 214 Mass. 599, 601, 102 N.E. 464, 465 (1913).

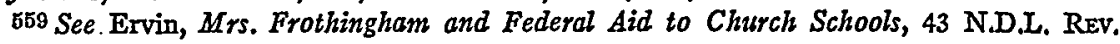
691, 692-93 (1967). 
clause approach proposed herein, as do others affording direct grants for research of a designated nonrehgious nature ${ }^{560}$ and for training personnel for these purposes. ${ }^{61}$ Taxpayers' dollars are plainly not being used for religious purposes. Nor are they so being utilized when public funds are appropriated for the construction or purcliase of facilities or property that will be eniployed for strictly secular purposes ${ }^{562}$ or for the establishment of special programs for the achievement of public ends. ${ }^{563}$

Soniewhat niore suspect, at least in principle, are those plans that grant money to church-affiliated educational institutions for part-time employment assistance to students. ${ }^{54}$ It is possible under such progranis that public funds will be eniployed for strictly rehigious purposes-for example, to pay a student assistant in a religious indoctrination course. But the statutory scheme may protect against this, ${ }^{565}$ and even if it does not, it is highly unlikely, given present realities and those of the foreseeable future in respect to the quantum of public financial assistance, that any establishment clause issue would arise under the proposed rationale. ${ }^{\text {566 }}$

A substantial number of current federal programs pay tuition grants to deserving students. ${ }^{567}$ The possible dangers inherent in this form of governnient monetary assistance have already been discussed. ${ }^{568} \mathrm{But}$,

560 See, e.g., 16 U.S.C. $\$ \$ 581,581 a$ (1964) (agriculture and forestry); 42 U.S.C. $\S \S 1891-93$ (1964) (science and national defense); 42 U.S.C. $\S \S 702(\mathrm{~b}), 712(\mathrm{~b}), 726,729 \mathrm{a}$ (1964) (child and maternal welfare); 42 U.S.C. $\$ 241$ (1964) (health); 42 U.S.C. $\S 1310$ (1964) (public welfare and social security); 42 U.S.C. $\$ 1857$ (1964) (air pollution); 20 U.S.C. $\S \S 331-32$ (1964) (education); 42 U.S.C. \$ 712 (1964) (crippled children); 42 U.S.C. $\S \S 2542-44$ (1964) (juvenile delinquency); 20 U.S.C. 512 (1964) (foreign languages); 20 U.S.C. § 542 (1964) (communications media for educational services); 20 U.S.C. \$ 35c(c) (1964) (vocational education); 29 U.S.C. $\$ 34$ (1964) (rehabilitative medicine); 42 U.S.C. $\S 2473(\mathrm{~b})(5)$ (1964) (aeronautics and space).

561 See, e.g., 10 U.S.C. \$ 4382 (1964) (ROTC); 42 U.S.C. \$\$ 2801-07 (1964) (teachers of illiterates); 42 U.S.C. $\$ 242$ (d) (1964) (nurses); 42 U.S.C. $\$ \$ 282-83$ (1964) (cancer control); 20 U.S.C. $\$ \$ 1031-34$ (1964) (library science); 20 U.S.C. $\$ 611$ (teachers of physically handicapped).

562 See, e.g., 42 U.S.C. $\$ \$ 292-93$ (1964) (medical training); 20 U.S.C. $\$ \$ 701-33$ (Supp. I, 1965) (construction of higher education facilities).

563 See, e.g., 42 U.S.C. $\S 2000 \mathrm{~b}$ (1964) (racial desegregation in education).

564 See, e.g., Economic Opportumity Act of 1964, 42 U.S.C. \$\$ 2751-56 (1964) (workstudy).

56542 U.S.C. $\$ 2754$ (a) (1964) provides "that no such work shall involve the construction, operation, or maintenance of so unuch of any facility used or to be used for sectarian instruction or as a place for religious worship."

566 See text following note 251 supra.

567 See, e.g., 20 U.S.C. $\$ \$ 1061-69$ (Supp. I, 1965) (needy students in higher education); 20 U.S.C. $\$ 511$ (b) (1964) (modern foreign languages); 20 U.S.C. $\$ 464$ (1964) (national defense). See also the "Delaney proposal," H.R. 9803, 87th Cong. 2d Sess. (1962) ( $\$ 20$ annually for each elementary and secondary school child); the "Church proposal," H.R. 4978 \& H.R. 340, 87th Cong., 1st Sess. (1961) (tax benefits for parents of all students). 508 See discussion in text accompanying notes $379-87$ supra. 
again, as a practical matter, there should be no real nonestablishment problems. ${ }^{569}$ In conclusion, whatever the eventual judicial decision concerning the constitutionality of parochial school aid, the federal legislature has long given implicit recognition to its administrative viability, in respect to the rule proposed herein.

\section{CONCLUSTON}

This article has attempted to serve several purposes. One las been to explore the broad scope of the first amendment's mandate that "Congress shall make no law respecting an establishment of religion," from both a traditional and normative perspective, accounting for both historical and contemporary goals. As a rationale for the constitutional adjudication of issues arising under the establishment clause, it suggests that a distinction be drawn between state action for religious and secular purposes and that the first amendment was designed to safeguard personal religious liberty by preventing the government from coercing religious belief and from taxing for religious purposes. The recominended approacl is advanced, however, only as a point of departure. It does not mechanically produce answers, nor is it intended to articulate a "completely coherent system applicable across the board." ${ }^{.570}$ Further, it demands a delicate judicial judgment in close cases, although it would seem that the really difficult applications are more frequently created by imaginative hypotheticals than by the authentic dynamics of government action.

The article's second major purpose has been to propose a constitutional rule for the thorny political issue of governmental financial assistance to parochial education. Specifically, the rule advises that governmental aid to parochial schools is constitutional to the extent that it does not exceed the value of their secular services. Whatever the incidental benefits to religious institutions, the establishment clause should be satisfied by ensuring that government receive secular returns from those institutions commensurate with its financial expenditure.

It is easier to describe briefly what tasks have deliberately been omitted. No reconciliation of the pertinent state, federal, or Supreme Court decisions has been attempted. No prediction as to the outcome of

569 More substantial issues have been presented by the Ordinances for the Northwest and Southwest territories which set aside land grants for the support of religious education and by 18th and 19th century congressional support of religious education of Indians by Christian missionaries. See Costanzo, Federal Aid to Education and Religious Liberty, 36 U. DEr. L.J. 1, 34 (1958). See also 16 U.S.C. \& 479 (1964), authorizing a group of persons residing in the vicinity of national forests to use forest land for the erection of a church. The primary effect of these programs would appear to be the employment of tax funds for religious purposes.

570 Deutsch, Neutrality, Legitimacy, and the Supjeme Court: Some Intersections Between Law and Political Science, 20 Staw. L. Rev. 169, 190 (1968). 
Supreme Court decisions in relevant present and future litigation has been advanced. I have not endeavored to make a carefully balanced appraisal, on the basis of my own bikes or dislikes or those of others, of what is a desirable, feasible or politic legislative course..$^{571}$

If the constitutional rationale advocated will sustain enactments thought unwise by some, they must be reminded that it does not command results thouglit abhorrent by others. For the Court to decide that some parochial school aid may be constitutional does not preclude the legislature from finding that it is unwise or improper. The realm of what is sound and just in this higlily complex and emotionally charged area should remain open for informed debate and expedient resolution so long as the basic underlying freedom guarded by the establishment clause is preserved.

571 See Oaks, supra note 5, at 8. 